\title{
Transuranic Waste Inventory, Characteristics, Generation, and Facility Assessment for Treatment, Storage, and Disposal Alternatives Considered in the U.S. Department of Energy Waste Management Programmatic Environmental Impact Statement
}

by K. Hong, T. Kotek, S. Folga, ${ }^{\star}$ B. Koebnick, Y. Wang, and C. Kaicher

Environmental Assessment Division

Argonne National Laboratory, 9700 South Cass Avenue, Argonne, Illinois 60439

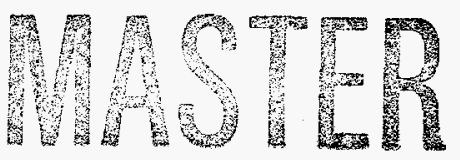

December 1996

Work sponsored by United States Department of Energy,

Assistant Secretary for Environmental Management

"Folga is affiliated with Argonne's Decision and Information Sciences Division. 


\section{DISCLAIMER}

This report was prepared as an account of work sponsored by an agency of the Uinited States Government. Neither the United States Government nor any agency thereof, nor any of their empioyees, make any warranty, express or implied, or assumes any legal liability or responsibility for the accuracy, completeness, or usefulness of any information, apparatus, product, or process disclosed, or represents that its use would not infringe privately owned rights. Reference herein to any specific commercial product, process, or service by trade name, trademark, manufacturer, or otherwise does not necessarily constitute or imply its endorsement, recommendation, or favoring by the United States Government or any agency thereof. The views and opinions of authors expressed herein do not necessarily state or reflect those of the United States Government or any agency thereof. 


\section{DISCLAMMER}

Portions of this document may be illegible in electronic image products. Images are produced from the best available original document. 


\section{CONTENTS}

NOTATION $\ldots \ldots \ldots \ldots \ldots \ldots \ldots \ldots \ldots \ldots \ldots \ldots \ldots \ldots \ldots \ldots \ldots \ldots \ldots \ldots \ldots$

ACKNOWLEDGMENTS $\ldots \ldots \ldots \ldots \ldots \ldots \ldots \ldots \ldots \ldots \ldots \ldots \ldots \ldots \ldots \ldots$

ABSTRACT $\ldots \ldots \ldots \ldots \ldots \ldots \ldots \ldots \ldots \ldots \ldots \ldots \ldots \ldots \ldots \ldots \ldots \ldots$

1 INTRODUCTION $\ldots \ldots \ldots \ldots \ldots \ldots \ldots \ldots \ldots \ldots \ldots \ldots \ldots \ldots \ldots \ldots \ldots \ldots \ldots \ldots$

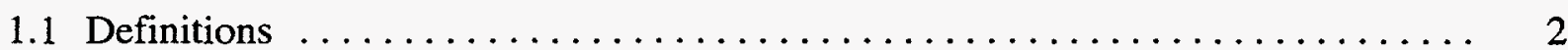

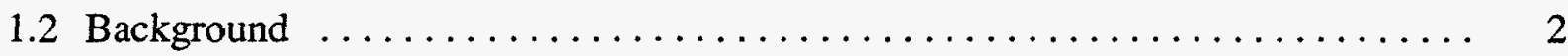

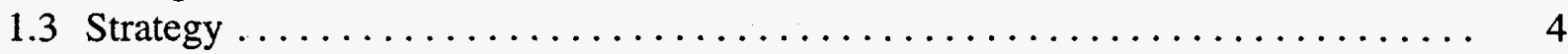

2 TRUW CHARACTERISTICS, INVENTORY, AND GENERATION $\ldots \ldots \ldots \ldots \ldots$

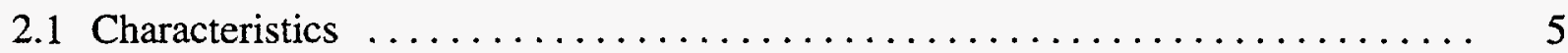

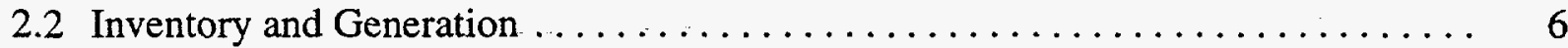

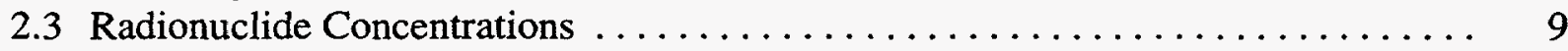

2.4 Hazardous Constituent Concentrations $\ldots \ldots \ldots \ldots \ldots \ldots \ldots \ldots \ldots$

3 TRUW TREATMENT AND STORAGE $\ldots \ldots \ldots \ldots \ldots \ldots \ldots \ldots \ldots \ldots \ldots \ldots$

3.1 Current Storage and Retrieval Operations $\ldots \ldots \ldots \ldots \ldots \ldots \ldots \ldots \ldots \ldots \ldots$

3.2 Levels of Treatment $\ldots \ldots \ldots \ldots \ldots \ldots \ldots \ldots \ldots \ldots \ldots \ldots \ldots \ldots \ldots \ldots$

3.2.1 Treatment to Meet Current WIPP-WAC $\ldots \ldots \ldots \ldots \ldots \ldots \ldots \ldots \ldots$

3.2.2 Treatment to Intermediate Level . . . . . . . . . . . . . . . . 23

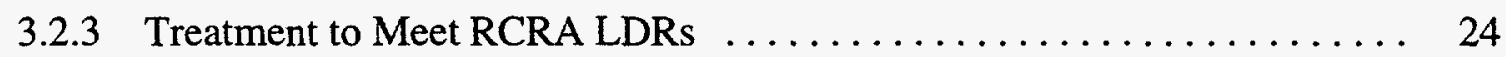

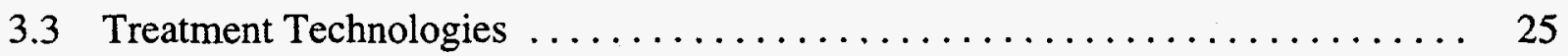

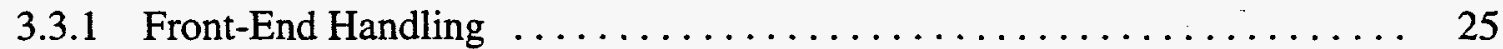



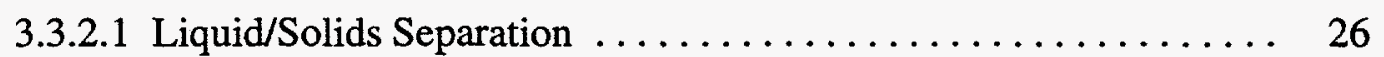

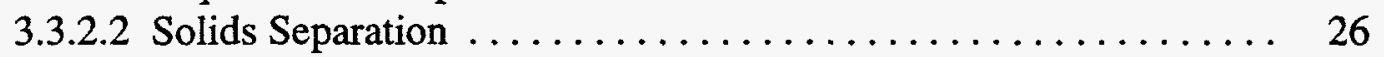

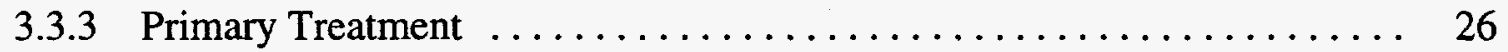

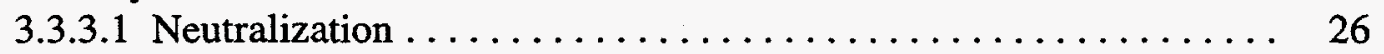

3.3.3.2 Deactivation ........................... 27

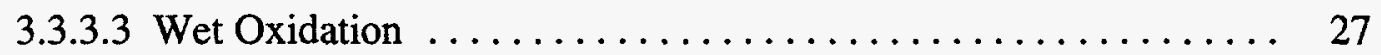

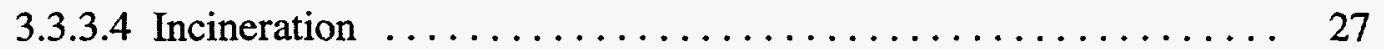

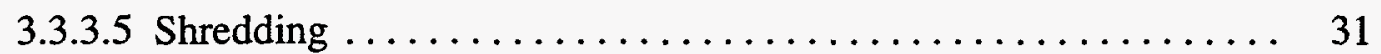

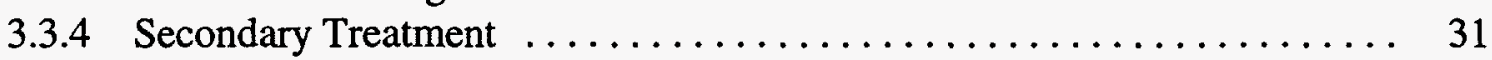

3.3.4.1 Off-Gas Treatment ...................... 32

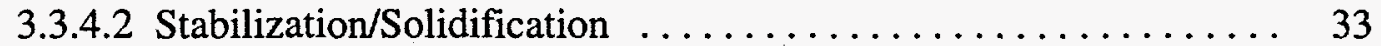

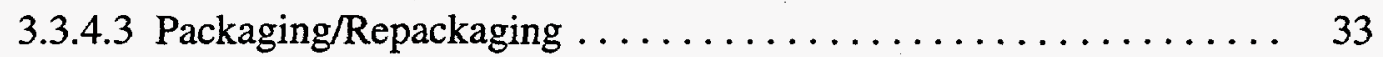



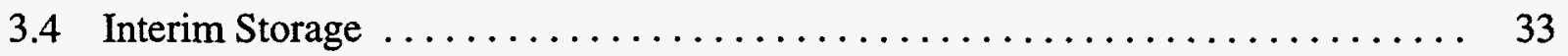




\section{CONTENTS (Cont.)}

4 EXISTING AND PLANNED FACILITIES $\ldots \ldots \ldots \ldots \ldots \ldots \ldots \ldots \ldots \ldots \ldots$

5 TRUW ALTERNATIVES CONSIDERED $\ldots \ldots \ldots \ldots \ldots \ldots \ldots \ldots \ldots \ldots \ldots$

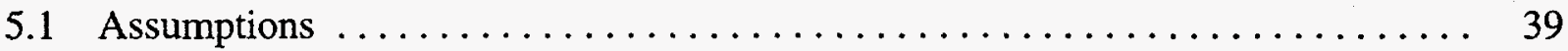

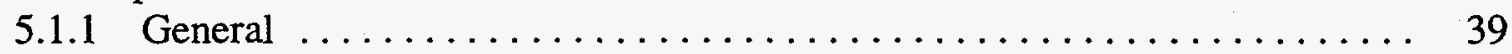

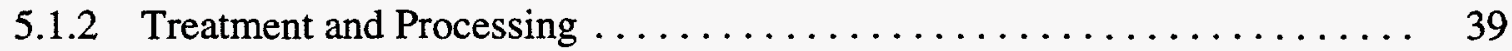

5.1 .3 Waste Volumes and Waste Streams $\ldots \ldots \ldots \ldots \ldots \ldots \ldots \ldots \ldots, 40$

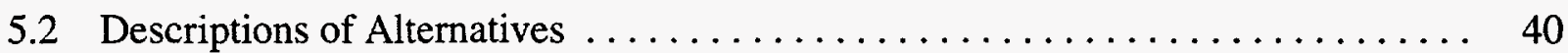

5.2 .1 CH-TRUW Cases $\ldots \ldots \ldots \ldots \ldots \ldots \ldots \ldots \ldots \ldots \ldots \ldots \ldots \ldots \ldots \ldots \ldots \ldots, 42$

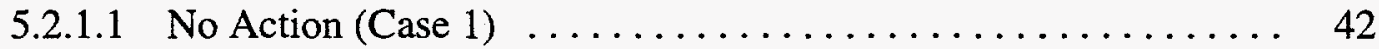

5.2.1.2 Decentralized Treatment to WIPP-WAC at 10 Sites

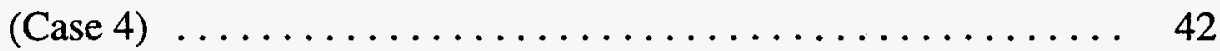

5.2.1.3 Regionalized Intermediate Treatment at Five Sites (Case 5) .... 43

5.2.1.4 Regionalized Treatment to LDRs at Five Sites (Case 6) ...... 43

5.2.1.5 Regionalized Treatment to LDRs at Three Sites (Case 8) ..... 43

5.2.1.6 Centralized Treatment to LDRs at One Site (Case 9) ........ 44

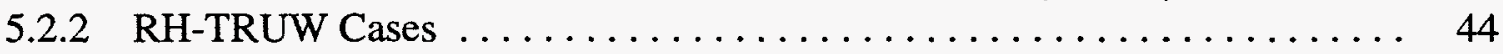

5.2.2.1 No Action (Case 10) $\ldots \ldots \ldots \ldots \ldots \ldots \ldots \ldots \ldots \ldots \ldots \ldots \ldots$

5.2.2.2 Decentralized Treatment to WIPP-WAC 44

5.2.2.3 Regionalized Intermediate Treatment at Two Sites

(Case 14) ........................... 45

5.2.2.4 Regionalized Treatment to LDRs at Two Sites (Case 15) ..... 45

5.2.3 Combined CH- and RH-TRUW Alternatives ................. 45

5.3 Projected Waste Volumes for the Alternatives . . . . . . . . . . . . . . . 46

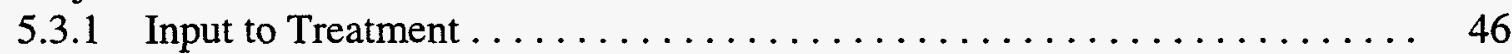

5.3.2 Treatment Products for Disposal $\ldots \ldots \ldots \ldots \ldots \ldots \ldots \ldots \ldots \ldots, 46$

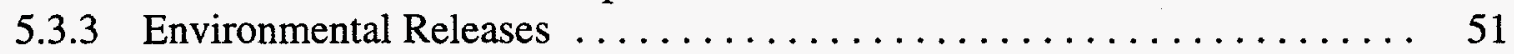

6 APPLICATION OF TRUW SOURCE TERMS $\ldots \ldots \ldots \ldots \ldots \ldots \ldots \ldots \ldots \ldots$

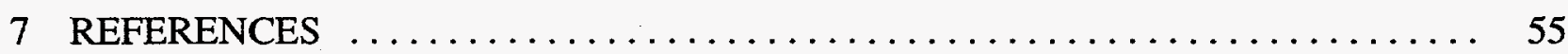

APPENDIX A: Requirements for Disposal of Transuranic Waste at WIPP $\ldots \ldots \ldots \ldots$ A-1

APPENDIX B: Additional Waste Loads and Air Releases for TRUW

Management Alternatives ...................... B-1

APPENDIX C: Unresolved Issues $\ldots \ldots \ldots \ldots \ldots \ldots \ldots \ldots \ldots \ldots \ldots \ldots \ldots \ldots \ldots \ldots \ldots$ 


\section{FIGURES}

3-1 Treatment Trains for Meeting WIPP-WAC $\ldots \ldots \ldots \ldots \ldots \ldots \ldots \ldots \ldots$

3-2 Treatment Trains for Meeting WIPP-WAC and Reducing Gas Generation ....... 20

3-3 Treatment Trains for Meeting WIPP-WAC, Reducing Gas Generation, and Meeting RCRA LDRs

\section{TABLES}

2-1 Estimated CH-TRUW Inventory Volumes and Generation Rates by Waste

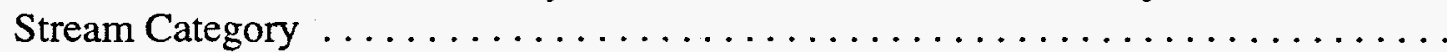

2-2 Estimated RH-TRUW Inventory and Generation Rates by Waste Stream Category . . . . . . . . . . . . . . . . . . . . . . . . . . .

2-3 Radionuclide Concentrations in CH-TRUW at ANL-E $\ldots \ldots \ldots \ldots \ldots \ldots$

2-4 Radionuclide Concentrations in CH-TRUW at Hanford $\ldots \ldots \ldots \ldots \ldots \ldots$

2-5 Radionuclide Concentrations in $\mathrm{CH}-\mathrm{TRUW}$ at INEL $\ldots \ldots \ldots \ldots \ldots \ldots \ldots \ldots$

2-6 Radionuclide Concentrations in CH-TRUW at LANL $\ldots \ldots \ldots \ldots \ldots \ldots \ldots \ldots$

2-7 Radionuclide Concentrations in CH-TRUW at LLNL $\ldots \ldots \ldots \ldots \ldots \ldots \ldots \ldots$

2-8 Radionuclide Concentrations in $\mathrm{CH}-\mathrm{TRUW}$ at Mound $\ldots \ldots \ldots \ldots \ldots \ldots \ldots \ldots$

2-9 Radionuclide Concentrations in CH-TRUW at NTS $\ldots \ldots \ldots \ldots \ldots \ldots \ldots \ldots$

2-10 Radionuclide Concentrations in CH-TRUW at ORR $\ldots \ldots \ldots \ldots \ldots \ldots \ldots \ldots \ldots$

2-11 Radionuclide Concentrations in CH-TRUW at RFETS $\ldots \ldots \ldots \ldots \ldots \ldots \ldots \ldots$

2-12 Radionuclide Concentrations in $\mathrm{CH}-\mathrm{TRUW}$ at SRS $\ldots \ldots \ldots \ldots \ldots \ldots \ldots \ldots \ldots$

2-13 Radionuclide Concentrations in RH-TRUW at ANL-E . . . . . . . . . 12

2-14 Radionuclide Concentrations in RH-TRUW at Hanford $\ldots \ldots \ldots \ldots \ldots \ldots \ldots$

2-15 Radionuclide Concentrations in RH-TRUW at INEL $\ldots \ldots \ldots \ldots \ldots \ldots \ldots$ 


\section{TABLES (Cont.)}

2-16 Radionuclide Concentrations in RH-TRUW at LANL . . . . . . . . . . . . . 14

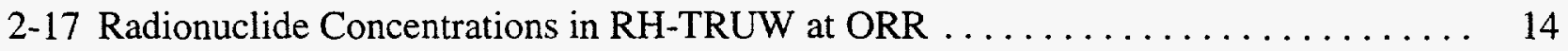

2-18 Radionuclide Concentrations in RH-TRUW at SRS $\ldots \ldots \ldots \ldots \ldots \ldots \ldots$

2-19 Estimated Concentrations of Hazardous Constituents in Mixed

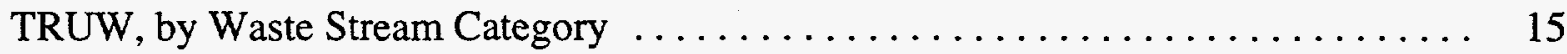

3-1 Unit Operation Parameters for Wet Oxidation $\ldots \ldots \ldots \ldots \ldots \ldots \ldots \ldots \ldots$

3-2 Unit Operation Parameters for Incineration $\ldots \ldots \ldots \ldots \ldots \ldots \ldots \ldots \ldots \ldots \ldots \ldots \ldots$

3-3 Unit Operation Parameters for Solidification $\ldots \ldots \ldots \ldots \ldots \ldots \ldots \ldots \ldots$

4-1 Capacities and Capabilities of Existing and Planned/Approved TRUW

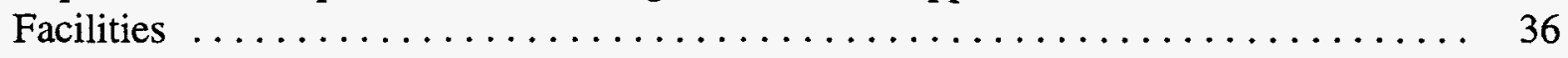

5-1 Projected Annual Newly Generated Waste Volumes by Originating Site for the No Action Alternative $\ldots \ldots \ldots \ldots \ldots \ldots \ldots \ldots \ldots \ldots \ldots \ldots \ldots \ldots \ldots \ldots \ldots$

5-2 Projected Annual Waste Volumes by Originating Site for All Except

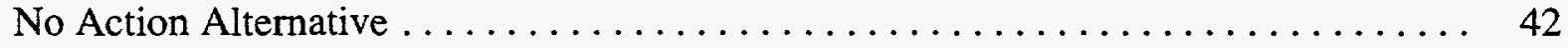

5-3 Treatment Site Waste Volumes for Representative Treatment

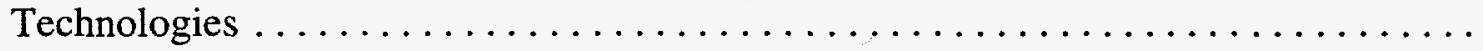

5-4 WIPP Disposal Waste Volumes by Treatment Site for All Except

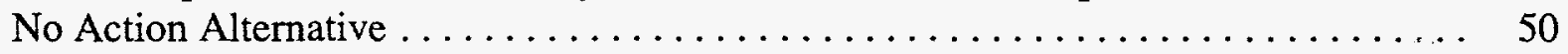

5-5 Projected Environmental Release Profiles for INEL Under the CH Regionalized Case 8 Treatment to LDRs at Three Sites-Incineration . . . . . 51

5-6 Projected Environmental Release Profiles for INEL Under the CH Regionalized Case 8 Treatment to LDRs at Three Sites-Wet Oxidation $\ldots \ldots \ldots \ldots \ldots \ldots \ldots \ldots$

5-7 Projected Environmental Release Profiles for INEL Under the CH Regionalized Case 8 Treatment to LDRs at Three Sites-Solidification . . . . . . . . . . . 


\section{NOTATION}

The following is a list of the acronyms and abbreviations (including units of measure) used in this document.

\section{Acronyms}

ANL-E

ANL-W

CFR

$\mathrm{CH}$

DOE

EPA

ETEC

FR

HEPA

IMWIR

INEL

ITRI

LANL

LBL

LDR

LLNL

LWA

MWIR

NEPA

NMED

NRC

NTS

ORR

O\&S

PCB

PE

PEIS

PGDP

RCRA

RFETS

$\mathrm{RH}$

SARP

SEIS-II
Argonne National Laboratory-East

Argonne National Laboratory-West

Code of Federal Regulations

contact-handled

U.S. Department of Energy

U.S. Environmental Protection Agency

Energy Technology Engineering Center

Federal Register

high-efficiency particulate air

Interim Mixed Waste Inventory Report

Idaho National Engineering Laboratory

Inhalation Toxicology Research Institute

Los Alamos National Laboratory

Lawrence Berkeley Laboratory

Land Disposal Restriction

Lawrence Livermore National Laboratory

Land Withdrawal Act

Mixed Waste Inventory Summary Report

National Environmental Policy Act

New Mexico Environmental Department

U.S. Nuclear Regulatory Commission

Nevada Test Site

Oak Ridge Reservation

operations and safety

polychlorinated biphenyl

plutonium-239 equivalent

Programmatic Environmental Impact Statement

Paducah Gaseous Diffusion Plant

Resource Conservation and Recovery Act

Rocky Flats Environmental Technology Site

remote-handled

Safety Analysis Report for Packaging

Supplemental Environmental Impact Statement II 
SNL-NM

SRS

TRAMPAC

TRUPACT-II

TRUW

TSD

UMC

WAC

WIPP

WIPP BIR-2

WM PEIS

WVDP

\section{Abbreviations}

Am

$\mathrm{Ba}$

${ }^{\circ} \mathrm{C}$

$\mathrm{Ce}$

Cf

Ci

$\mathrm{Cm}$

Co

$\mathrm{Cr}$

Cs

$\mathrm{Eu}$

$\mathrm{Fe}$

$\mathrm{ft}$

$\mathrm{ft}^{3}$

$\mathrm{g}$

$\mathrm{h}$

$\mathrm{kg}$

$\mathrm{m}^{3}$

$\mathrm{mg}$

$\min$

Mn

mrem

$\mathrm{Nb}$

$\mathrm{nCi}$

$\mathrm{Ni}$
Sandia National Laboratories-New Mexico

Savannah River Site

TRUPACT-II Authorized Method for Payload Control

Transuranic Package Transporter-II

transuranic waste

treatment, storage, and disposal

University of Missouri at Columbia

waste acceptance criteria

Waste Isolation Pilot Plant

Waste Isolation Pilot Plant Transuranic Waste Baseline Inventory Report, Revision 2

Waste Management Programmatic Environmental Impact Statement

West Valley Demonstration Project

americium

barium

degree(s) Celsius

cerium

californium

curies

curium

cobalt

chromium

cesium

europium

iron

feet

cubic feet

$\operatorname{gram}(\mathrm{s})$

hour(s)

kilogram(s)

cubic meter(s)

milligram(s)

minute(s)

manganese

milliroentgen-equivalent-man

niobium

nanocurie(s)

nickel 


$\begin{array}{ll}\mathrm{NO}_{x} & \text { nitrogen oxides } \\ \mathrm{Np} & \text { neptunium } \\ \mathrm{Pm} & \text { promethium } \\ \mathrm{Pr} & \text { praseodymium } \\ \mathrm{Pu} & \text { plutonium } \\ \mathrm{Ra} & \text { radium } \\ \mathrm{Rh} & \text { rhodium } \\ \mathrm{Ru} & \text { ruthenium } \\ \mathrm{Sb} & \text { antimony } \\ \mathrm{Sr} & \text { strontium } \\ \mathrm{t} & \text { ton } \\ \mathrm{Tc} & \text { technetium } \\ \mathrm{Th} & \text { thorium } \\ \mathrm{U} & \text { uranium } \\ \mathrm{Y} & \text { yttrium } \\ \mathrm{yr} & \text { year(s) }\end{array}$




\section{ACKNOWLEDGMENTS}

The authors wish to acknowledge the valuable contributions of M. Fisher of META/Berger, P. Drez of Drez Environmental Associates, B. Musgrave of BC Musgrave Inc., and B. Palmer of Los Alamos National Laboratory. 


\title{
TRANSURANIC WASTE INVENTORY, CHARACTERISTICS, GENERATION, AND FACILITY ASSESSMENT FOR TREATMENT, STORAGE, AND DISPOSAL ALTERNATIVES CONSIDERED IN THE U.S. DEPARTMENT OF ENERGY WASTE MANAGEMENT PROGRAMMATIC ENVIRONMENTAL IMPACT STATEMENT
}

by

K. Hong, T. Kotek, S. Folga, B. Koebnick, Y. Wang, and C. Kaicher

\begin{abstract}
Transuranic waste (TRUW) loads and potential contaminant releases at and en route to treatment, storage, and disposal sites in the U.S. Department of Energy (DOE) complex are important considerations in DOE's Waste Management Programmatic Environmental Impact Statement (WM PEIS). Waste loads are determined in part by the level of treatment the waste has undergone and the complexwide configuration of origination, treatment, storage, and disposal sites selected for TRUW management. Other elements that impact waste loads are treatment volumes, waste characteristics, and the unit operation parameters of the treatment technologies. Treatment levels and site configurations have been combined into six TRUW management alternatives for study in the WM PEIS. This supplemental report to the WM PEIS gives the projected waste loads and contaminant release profiles for DOE treatment sites under each of the six TRUW management alternatives. It gives TRUW characteristics and inventories for current DOE generation and storage sites, describes the treatment technologies for three proposed levels of TRUW treatment, and presents the representative unit operation parameters of the treatment technologies. The data presented are primary inputs to developing the costs, health risks, and socioeconomic and environmental impacts of treating, packaging, and shipping TRUW for disposal.
\end{abstract}

\section{INTRODUCTION}

Transuranic waste (TRUW) is primarily generated by research and development activities and defense activities, including weapon stockpile maintenance, plutonium $(\mathrm{Pu})$ recovery during reprocessing of spent nuclear fuel, and weapons manufacturing. TRUW is also retrieved during environmental restoration and decontamination and decommissioning projects. TRUW includes 
some isotopes of neptunium $(\mathrm{Np})$, plutonium $(\mathrm{Pu})$, americium $(\mathrm{Am})$, curium $(\mathrm{Cm})$, and californium (Cf).

\subsection{DEFINITIONS}

The U.S. Department of Energy (DOE) defines TRUW as, "Without regard to source or form, waste that is contaminated with alpha-emitting transuranium radionuclides with half-lives greater than 20 years, and concentrations greater than $100 \mathrm{nCi} / \mathrm{g}$ at the time of assay" (DOE 1988). This lower limit is interpreted as being per gram of waste matrix; it does not include the weights of added external shielding or waste containers (including any rigid liners) (DOE 1991a). Department of Energy Order 5820.2A states, "Heads of Field Elements can determine that other alphacontaminated waste, peculiar to a specific site, must be managed as transuranic waste" (DOE 1988). As such, wastes containing uranium-233 (U-233) and radium-226 (Ra-226) may be managed as TRUW. For example, waste managed as TRUW at the West Valley Demonstration Project (WVDP) includes radioactive waste with concentrations of transuranic radionuclides as low as $10 \mathrm{nCi} / \mathrm{g}$. The term "TRUW" in this document refers to all material meeting the definition of TRUW regardless of whether it contains hazardous constituents, whereas "mixed TRUW" is used when specifically referring to wastes that may be subject to Land Disposal Restrictions (LDRs) under the Resource Conservation and Recovery Act (RCRA) (40 CFR 268).

By definition, packaged TRUW with a surface dose rate $\leq 200 \mathrm{mrem} / \mathrm{h}$ is categorized as contact-handled TRUW (CH-TRUW). Packaged TRUW with a surface dose rate of $>200 \mathrm{mrem} / \mathrm{h}$ is defined as remote-handled (RH-TRUW).

\subsection{BACKGROUND}

The Waste Isolation Pilot Plant (WIPP), a TRUW management facility operated by DOE near Carlsbad, New Mexico, is currently identified as the permanent disposal site for DOE-generated TRUW. The mission of WIPP, as established by Congress under Public Law 96-164 is to serve as a research and development facility for the safe disposal of TRUW. To ensure that TRUW can be safely disposed at WIPP, DOE has developed waste acceptance criteria (WAC) that waste generators and storage sites must meet before shipping waste to WIPP. These Waste Isolation Pilot Plant waste acceptance criteria (DOE 1991a), which define waste forms and establish waste certification and transportation package requirements, as well as requirements for handling radioactive and hazardous waste were taken into account during development of the alternatives analyzed in the Waste Management (WM) Programmatic Environmental Impact Statement (PEIS) (DOE 1996a). Since the Draft WM PEIS was prepared, DOE has revised the WIPP-WAC (DOE 1996d). Revision 5 eliminated WAC that applied only to waste to be used in underground-test-phase experiments at WIPP, which were canceled, and rewrote the remaining requirements to make the document easier 
to use. Some additional requirements were added, including limits on volatile organic compounds and polychlorinated biphenyls (PCBs). In general, the changes to the WIPP-WAC were minor, and the revised WIPP-WAC are slightiy more restrictive than the previous version. Under the circumstances, the analysis based on Revision 4 of WIPP-WAC is assumed to be adequate for the purposes of bounding the impacts that might be expected from packaging and treating waste to meet Revision 5 of WIPP-WAC. More information about requirements for disposal of TRUW at WIPP may be found in Appendix A.

Before 1970, all DOE-generated TRUW was disposed at DOE facilities in shallow landfilltype configurations. In 1970, the Atomic Energy Commission, DOE's predecessor, concluded that waste containing long-lived alpha-emitting radionuclides should be more isolated from the environment. The concentration level in the TRUW definition was changed from greater than $10 \mathrm{nCi} / \mathrm{g}$ to greater than $100 \mathrm{nCi} / \mathrm{g}$ in 1982 (DOE 1982), which resulted in reclassification of about 40 percent of the post-1970 TRUW as low-level waste. The reclassification of waste formerly managed as TRUW is a continuing action that complicates retrieval operations and definition of waste derived from environmental restoration.

Thus, all TRUW generated since the early 1970s has been segregated from other waste types and placed in temporary storage pending shipment and final disposal in a permanent geologic repository (DOE 1992a). This waste is considered environmental restoration waste and will be managed in accordance with the Comprehensive Environmental Response, Compensation, and Liability Act (CERCLA). The TRUW generated since 1970 is described as retrievably stored and is the primary focus of this study.

The TRUW generated before 1970 is known as "buried TRUW." The environmental consequences of Environmental Restoration are addressed in the PEIS as a connected action according to National Environmental Policy Act (NEPA) definitions, which means that they are determined separately and then combined with the consequences of the DOE Waste Management activities. TRUW loads, the waste management alternatives selected for analysis, and an analysis of possible impacts on Waste Management decisions for waste generated by Environmental Restoration activities are presented in Appendix B of the WM PEIS and are summarized in Section 8.16, "Environmental-Restoration-Transferred Waste," in Volume I of the WM PEIS.

Not all of the sites across the DOE Complex possess post-1970 TRUW, but those that do store it retrievably. Initially, retrievable storage involved putting the waste in containers, of various sizes and compositions, and placing the containers in trenches, pits, vaults, caissons, or on hard pads. The containers were usually positioned close to each other and then covered with wood, plastic, and finally soil. These waste storage configurations are referred to as "bermed" storage. A more recent storage method involves placing TRUW in above-ground storage facilities, making inspection, maintenance, repair, packing of containers, and retrieval easier than in the case of bermed storage units-while ensuring compliance with RCRA requirements. 
CH-TRUW is typically contained in 55-gallon $\left(0.21 \mathrm{~m}^{3}\right)$ drums or in boxes of various sizes. RH-TRUW is typically contained in drums, canisters, or concrete casks.

\subsection{STRATEGY}

DOE's current strategy is to treat mixed TRUW as necessary to (1) meet the safety and health requirements for transport, or (2) to meet waste acceptance criteria for disposal at WIPP. This assumes that DOE will succeed in obtaining all necessary permits and approvals from the appropriate regulatory agencies, including a no migration determination pursuant to 40 CFR 268.6, Land Disposal Restrictions (DOE 1990), and concurrence by the State of New Mexico Environment Department (NMED) for disposal of mixed TRUW at WIPP. The WIPP Land Withdrawal Act (LWA) amendments contained in the 1997 Defense Authorization Act, however, render the RCRA LDRs inapplicable to waste to be disposed of at WIPP.

This determination would eliminate the need to treat the waste to the extent that would be necessary if LDRs were to be met. Regardless of whether a no migration determination is obtained, the final criteria necessary to achieve compliance with the standards for long-term performance for WIPP are expected to be more restrictive than the current criteria. This expectation is based on the negotiations process with the States and on the DOE's assessment of the performance of the WIPP repository after disposal of TRUW. Therefore, the PEIS analysis of TRUW management alternatives considers: (1) minimal treatment to meet the current WIPP waste acceptance criteria, (2) intermediate treatment to reduce gas generation potential by waste in the repository, and (3) treatment to meet LDRs so that the full range of impacts of treating TRUW will be adequately covered in the analysis.

This report describes the currently identified TRUW volumes that must be treated and disposed, the conceptual flow diagrams and technologies used to analyze consequences of the alternatives, the existing and planned facilities, and the projected waste loads, which are input to the TRUW alternatives analyzed in the WM PEIS. The waste volumes to be treated and disposed are used as inputs to the calculations used to analyze costs, transportation, accidents, health risks, environmental impacts, and socioeconomic impacts. The conceptual flow diagrams and technologies are the basis for estimating costs of design and construction of new facilities, and operation, maintenance, decontamination, and decommissioning of all facilities required for treating and packaging TRUW for disposal. The conceptual flow diagrams and technologies are also the basis for calculating the environmental releases used in the impacts analyses. The cost reports are an input to the socioeconomic analysis, and the health risk analysis is considered in the socioeconomic analysis. The existing and planned facilities are the baseline for determining the number and sizes of new facilities to be modeled in the analysis. 


\section{TRUW CHARACTERISTICS, INVENTORY, AND GENERATION}

This section describes TRUW physical and chemical characteristics and presents retrievably stored TRUW inventory data and projected TRUW generation rates. It also provides information about concentrations of radionuclides and hazardous constituents contained in TRUW. These data are direct input to the calculations used to analyze costs, transportation, accidents, health risks, and socioeconomic impacts. Environmental restoration TRUW loads used in the PEIS are included in Appendix B of the WM PEIS.

\subsection{CHARACTERISTICS}

The characteristics of TRUW, which originates from hundreds of waste streams, have been obtained by DOE through process knowledge supplemented by $\mathrm{x}$-ray examination, radioassay, analysis of the gas in drum headspace, and opening and sampling of a limited number of waste containers to verify the physical and chemical properties of their contents.

Most TRUW is in the form of solid waste (for example, contaminated protective clothing, paper trash, rags, glassware, tools, and machine parts), but some is in liquid/sludge form. Depending on its physical and chemical properties, the TRUW that appears in various waste streams can be grouped into categories. This grouping of TRUW facilitates efficient treatment consideration in the PEIS. Specific treatment trains that include a series of generic treatment technologies have been postulated for each category; these trains are identified in the conceptual treatment flow diagrams in Section 3.2.

The following list includes the waste stream category names with their numerical designations that are used in the tables and graphics of this document.

Aqueous liquids (1000)

Organic liquids (2000)

Solid process residues $(3000)$

- organic sludges/particulates

- inorganic sludges/particulates

- cemented solids

Soils (4000)

- soil with less than $50 \%$ debris

Debris (5000)

- organic debris

- inorganic debris

- heterogeneous debris
Special (6000)

- lab packs with metals

- lab packs without metals

Inherently hazardous (7000)

- reactive metals

- elemental lead

- batteries (lead, acid, cadmium)

Unknown (requires further characterization; handle on case-by-case basis) (8000) 
It is estimated that about 60 percent of TRUW is mixed waste, containing both radioactive and hazardous constituents (DOE 1996b). Some of the radioactive constituents of TRUW are cocontaminants other than transuranic isotopes. Examples of mixed waste are radionuclidecontaminated liquids, waste treatment sludge containing spent solvents, discarded debris contaminated with solvents and radioactive material, and discarded contaminated lead shielding. Some transuranic mixed waste is commingled with PCBs. For the purposes of the WM PEIS, all TRUW is analyzed as if it were mixed waste.

\subsection{INVENTORY AND GENERATION}

The largest volumes of TRUW are generated or stored at 10 major DOE sites-Argonne National Laboratory-East (ANL-E), the Hanford Site (Hanford), Idaho National Engineering Laboratory (INEL), Lawrence Livermore National Laboratory (LLNL), Los Alamos National Laboratory (LANL), the Mound Plant, the Nevada Test Site (NTS), the Oak Ridge Reservation (ORR), Rocky Flats Environmental Technology Site (RFETS), and the Savannah River Site (SRS).

The principal generators of smaller volumes of TRUW are the Energy Technology Engineering Center (ETEC), Lawrence Berkeley Laboratory (LBL), the Paducah Gaseous Diffusion Plant (PGDP), Sandia National Laboratories/Inhalation Toxicology Research Institute (SNL/ITRI), the University of Missouri at Columbia (UMC), and the West Valley Demonstration Project (WVDP).

At the end of 1994 , DOE was responsible for approximately $66,000 \mathrm{~m}^{3}$ of retrievably stored CH-TRUW and about $1,700 \mathrm{~m}^{3}$ of retrievably stored RH-TRUW (DOE 1995a, 1995b). Approximately 96 percent of the existing CH-TRUW and RH-TRUW is stored at Hanford, INEL, LANL, ORR, and SRS.

Tables 2-1 and 2-2 provide estimated inventory and generation data for CH-TRUW and RH-TRUW, respectively, at their generation/storage sites. The data were derived from the higher of the values given in DOE's Interim Mixed Waste Inventory Report (IMWIR) (DOE 1993) and Integrated Data Base for 1992 (DOE 1992a). Updated information on waste volumes was used for two sites. Updated data for TRUW were taken from two sources: the Mixed Waste Inventory Summary Report (MWIR 95) (DOE 1995a) and the Waste Isolation Pilot Plant Transuranic Waste Baseline Inventory Report, Revision 2 (WIPP BIR-2) (DOE 1995b), with most of the new information taken from MWIR 95. MWIR 95 contains information on waste as it currently exists, specifying treatability groups, and therefore can be considered directly applicable to the WM PEIS analyses for calculating impacts from treatment. The information on as-generated waste forms is readily available from MWIR 95 but is not readily extracted from the WIPP BIR-2 data. A portion of the WIPP BIR-2 waste loads reflect some level of treatment because they are intended to represent the volume of the final waste form considered to be disposed of at WIPP. The WIPP BIR-2 was used 
TABLE 2-1 Estimated CH-TRUW Inventory Volumes and Generation Rates by Waste Stream Category ${ }^{a}$

\begin{tabular}{|c|c|c|c|}
\hline Site & $\begin{array}{c}\text { Waste Stream } \\
\text { Category }\end{array}$ & Inventory ${ }^{\mathrm{c}}\left(\mathrm{m}^{3}\right)$ & Generation $\left(\mathrm{m}^{3} / \mathrm{yr}\right)$ \\
\hline \multirow[t]{2}{*}{ ANL-E } & 1000 & 12 & 44 \\
\hline & 3000 & 3 & 3 \\
\hline ETEC & 7000 & 0.02 & 0 \\
\hline \multirow[t]{6}{*}{ Hanford } & 3000 & 0.2 & 0 \\
\hline & 4000 & 113 & 330 \\
\hline & 5000 & 12,080 & 134 \\
\hline & 6000 & 2.3 & 0.4 \\
\hline & 7000 & 1.9 & 0 \\
\hline & 8000 & 82 & 1,197 \\
\hline \multirow{3}{*}{$\operatorname{INEL}^{\mathrm{d}}$} & 3000 & 6,473 & 2 \\
\hline & 5000 & 31,622 & 12 \\
\hline & 7000 & 0.4 & 0 \\
\hline \multirow{3}{*}{ LANL } & 3000 & 3,168 & 8 \\
\hline & 5000 & 4,921 & 117 \\
\hline & 7000 & 110 & 1 \\
\hline LBL & $5000^{e}$ & 0.8 & 0.01 \\
\hline \multirow{3}{*}{ LLNL } & 1000 & 63 & 23 \\
\hline & 2000 & 32 & 12 \\
\hline & 5000 & 105 & 39 \\
\hline Mound & 3000 & 165 & 0 \\
\hline NTS & $\begin{array}{l}7000 \\
5000\end{array}$ & $\begin{array}{c}90 \\
612\end{array}$ & $\begin{array}{c}60 \\
0\end{array}$ \\
\hline ORR & 7000 & 670 & 18 \\
\hline \multirow[t]{2}{*}{ PGDP } & 1000 & 8 & 0 \\
\hline & 3000 & 6 & 0 \\
\hline \multirow{4}{*}{ RFETS } & 1000 & 15 & 1 \\
\hline & 3000 & 647 & 43 \\
\hline & 5000 & 658 & 191 \\
\hline & 7000 & 161 & 3 \\
\hline & 5000 & 1 & 0 \\
\hline \multirow{3}{*}{ SRS } & 2000 & 0.1 & 0 \\
\hline & 3000 & 0.1 & 0 \\
\hline & 5000 & 5,136 & 576 \\
\hline UMC & $5000^{e}$ & 0.1 & 2 \\
\hline WVDP & 7000 & 0.5 & 0 \\
\hline
\end{tabular}

a The total CH-TRUW inventory across all sites is $66,000 \mathrm{~m}^{3}$. The total CH-TRUW generation rate across all sites is $2,350 \mathrm{~m}^{3} / \mathrm{yr}$. This table does not include every small site (however, these 16 sites account for more than $99 \%$ of the current and projected TRUW inventory), nor does it include environmental restoration or decontamination/decommissioning streams.

b See Section 2.1 .

c Derived from DOE 1992a, 1993, 1995a, and 1995b.

d Includes TRUW from Argonne National Laboratory-West.

e Waste stream category is not available, but is assumed to be 5000 for calculation purposes. 
TABLE 2-2 Estimated RH-TRUW Inventory and Generation Rates by Waste Stream Category ${ }^{\mathbf{a}}$

\begin{tabular}{lccc}
\hline Site & $\begin{array}{c}\text { Waste Stream } \\
\text { Category }\end{array}$ & $\begin{array}{c}\text { Inventory } \\
\left(\mathrm{m}^{3}\right)\end{array}$ & $\begin{array}{c}\text { Projected } \\
\text { Generation Rate } \\
\left(\mathrm{m}^{3} / \mathrm{yr}\right)\end{array}$ \\
\hline ANL-E & $5000^{\mathrm{d}}$ & 0 & 17 \\
Hanford & 5000 & 199 & 976 \\
& 7000 & 2.7 & 3 \\
INEL & 8000 & 0 & 97 \\
& 3000 & 2 & 18 \\
LANL & 5000 & 106 & 5 \\
ORR & 7000 & 0.4 & 2 \\
& $5000^{\mathrm{d}}$ & 79 & 0.5 \\
SRS & 3000 & 1,142 & 14 \\
\hline
\end{tabular}

a The total RH-TRUW inventory across all sites is $1,700 \mathrm{~m}^{3}$; the total RH-TRUW generation rate across all sites is $850 \mathrm{~m}^{3} / \mathrm{yr}$.

b See Section 2.1 .

c Derived from DOE 1992a, 1993, 1995a, and 1995b.

d Waste stream category is not available, but is assumed to be 5000 for calculation purposes.

e Includes TRUW from Argonne National Laboratory-West. 
for its radiological profiles and for more definitive waste operation estimates in the out years that are not available from MWIR 95.

\subsection{RADIONUCLIDE CONCENTRATIONS}

Tables 2-3 through 2-12 list radionuclide concentrations in CH-TRUW at 10 major DOE sites. Some radionuclides listed are not transuranic; however, they are included because they are cocontaminants. For evaluation purposes, the radiological profiles for generators of smaller volumes, such as ETEC, LBL, PGDP, SNL, UMC, and WVDP are assumed to be the same as for LLNL (Table 2-7).

Tables 2-13 through 2-18 give the radionuclide concentrations of RH-TRUW for the DOE sites with this material.

Because radionuclide concentrations are not reported by waste stream in the source documents (DOE 1992a, 1993, 1995a), the concentration of a radionuclide at a site is defined as the ratio of the total activity of the transuranic radionuclide in the TRUW at the site to the total volume of TRUW at the site. To perform the analysis, total activity in a drum or a canister can be assumed by taking the product of the concentration and the volume of the drum $\left(0.21 \mathrm{~m}^{3}\right)$ or canister $\left(0.89 \mathrm{~m}^{3}\right)$. For evaluation purposes, the radionuclide concentrations at a site are assumed to be waste stream-independent. This approach is similar to that applied within the WIPP Supplemental Environmental Impact Statement II (SEIS-II) (DOE 1996b).

\subsection{HAZARDOUS CONSTITUENT CONCENTRATIONS}

Table 2-19 provides estimated concentration ranges for hazardous constituents in mixed TRUW by waste stream category. Because of the current lack of similar detailed process knowledge from the other DOE sites with TRUW, these concentration ranges were estimated based on knowledge of the waste-generating processes at RFETS, which has the most detailed process knowledge information on hazardous constituents available in the DOE system. The geometric means of the ranges will be used in calculating waste loads for each TRUW management alternative (Section 5). For evaluation purposes, the concentrations are assumed to be site-independent. 
TABLE 2-3 Radionuclide Concentrations in CH-TRUW at ANL-E

\begin{tabular}{lc}
\hline & $\begin{array}{c}\text { Activity Density } \\
\left(\mathrm{Ci} / \mathrm{m}^{3}\right)\end{array}$ \\
\hline Radionuclide & \\
$\mathrm{U}-235$ & $2.4 \times 10^{-6}$ \\
$\mathrm{U}-238$ & $6.8 \times 10^{-7}$ \\
$\mathrm{Pu}-239$ & $7.3 \times 10^{-1}$ \\
$\mathrm{Pu}-240$ & $1.6 \times 10^{-1}$ \\
$\mathrm{Pu}-241$ & 4.4 \\
\hline
\end{tabular}

Source: DOE 1991b.

TABLE 2-4 Radionuclide Concentrations in CH-TRUW at Hanford

\begin{tabular}{lc}
\hline Radionuclide & $\begin{array}{c}\text { Activity Density } \\
\left(\mathrm{Ci} / \mathrm{m}^{3}\right)\end{array}$ \\
\hline C-14 & $1.3 \times 10^{-4}$ \\
Sr-90 & $5.6 \times 10^{-2}$ \\
Y-90 & $5.6 \times 10^{-2}$ \\
Cs-137 & $5.6 \times 10^{-2}$ \\
Ba-137m & $5.3 \times 10^{-2}$ \\
Th-231 & $1.4 \times 10^{-4}$ \\
Th-234 & $4.8 \times 10^{-4}$ \\
U-233 & $6.5 \times 10^{-3}$ \\
U-235 & $4.4 \times 10^{-3}$ \\
U-238 & $4.9 \times 10^{-4}$ \\
Pa-234m & $4.8 \times 10^{-4}$ \\
Np-237 & $2.2 \times 10^{-5}$ \\
Pu-238 & 6.6 \\
Pu-239 & 2.1 \\
Pu-240 & $5.0 \times 10^{-1}$ \\
Pu-241 & 3.1 \\
Pu-242 & $3.1 \times 10^{-5}$ \\
Am-241 & $3.9 \times 10^{-1}$ \\
Cm-244 & $5.6 \times 10^{-3}$ \\
Cm-245 & $1.4 \times 10^{-3}$ \\
Cf-252 & $2.9 \times 10^{-4}$ \\
\hline
\end{tabular}

TABLE 2-5 Radionuclide Concentrations in CH-TRUW at INEL

\begin{tabular}{lc}
\hline & $\begin{array}{c}\text { Activity Density } \\
\left(\mathrm{Ci} / \mathrm{m}^{3}\right)\end{array}$ \\
\hline Radionuclide & $1.4 \times 10^{-2}$ \\
Sr-90 & $1.8 \times 10^{-5}$ \\
Cs-137 & $1.8 \times 10^{-2}$ \\
Ce-144 & $1.3 \times 10^{-4}$ \\
Pm-147 & $5.8 \times 10^{-2}$ \\
Th-232 & $7.6 \times 10^{-6}$ \\
U-233 & $2.1 \times 10^{-2}$ \\
U-235 & $3.8 \times 10^{-6}$ \\
U-238 & $3.2 \times 10^{-6}$ \\
Np-237 & $1.5 \times 10^{-5}$ \\
Pu-238 & 1.5 \\
Pu-239 & $9.3 \times 10^{-1}$ \\
Pu-240 & $2.3 \times 10^{-1}$ \\
Pu-241 & 6.7 \\
Pu-242 & $2.4 \times 10^{-5}$ \\
Am-241 & 2.0 \\
Cm-244 & $2.6 \times 10^{-2}$ \\
Cf-252 & $1.5 \times 10^{-6}$ \\
\hline
\end{tabular}

Source: DOE 1991b.

Source: DOE $1995 b$. 
TABLE 2-6 Radionuclide Concentrations in CH-TRUW at I.ANL

\begin{tabular}{lc}
\hline & $\begin{array}{c}\text { Activity Density } \\
\left(\mathrm{Ci} / \mathrm{m}^{3}\right)\end{array}$ \\
\hline Radionuclide & $2.9 \times 10^{-2}$ \\
Sr-90 & $2.9 \times 10^{-2}$ \\
Y-90 & $2.2 \times 10^{-2}$ \\
$\mathrm{Cs}-137$ & $1.9 \times 10^{-2}$ \\
$\mathrm{Ba}-137 \mathrm{~m}$ & $2.2 \times 10^{-2}$ \\
$\mathrm{Pm}-147$ & $4.9 \times 10^{-6}$ \\
$\mathrm{U}-235$ & $2.7 \times 10^{-5}$ \\
$\mathrm{U}-238$ & $1.6 \times 10^{1}$ \\
$\mathrm{Pu}-238$ & 6.1 \\
$\mathrm{Pu}-239$ & 2 \\
$\mathrm{Pu}-240$ & $8.5 \times 10^{1}$ \\
$\mathrm{Pu}-241$ & $2.5 \times 10^{-4}$ \\
$\mathrm{Pu}-242$ & $1.8 \times 10^{1}$ \\
$\mathrm{Am}-241$ & \\
\hline
\end{tabular}

Source: DOE $1991 \mathrm{~b}$.

TABLE 2-7 Radionuclide Concentrations in CH-TRUW at LLNL

\begin{tabular}{lc}
\hline & $\begin{array}{c}\text { Activity Density } \\
\left(\mathrm{Ci} / \mathrm{m}^{3}\right)\end{array}$ \\
\hline Radionuclide & \\
$\mathrm{Pu}-238$ & $8.3 \times 10^{-2}$ \\
$\mathrm{Pu}-239$ & 1.7 \\
$\mathrm{Pu}-240$ & $5.0 \times 10^{-1}$ \\
$\mathrm{Pu}-241$ & $1.2 \times 10^{1}$ \\
$\mathrm{Pu}-242$ & $5.3 \times 10^{-5}$ \\
$\mathrm{Am}-241$ & $5.5 \times 10^{-1}$ \\
\hline
\end{tabular}

TABLE 2-8 Radionuclide Concentrations in CH-TRUW at Mound

\begin{tabular}{lc}
\hline & $\begin{array}{c}\text { Activity Density } \\
\left(\mathrm{Ci} / \mathrm{m}^{3}\right)\end{array}$ \\
\hline Radionuclide & \\
$\mathrm{Pu}-238$ & 8.5 \\
$\mathrm{Pu}-239$ & $6.3 \times 10^{-3}$ \\
$\mathrm{Pu}-240$ & $4.4 \times 10^{-3}$ \\
\hline
\end{tabular}

Source: DOE 1991b.

TABLE 2-9 Radionuclide Concentrations in CH-TRUW at NTS

Activity Density

\begin{tabular}{lc} 
Radionuclide & $\left(\mathrm{Ci} / \mathrm{m}^{3}\right)$ \\
\hline & \\
$\mathrm{Pu}-238$ & $5.3 \times 10^{-3}$ \\
$\mathrm{Pu}-239$ & $1.3 \times 10^{-1}$ \\
$\mathrm{Pu}-240$ & $2.9 \times 10^{-2}$ \\
$\mathrm{Pu}-241$ & 1.2 \\
$\mathrm{Pu}-242$ & $2.0 \times 10^{-6}$ \\
\hline
\end{tabular}

Source: DOE $1991 b$.

Source: DOE 1991b. 
TABLE 2-10 Radionuclide Concentrations in CH-TRUW at ORR

\begin{tabular}{lc}
\hline & $\begin{array}{c}\text { Activity Density } \\
\left(\mathrm{Ci} / \mathrm{m}^{3}\right)\end{array}$ \\
\hline Radionuclide & $7.1 \times 10^{-6}$ \\
$\mathrm{U}-232$ & 1.3 \\
$\mathrm{U}-235$ & $4.5 \times 10^{-5}$ \\
$\mathrm{U}-238$ & $6.9 \times 10^{-5}$ \\
$\mathrm{~Np}-237$ & $1.4 \times 10^{-2}$ \\
$\mathrm{Pu}-238$ & $2.0 \times 10^{1}$ \\
$\mathrm{Pu}-239$ & 6.8 \\
$\mathrm{Pu}-240$ & 5.4 \\
$\mathrm{Pu}-241$ & $1.0 \times 10^{2}$ \\
$\mathrm{Am}-241$ & 1.3 \\
$\mathrm{Cm}-244$ & $2.0 \times 10^{1}$ \\
$\mathrm{Cf}-252$ & $3.8 \times 10^{-1}$ \\
\hline
\end{tabular}

Source: DOE 1991b.

TABLE 2-11 Radionuclide Concentrations in CH-TRUW at RFETS

\begin{tabular}{lc}
\hline & $\begin{array}{c}\text { Activity Density } \\
\left(\mathrm{Ci} / \mathrm{m}^{3}\right)\end{array}$ \\
\hline Radionuclide & $1.6 \times 10^{-7}$ \\
$\mathrm{U}-235$ & $6.1 \times 10^{-2}$ \\
$\mathrm{Pu}-238$ & 1.7 \\
$\mathrm{Pu}-239$ & $4.1 \times 10^{-1}$ \\
$\mathrm{Pu}-240$ & $1.1 \times 10^{1}$ \\
$\mathrm{Pu}-241$ & $1.2 \times 10^{-5}$ \\
$\mathrm{Pu}-242$ & 1.8 \\
$\mathrm{Am}-241$ & \\
\hline
\end{tabular}

Source: DOE 1991b.
TABLE 2-12 Radionuclide Concentrations in CH-TRUW at SRS

\begin{tabular}{lc}
\hline & $\begin{array}{c}\text { Activity Density } \\
\left(\mathrm{Ci} / \mathrm{m}^{3}\right)\end{array}$ \\
\hline Radionuclide & $3.2 \times 10^{1}$ \\
Sr-90 & $3.2 \times 10^{1}$ \\
Y-90 & $3.5 \times 10^{1}$ \\
Cs-137 & $3.3 \times 10^{1}$ \\
Ba-137m & $7.3 \times 10^{-4}$ \\
Eu-155 & $2.1 \times 10^{-3}$ \\
U-233 & $6.4 \times 10^{-3}$ \\
U-234 & $7.3 \times 10^{-4}$ \\
U-237 & $5.7 \times 10^{-4}$ \\
Np-237 & $2.3 \times 10^{-1}$ \\
Pu-238 & 1.7 \\
Pu-239 & $8.3 \times 10^{-1}$ \\
Pu-240 & $2.3 \times 10^{1}$ \\
Pu-241 & $2.5 \times 10^{-5}$ \\
Pu-242 & $9.6 \times 10^{-1}$ \\
Am-241 & \\
\hline
\end{tabular}

Source: DOE 1995b.

TABLE 2-13 Radionuclide Concentrations in RH-TRUW at ANL-E

\begin{tabular}{lc}
\hline Radionuclide & $\begin{array}{c}\text { Activity Density } \\
\left(\mathrm{Ci} / \mathrm{m}^{3}\right)\end{array}$ \\
\hline & \\
Cs-137 & 9.2 \\
$\mathrm{U}-238$ & $1.1 \times 10^{-1}$ \\
Pu-239 & $1.5 \times 10^{-1}$ \\
Pu-240 & $1.1 \times 10^{-1}$ \\
Pu-241 & 1.4 \\
\hline
\end{tabular}

Source: DOE 1991b. 
TABLE 2-14 Radionuclide

Concentrations in RH-TRUW at

Hanford

\begin{tabular}{|c|c|}
\hline Radionuclide & $\begin{array}{l}\text { Activity Density } \\
\left(\mathrm{Ci} / \mathrm{m}^{3}\right)\end{array}$ \\
\hline Co-60 & 1.7 \\
\hline Sr-90 & $3.2 \times 10^{1}$ \\
\hline$Y-90$ & $3.2 \times 10^{1}$ \\
\hline Cs -137 & $3.5 \times 10^{1}$ \\
\hline $\mathrm{Ba}-137 \mathrm{~m}$ & $3.3 \times 10^{1}$ \\
\hline Th-231 & $7.3 \times 10^{-4}$ \\
\hline $\mathrm{Pa}-234 \mathrm{~m}$ & $5.1 \times 10^{-5}$ \\
\hline U-233 & $2.1 \times 10^{-3}$ \\
\hline U-234 & $6.4 \times 10^{-3}$ \\
\hline$U-235$ & $7.3 \times 10^{-4}$ \\
\hline U-237 & $5.7 \times 10^{-4}$ \\
\hline$U-238$ & $5.1 \times 10^{-5}$ \\
\hline Pu-238 & $2.3 \times 10^{-1}$ \\
\hline Pu-239 & 1.7 \\
\hline $\mathrm{Pu}-240$ & $8.3 \times 10^{-1}$ \\
\hline $\mathrm{Pu}-241$ & $2.3 \times 10^{1}$ \\
\hline $\mathrm{Pu}-242$ & $2.5 \times 10^{-5}$ \\
\hline Am-241 & $9.6 \times 10^{-1}$ \\
\hline
\end{tabular}

Source: DOE 1995b.
TABLE 2-15 Radionuclide Concentrations in RH-TRUW at INEL

\begin{tabular}{|c|c|}
\hline Radionuclide & $\begin{array}{l}\text { Activity Density } \\
\left(\mathrm{Ci} / \mathrm{m}^{3}\right)\end{array}$ \\
\hline $\mathrm{Cr}-51$ & $1.7 \times 10^{-2}$ \\
\hline $\mathrm{Mn}-54$ & $1.1 \times 10^{3}$ \\
\hline $\mathrm{Co}-58$ & $2.8 \times 10^{-1}$ \\
\hline $\mathrm{Fe}-59$ & $1.7 \times 10^{-2}$ \\
\hline $\mathrm{Co}-60$ & $1.1 \times 10^{-1}$ \\
\hline $\mathrm{Ni}-63$ & 1.0 \\
\hline Sr-90 & $1.6 \times 10^{2}$ \\
\hline$Y-90$ & $5.2 \times 10^{-1}$ \\
\hline $\mathrm{Nb}-95$ & $1.8 \times 10^{-3}$ \\
\hline Tc-99 & $3.8 \times 10^{-4}$ \\
\hline $\mathrm{Ru}-106$ & $4.1 \times 10^{1}$ \\
\hline Rh-106 & $3.2 \times 10^{-3}$ \\
\hline Sb-125 & $1.5 \times 10^{-2}$ \\
\hline Cs-134 & 2.3 \\
\hline Cs-137 & $4.5 \times 10^{1}$ \\
\hline $\mathrm{Ba}-137 \mathrm{~m}$ & $4.1 \times 10^{-1}$ \\
\hline Ce-144 & 9.7 \\
\hline Pr-144 & $3.8 \times 10^{-2}$ \\
\hline Pm-147 & $5.2 \times 10^{2}$ \\
\hline Eu-154 & $3.8 \times 10^{-3}$ \\
\hline Eu-155 & $1.9 \times 10^{-3}$ \\
\hline Th-232 & $1.7 \times 10^{-7}$ \\
\hline U-233 & $5.9 \times 10^{-4}$ \\
\hline U-235 & $1.3 \times 10^{-3}$ \\
\hline U-236 & $1.2 \times 10^{-5}$ \\
\hline U-238 & $1.4 \times 10^{-4}$ \\
\hline Np-237 & $1.3 \times 10^{-5}$ \\
\hline $\mathrm{Pu}-238$ & $1.9 \times 10^{-1}$ \\
\hline $\mathrm{Pu}-239$ & $7.6 \times 10^{-2}$ \\
\hline $\mathrm{Pu}-240$ & $3.4 \times 10^{-1}$ \\
\hline $\mathrm{Pu}-241$ & $1.9 \times 10^{2}$ \\
\hline
\end{tabular}

Source: DOE $1991 b$. 
TABLE 2-16 Radionuclide

Concentrations in RH-TRUW at

LANL

\begin{tabular}{lc}
\hline & $\begin{array}{c}\text { Activity Density } \\
\left(\mathrm{Ci} / \mathrm{m}^{3}\right)\end{array}$ \\
\hline Radionuclide & \\
Sr-90 & $2.4 \times 10^{1}$ \\
Y-90 & $2.4 \times 10^{1}$ \\
Cs-137 & $1.8 \times 10^{1}$ \\
Ba-137m & $1.6 \times 10^{1}$ \\
Pm-147 & $1.8 \times 10^{1}$ \\
U-235 & $1.3 \times 10^{-4}$ \\
U-238 & $1.2 \times 10^{-5}$ \\
Pu-238 & $9.2 \times 10^{-2}$ \\
Pu-239 & 1.1 \\
Pu-240 & $3.5 \times 10^{-1}$ \\
Pu-241 & $1.5 \times 10^{1}$ \\
Pu-242 & $6.8 \times 10^{-5}$ \\
\hline
\end{tabular}

Source: DOE 1991b.

TABLE 2-18 Radionuclide Concentrations in RH-TRUW at SRS

\begin{tabular}{ll}
\hline & $\begin{array}{c}\text { Activity Density } \\
\left(\mathrm{Ci} / \mathrm{m}^{3}\right)\end{array}$ \\
\hline Radionuclide & \\
$\mathrm{H}-3$ & $2.7 \times 10^{-6}$ \\
$\mathrm{Sr}-90$ & $1.3 \times 10^{-3}$ \\
$\mathrm{Y}-90$ & $1.3 \times 10^{-3}$ \\
$\mathrm{Cs}-137$ & $1.3 \times 10^{-3}$ \\
$\mathrm{Ba}-137 \mathrm{~m}$ & $1.3 \times 10^{-3}$ \\
$\mathrm{Pm}-147$ & $2.6 \times 10^{-4}$ \\
$\mathrm{Pu}-238$ & $1.7 \times 10^{-3}$ \\
$\mathrm{Pu}-239$ & $2.1 \times 10^{-6}$ \\
$\mathrm{Pu}-240$ & $9.9 \times 10^{-8}$ \\
$\mathrm{Am}-241$ & $1.3 \times 10^{-5}$ \\
$\mathrm{Cm}-244$ & $9.1 \times 10^{-4}$ \\
\hline
\end{tabular}

TABLE 2-17 Radionuclide Concentrations in RH-TRUW at ORR

\begin{tabular}{lc}
\hline & $\begin{array}{c}\text { Activity Density } \\
\left(\mathrm{Ci} / \mathrm{m}^{3}\right)\end{array}$ \\
\hline Radionuclide & \\
Co-60 & 2.3 \\
Sr-90 & $8.0 \times 10^{1}$ \\
Cs-137 & $8.5 \times 10^{1}$ \\
Eu-152 & $1.1 \times 10^{1}$ \\
Eu-154 & 6.6 \\
Th-232 & $2.6 \times 10^{-3}$ \\
U-233 & $9.4 \times 10^{-2}$ \\
U-235 & $2.4 \times 10^{-7}$ \\
U-238 & $4.7 \times 10^{-7}$ \\
Np-237 & $9.0 \times 10^{-5}$ \\
Pu-238 & $3.8 \times 10^{-1}$ \\
Pu-239 & $1.6 \times 10^{-1}$ \\
Pu-240 & $2.1 \times 10^{-4}$ \\
Pu-241 & $5.2 \times 10^{-6}$ \\
Am-241 & $3.1 \times 10^{-2}$ \\
Cm-244 & 2.0 \\
Cf-252 & $4.1 \times 10^{-2}$ \\
\hline
\end{tabular}

Source: DOE 1991b.

Source: DOE 1995b. 
TABLE 2-19 Estimated Concentrations (mg/kg) of Hazardous Constituents in Mixed TRUW, by Waste Stream Category ${ }^{\mathrm{a}}$

\begin{tabular}{|c|c|c|c|c|c|c|c|c|c|c|}
\hline \multirow{3}{*}{$\begin{array}{c}\text { Hazardous } \\
\text { Constituent }\end{array}$} & \multirow{2}{*}{\multicolumn{2}{|c|}{$\begin{array}{c}\text { Aqueous } \\
\text { Liquids }(1000) \\
\end{array}$}} & \multirow{2}{*}{\multicolumn{2}{|c|}{$\begin{array}{c}\text { Organic Liquids } \\
(2000)\end{array}$}} & \multicolumn{6}{|c|}{ Solid Process Residues (3000) } \\
\hline & & & & & \multicolumn{2}{|c|}{$\begin{array}{c}\text { Organic } \\
\text { Sludge }\end{array}$} & \multicolumn{2}{|c|}{$\begin{array}{c}\text { Cemented } \\
\text { Solids }\end{array}$} & \multicolumn{2}{|c|}{$\begin{array}{c}\text { Inorganic } \\
\text { Sludge }\end{array}$} \\
\hline & Conen. & Mean & Concn. & Mean & Concn. & Mean & Concn. & Mean & Conen. & Mean \\
\hline 1,1,1-Trichloroethane & 20 & 20 & 150,000 & 150,000 & 150,000 & 150,000 & $20-200$ & 63 & $20-200$ & 63 \\
\hline Carbon tetrachloride & 15 & 15 & 50,000 & 50,000 & 50,000 & 50,000 & $15-25$ & 19 & $15-25$ & 19 \\
\hline $\begin{array}{l}\text { 1,1,2-Trichloro- } \\
\text { 1,2,2-trifluoroethane }\end{array}$ & 20 & 20 & 50,000 & 50,000 & 50,000 & 50,000 & $20-200$ & 63 & $20-200$ & 63 \\
\hline Methylene chloride & $5-700$ & 59 & 0 & 0 & 0 & 0 & $5-700$ & 59 & $5-700$ & 59 \\
\hline Methyl alcohol & $5-25$ & 11 & 0 & 0 & 0 & 0 & $5-25$ & 11 & $5-25$ & 11 \\
\hline Butyl alcohol & $5-10$ & 7 & 0 & 0 & 0 & 0 & $5-10$ & 7 & $5-10$ & 7 \\
\hline Xylene & 10 & 10 & 0 & 0 & 0 & 0 & $10-50$ & 22 & $10-50$ & 22 \\
\hline Toluene & 10 & 10 & 0 & 0 & 0 & 0 & 10 & 10 & 10 & 10 \\
\hline Ethyl benzene & 10 & 10 & 0 & 0 & 0 & 0 & 10 & 10 & 10 & 10 \\
\hline Cadmium & $5-10$ & 7 & 0 & 0 & 0 & 0 & $5-10$ & 7 & $5-10$ & 7 \\
\hline Lead & 10 & 10 & 0 & 0 & 0 & 0 & $0-400$ & 63 & $10-400$ & 63 \\
\hline Mercury & 0 & 0 & 0 & 0 & 0 & 0 & 0 & 0 & 0 & 0 \\
\hline
\end{tabular}

(Table continued on next page.) 
TABLE 2-19 (Cont.)

\begin{tabular}{|c|c|c|c|c|c|c|c|c|c|c|}
\hline \multirow{3}{*}{$\begin{array}{l}\text { Hazardous } \\
\text { Constituent }\end{array}$} & \multirow{2}{*}{\multicolumn{2}{|c|}{$\begin{array}{c}\text { Aqueous } \\
\text { Liquids }(1000)\end{array}$}} & \multirow{2}{*}{\multicolumn{2}{|c|}{$\begin{array}{c}\text { Organic Liquids } \\
(2000)\end{array}$}} & \multicolumn{6}{|c|}{ Solid Process Residues ( 3000 ) } \\
\hline & & & & & \multicolumn{2}{|c|}{$\begin{array}{l}\text { Organic } \\
\text { Sludge } \\
\end{array}$} & \multicolumn{2}{|c|}{$\begin{array}{c}\text { Cemented } \\
\text { Solids } \\
\end{array}$} & \multicolumn{2}{|c|}{$\begin{array}{c}\text { Inorganic } \\
\text { Sludge }\end{array}$} \\
\hline & Conen. & Mean & Concn. & Mean & Conen. & Mean & Concn. & Mean & Concn. & Mean \\
\hline 1,1,1-Trichloroethane & $20-200$ & 63 & $150-2,000$ & 548 & $1-2,000$ & 45 & 15 & 15 & $1-900$ & 30 \\
\hline Carbon tetrachloride & $15-25$ & 19 & $150-750$ & 335 & $1-900$ & 30 & 10 & 10 & $1-100$ & 10 \\
\hline $\begin{array}{l}\text { 1,1,2-Trichloro- } \\
\text { 1,2,2-trifluoroethane }\end{array}$ & $20-200$ & 63 & $100-2,500$ & 500 & $1-8,000$ & 89 & 75 & 75 & $1-8,000$ & 89 \\
\hline Methylene chloride & $5-700$ & 59 & $50-1,000$ & 224 & $50-1,000$ & 224 & 200 & 200 & 200 & 200 \\
\hline Methyl alcohol & $5-25$ & 11 & 0 & 0 & 0 & 0 & 0 & 0 & 0 & 0 \\
\hline Butyl alcohol & $5-10$ & 7 & 0 & 0 & 0 & 0 & 0 & 0 & 0 & 0 \\
\hline Xylene & $10-50$ & 22 & 0 & 0 & 0 & 0 & 0 & 0 & 0 & 0 \\
\hline Toluene & 10 & 10 & 0 & 0 & 0 & 0 & 0 & 0 & 0 & 0 \\
\hline Ethyl benzene & 10 & 10 & 0 & 0 & 0 & 0 & 0 & 0 & 0 & 0 \\
\hline Cadmium & $5-10$ & 7 & 0 & 0 & $5-250,000$ & 1,118 & 0 & 0 & 0 & 0 \\
\hline Lead & $10-400$ & 63 & $5-60,000$ & 548 & $10->10$ & 10 & $\begin{array}{r}49,000- \\
250,000\end{array}$ & 110,680 & $\begin{array}{l}49,000 \\
250,000\end{array}$ & 110,680 \\
\hline Mercury & 0 & 0 & 0 & 0 & 0 & 0 & 0 & 0 & $10->10$ & 10 \\
\hline
\end{tabular}

a Values derived from knowledge of the waste-generating process at RFETS (Drez 1993). 


\section{TRUW TREATMENT AND STORAGE}

A conceptual process for managing TRUW includes (1) retrieving from storage and transporting to a processing/treatment facility; (2) sorting, treating as appropriate, packaging, and certifying as acceptable to WIPP in the treatment facility; (3) interim storing of certified waste; and (4) transporting to WIPP for final disposal. If DOE is granted a no-migration variance in accordance with 40 CFR 268.6 (indicating that hazardous constituents will not migrate offsite), then sites will be required to treat TRUW as necessary to meet transportation, safety, and health considerations, such as repackaging, to meet the current WIPP-WAC would be necessary; however, an intermediate level of treatment may be necessary to reduce the potential for gas generation in WIPP to meet a future, more stringent WIPP-WAC. The WIPP LWA amendments contained in the 1997 Defense Authorization Act render the RCRA LDRs inappropriate for WIPP disposal. However a range of treatment options are being considered within the draft WIPP SEIS-II (DOE 1996b) to assess whether to dispose of the TRUW at WIPP.

This section describes feasible technologies used in the PEIS analysis for TRUW treatment and storage and presents conceptual flow diagrams for minimum, intermediate, and more extensive levels of treatment. The values of representative unit operation parameters, such as quantities of radionuclides released as compared with throughput, are provided for various treatment technologies. These values are part of the input used in calculating the treatment waste loads for each of the TRUW management alternatives considered in the WM PEIS. These data are the basis for calculating the costs of treating and packaging TRUW for disposal, calculating the health risks, performing the facilities accident analysis, and determining the environmental releases needed for the environmental impacts analysis. (See Section 5.1.3 for information about the projected waste volumes for the TRUW alternatives).

\subsection{CURRENT STORAGE AND RETRIEVAL OPERATIONS}

TRUW is stored in different types of containers, including steel drums, wooden boxes, and concrete culverts. Most of these drums and boxes are stacked on asphalt pads and then covered with plywood and several feet of soil.

No significant emissions of radioactive and hazardous constituents are expected during current storage and retrieval operations, if storage containers remain intact. A waste container could, however, corrode during storage, and the damaged container would allow releases to occur during retrieval operations. Preliminary estimates indicate that about 72 percent of TRUW retrievably stored in drums has been stored for 10 years or more and that up to 30 percent of these drums may be badly deteriorated. Based on experience from waste container sampling programs at INEL, it is has been assumed that only 0.01 percent of the gaseous hazardous and radioactive constituents and 0.0001 
percent of the hazardous and radioactive particulates stored in the drum would be released and become airborne from breached containers during retrieval operations (DOE 1992b).

To minimize potential risk from these emissions, retrieval operations can be performed within an enclosed structure in which slightly below atmospheric pressure is maintained. To reduce particulate emissions, ventilated air could be discharged through two high-efficiency particulate air (HEPA) filter trains in series.

\subsection{LEVELS OF TREATMENT}

Various treatment technologies would be combined as appropriate to treat TRUW waste streams. Waste stream-specific treatment trains for the three levels of TRUW treatment presented above are identified in Figures 3-1 through 3-3. As shown in the figures, the principal TRUW waste streams include solid process residues (3000), debris wastes (5000), and, to a lesser degree, aqueous liquids (1000), and organic liquids (2000). Soil waste streams (4000) would primarily result from environmental restoration activities. Special (6000), inherently hazardous (7000), and unknown (8000) wastes are not shown on the flow diagrams because they are set aside to await special processing. The majority of streams 6000 to 8000 are associated with unknown wastes (8000) for which extensive characterization is required prior to treatment.

Descriptions of the treatments shown are provided in Section 3.3.

\subsubsection{Treatment to Meet Current WIPP-WAC}

Treatment of wastes according to the flow diagram in Figure 3-1 provides compliance with the current WIPP-WAC under a RCRA no migration variance (40 CFR 268.6). Waste streams that comply with the current WIPP-WAC are not treated further.

Specific waste streams are handled as described below.

Aqueous Liquids (1000): Aqueous liquids are stabilized by grouting (mixing the waste with Portland cement to form a concrete-like mass).

Organic Liquids (2000): Organic liquids are stabilized by organic solidification (use of a binding agent, such as calcium silicates, to form a solid).

Solid Process Residues, Soils, and Debris (3000-5000): All solid process residues, soils, and debris are examined for compliance with WIPP certification requirements. Noncompliant items may be aqueous liquids (these may require treatment for ignitable, corrosive, or reactive 


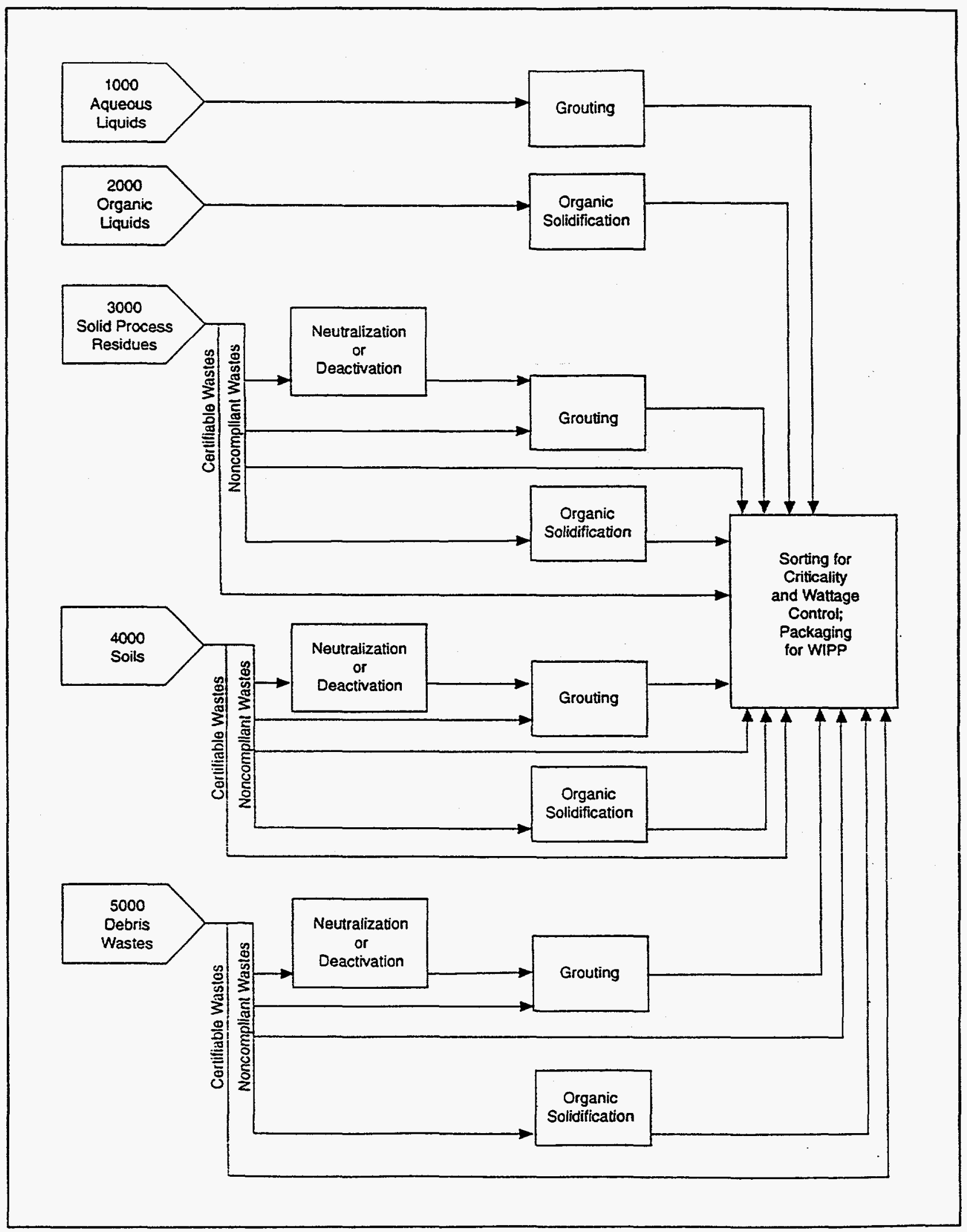

FIGURE 3-1 Treatment Trains for Meeting WIPP-WAC 

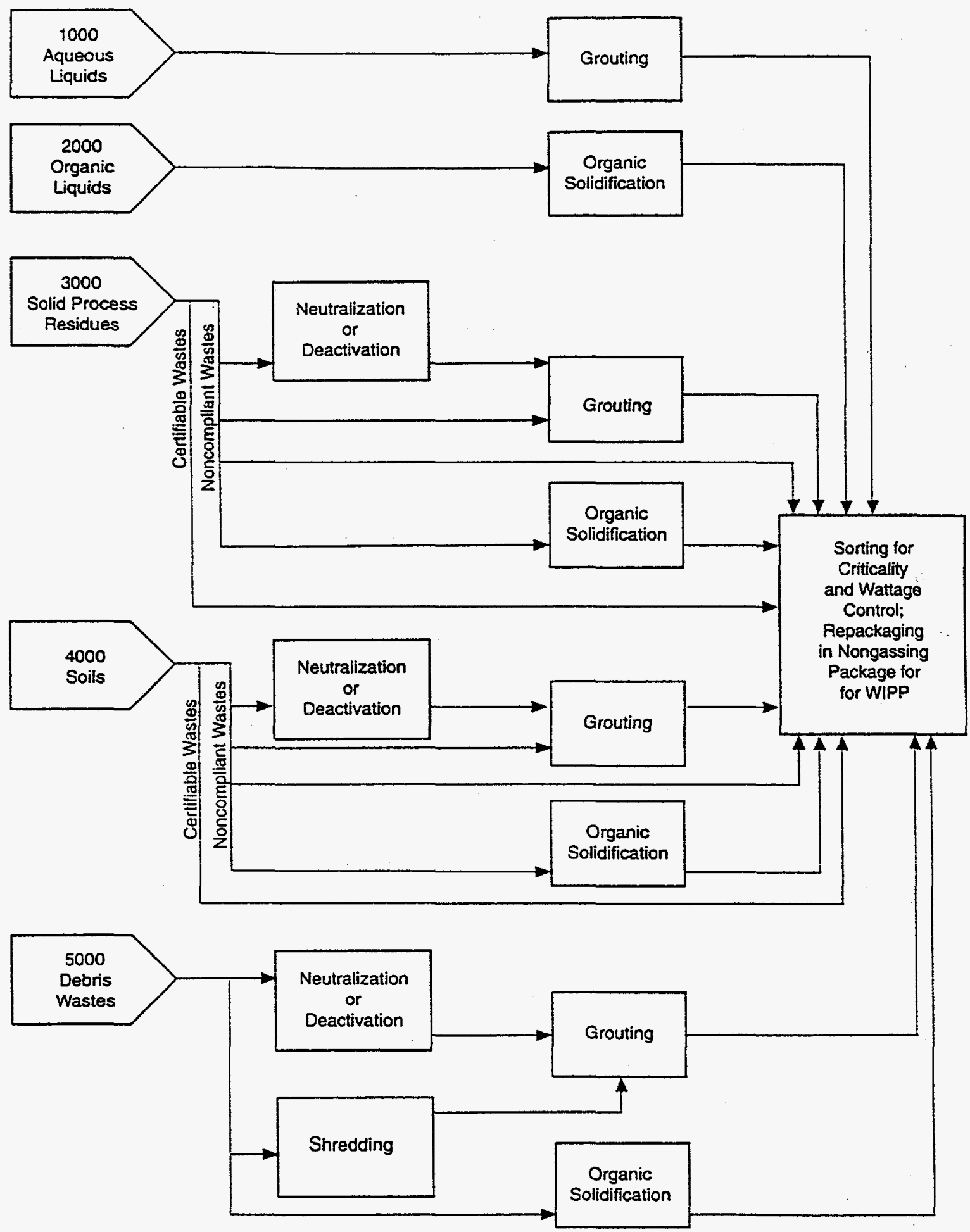

FIGURE 3-2 Treatment Trains for Meeting WIPP-WAC and Reducing Gas Generation 


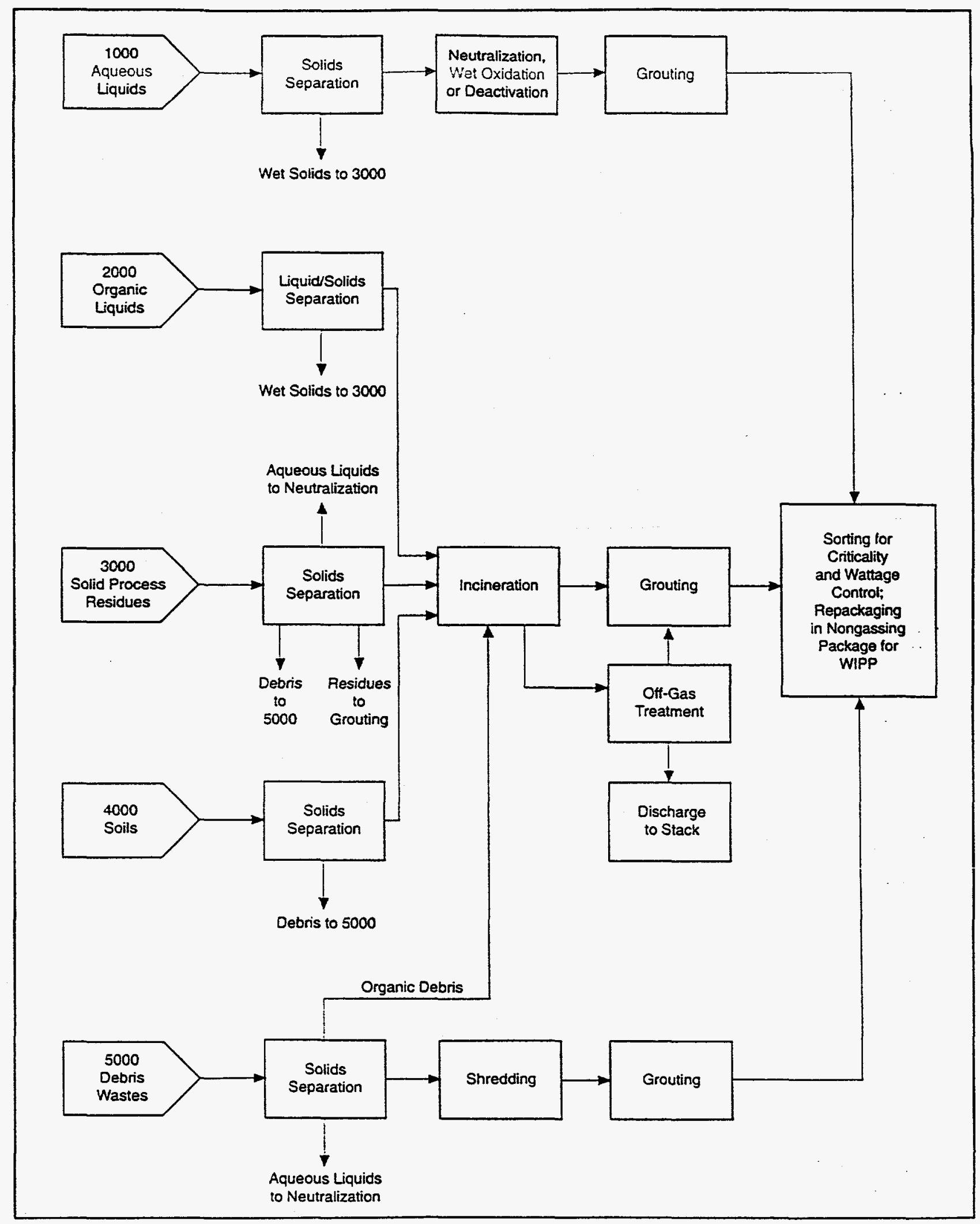

FIGURE 3-3 Treatment Trains for Meeting WIPP-WAC, Reducing Gas Generation, and Meeting RCRA LDRs 
characteristics) and organic liquids, unsolidified sludges, particulates, debris, and compressed gases. Treatment and repackaging for WIPP-WAC compliance provides the capability to sort and repackage packages that exceed the WIPP-WAC plutonium- 239 fissile-gram equivalent criticality limit and the wattage limit for the Transuranic Package Transporter-II (TRUPACT-II) transport containers.

For nuclear criticality purposes, the fissile or fissionable radionuclide content within a 55-gallon drum containing CH-TRUW shall be no greater than 200 g plutonium-239 equivalent (PE). The plutonium-239 fissile gram equivalent within a single 55-gallon drum was calculated using the following formula:

$$
\begin{aligned}
& \mathrm{Pu}-239 \text { equivalent }(\mathrm{g})=[\text { Drum activity } \mathrm{Pu}-239(\mathrm{Ci})] /\left(6.2 \times 10^{-2} \mathrm{Ci} / \mathrm{g}\right)+ \\
& \text { [Drum activity } \mathrm{U}-235(\mathrm{Ci})] /\left(2.2 \times 10^{-6} \mathrm{Ci} / \mathrm{g}\right)+ \\
& \text { [Drum activity } \mathrm{U}-233(\mathrm{Ci})] /\left(9.7 \times 10^{-3} \mathrm{Ci} / \mathrm{g}\right)+ \\
& (45 / 20) \times[\text { Drum activity } \mathrm{Pu}-241(\mathrm{Ci})] /\left(1.0 \times 10^{2} \mathrm{Ci} / \mathrm{g}\right)+ \\
& (450 / 30) \times[\text { Drum activity } \mathrm{Cm}-245(\mathrm{Ci})] /\left(1.7 \times 10^{-1} \mathrm{Ci} / \mathrm{g}\right)
\end{aligned}
$$

For RH-TRUW, the fissile limit for a single canister (equivalent to three 55-gallon drums in volume) is $600 \mathrm{~g}$ PE.

The thermal power (i.e., the heat-generating capacity) of RH-TRUW is limited to $300 \mathrm{~W}$ per canister. The thermal power within a single RH-TRUW canister was calculated by the following equation:

Thermal power $(\mathrm{W})=\sum_{i=1}^{n}[$ Activity of radionuclide $i(\mathrm{Ci})] \times$

[Specific power of $i(\mathrm{~W} / \mathrm{Ci})$ ]

with the specific power for a given radionuclide taken from the Integrated Data Base for 1992 (DOE 1992a).

The volume of waste contained within a given CH-TRUW 55-gallon drum or RH-TRUW canister was decreased in the event that either of the above criteria were exceeded. Certifiable compliant wastes are sent directly for packaging and certification.

Solid Process Residues (3000): After being sorted for noncompliant items, corrosive and reactive liquids are neutralized and deactivated, then grouted with cement. Organic liquids are solidified with calcium silicates. Noncompliant powders and particulates are immobilized with cement to meet WAC limits. Sludges are sent to the repackaging unit for criticality and wattage control. All treated materials are then packaged and certified for shipment to WIPP. 
Soils (4000): No mixed TRUW soil waste streams are listed in the IMWIR (DOE 1993). Some soils will likely be present in other waste streams, especially the debris waste streams. For WIPP-WAC-compliant treatment, the only concern with soils is the potential presence of radioactive particulates, which, if above WAC limits, would be grouted before packaging for disposal. The schematic in Figure 3-1 represents a generic treatment process for TRUW-contaminated soils from environmental restoration activities.

Debris Wastes (5000): The treatment process for waste stream category 5000 is essentially the same as that for waste stream 3000 except that debris wastes are sent to the repackaging unit for criticality and wattage control before being packaged and certified for shipment to WIPP.

\subsubsection{Treatment to Intermediate Level}

Figure 3-2 illustrates a representative conceptual process for an increased level of treatment that would primarily reduce the potential gas generation rate from waste disposed at WIPP. (As an example, plutonium reacts with water and acids in a process called radiolysis, generating hydrogen gas. Plastics and other organic materials are also decomposed by radiolysis.) This method, however, substantially increases the volume of waste. The final WIPP-WAC may require a different treatment process; however, this conceptual process is presented to assess the impact of treating TRUW to less extensive a degree than to RCRA LDRs. This reduced gas generation is achieved by shredding and grouting unsegregated debris and placing all wastes in final containers made from materials that are not expected to generate significant gas when disposed at WIPP. Specific waste streams are handled as described below.

Aqueous Liquids: Aqueous liquids are stabilized by cementatious stabilization (i.e., grouting).

Organic Liquids: Organic liquids are stabilized by organic solidification.

Solid Process Residues, Soils, and Debris: All solid process residues, soils, and debris are examined for compliance with WIPP certification requirements. Noncompliant items may be aqueous liquids (these may require treatment for ignitable, corrosive, or reactive characteristics), and organic liquids, unsolidified sludges, particulates, debris, and compressed gases. Treatment and repackaging for WIPP-WAC compliance provides the capability to sort and repackage packages that exceed the WIPP-WAC Pu-239 fissile-gram equivalent criticality limit and the wattage limit for the TRUPACT-II transport containers. Certifiable compliant wastes are sent directly for packaging and certification.

Solid Process Residues: After being sorted for noncompliant items, corrosive and reactive liquids are neutralized and deactivated, then grouted with cement. Organic liquids are solidified with 
calcium silicates. Noncompliant powders and particulates are immobilized with cement to meet WAC limits. Sludges are sent to the repackaging unit for criticality and wattage control. All treated materials are then packaged and certified for shipment to WIPP.

Soils: No mixed TRUW soil waste streams are listed in the IMWIR (DOE 1993). Some soils will likely be present in other waste streams, especially the debris waste streams. For WIPPWAC-compliant treatment, the only concern with soils is the potential presence of particulates, which, if above WAC limits, would be grouted before packaging for disposal. Figure 3-2 represents a generic treatment process for TRUW-contaminated soils from environmental restoration activities.

Debris Wastes: After noncompliant items are removed, all debris wastes are shredded and grouted, then placed in nongassing packaging and certified for shipment to WIPP. This grouting and repackaging should significantly reduce the gas generation rate from degradation of organic materials and corrodible metals (DOE 1994). The noncompliant items are treated the same as described above for solid process residues.

\subsubsection{Treatment to Meet RCRA LDRs}

The flow diagram in Figure 3-3 is designed to provide compliance with RCRA LDRs, compliance with the WIPP-WAC, and reduced gas generation rates. This method would substantially condense the waste and remove many of the hazardous constituents of the mixed TRUW. All treatment trains include a pretreatment step to separate liquids from solids or to sort out solids that have different physical properties. Although other oxidation means can be used to destroy organic matrix materials at individual sites, incineration is shown in the conceptual process flow diagram and analyzed in this study. All wastes are placed in final containers that are not expected to generate significant gas when disposed at WIPP.

Specific waste streams are handled as follows:

Aqueous Liquids: TRUW inventory contains a limited quantity of aqueous waste. The treatment train for this waste stream identifies only neutralization for aqueous liquids and aqueousbased organic destruction (oxidation) for treatment of aqueous streams with RCRA organics. These processes are followed by stabilization of the neutralized solutions. Reactives from sorting of other waste streams are assigned to deactivation.

Organic Liquids: After being separated from incoming wastes, organic liquids are sent to the incinerator for destruction.

Solid Process Residues: After the incoming residues are sorted and separated, the organic sludges and sludges containing regulated organics are sent to the incinerator for thermal destruction. 
Sludges that do not contain RCRA organics are sent for grouting. Debris is shredded and grouted. Corrosive or reactive liquids are neutralized and deactivated before being stabilized.

Soils: Soils are not indicated by the IMWIR (DOE 1993) to be contained in the incoming TRUW; a significant inventory is projected within the WIPP BIR-II (DOE 1995b) for Hanford, however. Soils will likely be present in other waste streams, particularly the debris waste stream. For treatment to meet RCRA LDRs, the soils with RCRA organics must be treated to destroy or remove the organics; this is accomplished in the incinerator. Soils with only RCRA inorganics must be stabilized to contain these constituents. This stabilization will also satisfy the WIPP-WAC criterion for particulates. Wastes are then packaged and certified for shipment to WIPP.

Debris Wastes: Inorganic debris wastes are shredded and grouted, then packaged and certified for shipment to WIPP. Organic debris are sent to the incinerator for thermal destruction. Corrosive and reactive liquids are neutralized and deactivated before being stabilized.

\subsection{TREATMENT TECHNOLOGIES}

The treatment trains represented by Figures 3-1 through 3-3 include some or all of the following treatment stages: front-end handling, pretreatment, primary treatment, secondary treatment, and preparation of final forms for disposal. The technologies involved in each of these stages of TRUW management are discussed in the following sections. Each technology described is a baseline technology currently in use, except wet oxidation. Wet oxidation is listed in Appendix $\mathrm{H}$ of the WM PEIS as an emerging technology, but because it is expected to become a demonstrated technology during the timeframe of the PEIS, it is postulated as the means of oxidizing organic matter in aqueous solutions.

\subsubsection{Front-End Handling}

Containers arriving at a treatment facility are removed from the transport vehicle and placed in a staging/storage area. The containers are visually examined, labeled, logged, and sent to inspection and assay. On the basis of existing records and inspection and assay results, the waste containers are grouped according to their treatment needs and assigned waste stream categories of 1000 to 8000 . Waste containers are opened by means of a remote arm, and their contents are dumped and sorted within shielded cells before being transferred for further processing. 


\subsubsection{Pretreatment}

Pretreatment, such as separation of solids from predominantly liquid wastes and separation of liquids from predominantly solid wastes, is necessary to maximize the efficiency of the specialized primary treatment modules.

\subsubsection{Liquid/Solids Separation}

Solid particulates can be separated from a fluid by filtration or by inducing sedimentation. Removal of large particulates from aqueous liquids (1000) and organic liquids (2000) is required before beginning primary treatment operations. Separated solids are sent to the solids treatment unit for additional pretreatment processing. The resulting liquids are sent for primary treatment, such as neutralization, cementation, or incineration.

\subsubsection{Solids Separation}

Different separation devices can be used to sort component solid wastes for appropriate treatment processes. For example, a grit screen filters out solids requiring further size reduction before primary treatment (Thompson 1992), and a density table gravity separator separates heavy combustibles and metals from the remaining inert fraction.

\subsubsection{Primary Treatment}

Primary treatment modules use technologies specifically applicable to the individual waste stream categories being processed. For example, all organic liquids are either incinerated or solidified, and aqueous liquids are neutralized, deactivated, wet oxidized, or grouted, depending upon their chemical composition and the flow diagram being considered. The following paragraphs describe the primary treatments modeled in the TRUW analysis within the WM PEIS.

\subsubsection{Neutralization}

Neutralization is the addition of chemicals to control hydrogen-ion concentration $(\mathrm{pH})$ in waste before it undergoes various physical, chemical, and biological treatment processes. For acid wastes, commonly used neutralizing chemicals include caustic soda, lime, calcium/sodium carbonate, or limestone, and for alkaline wastes, sulfuric, hydrochloric, or nitric acids (Corbitt 1990). 
Because it can be controlled to minimize emissions and volume increases, the neutralization process is assumed, for the purposes of this study, to cause little change in volume, mass, or radioactivity in the TRUW being treated, and to result in few contaminant emissions. This assumption is valid only for slow, controlled addition of concentrated acid/base, which may be difficult in field operations.

\subsubsection{Deactivation}

Deactivation is the removal or destruction of a reactive constituent from a waste stream using a combination of chemical and physical means. For TRUW management, only a small fraction of waste streams require deactivation. The deactivation process can be used to treat solid and liquid TRUW contaminated with reactives. The reactives are first separated from solid waste for destruction and removal. The uranium in liquid waste is then oxidized with hydrogen peroxide and sodium hypochlorite, precipitated with ferric sulfate and lime, and removed from the liquid stream by filtration.

Like neutralization, deactivation is assumed to cause little change in unit operation parameters and results in few contaminant emissions.

\subsubsection{Wet Oxidation}

Wet oxidation is the destruction of organic matter in aqueous solutions using intermediate temperatures and high pressures. Wet oxidation differs from conventional oxidation (or heating) because the reaction occurs entirely in the liquid phase, with the heat of combustion being released to the pressurized liquid in the reaction zone. The process typically operates at a temperature of $280^{\circ} \mathrm{C}$ and at pressures of up to $12.41 \mathrm{MPa}(1,800 \mathrm{psi})$. The resultant wastewater is discharged as a high-total-dissolved-solids aqueous waste. This waste is then sent to a grouting unit for solidification. Gas generated during the wet oxidation process is transferred to an off-gas treatment unit to remove RCRA-regulated compounds and meet Clean Air Act requirements before release to the atmosphere. Table 3-1.

Representative unit operation parameter values for wet oxidation are summarized in

\subsubsection{Incineration}

The thermal destruction of combustible organics by incineration is a rapidly emerging technology by which organics can be completely oxidized using high-temperature combustion. 
TABLE 3-1 Unit Operation Parameters for Wet Oxidation

\begin{tabular}{|c|c|c|}
\hline Parameter Description & Parameter Value & Assumptions \\
\hline \multicolumn{3}{|c|}{ Treated Product } \\
\hline Output mass/input mass & $9.0 \times 10^{-1}$ & \\
\hline Output volume/input volume & $9.0 \times 10^{-1}$ & \\
\hline $\begin{array}{l}\text { Output contamination/input } \\
\text { contamination } \\
\mathrm{Cs}, \mathrm{Sr} \\
\mathrm{Hg} \\
\text { All others } \\
\end{array}$ & $\begin{array}{l}1.0 \times 10^{-3} \\
1.0 \times 10^{-1} \\
9.9 \times 10^{-1} \\
\end{array}$ & $\begin{array}{l}\text { All contaminants remain in the } \\
\text { output stream except water-soluble } \\
\text { metal salts, such as } \mathrm{Sr} \text { and } \mathrm{Cs} \text {, which } \\
\text { will be separated. }\end{array}$ \\
\hline \multicolumn{3}{|c|}{ Salt Residual } \\
\hline Output mass/input mass & $1.0 \times 10^{-1}$ & \\
\hline Output volume/input volume & 1.0 & \\
\hline \multicolumn{3}{|l|}{$\begin{array}{l}\text { Output contamination/input } \\
\text { contamination }\end{array}$} \\
\hline $\mathrm{Cs}, \mathrm{Sr}$ & $9.9 \times 10^{-1}$ & \\
\hline $\mathrm{Hg}$ & $9.0 \times 10^{-1}$ & \\
\hline All others & $1.0 \times 10^{-3}$ & \\
\hline \multicolumn{3}{|c|}{ Atmospheric Release Fraction } \\
\hline $\begin{array}{l}\text { Radioactive and heavy } \\
\text { metals }{ }^{\mathrm{b}} \\
\text { (output mass/input mass) }\end{array}$ & $1.0 \times 10^{-11}$ & \\
\hline $\begin{array}{l}\text { Hazardous chemicals } \\
\text { (output mass/input mass) }\end{array}$ & $1.0 \times 10^{-6}$ & \\
\hline
\end{tabular}

a Parameter values are based on (1) estimated makeup of the incoming waste streams for a specific process operation, (2) previous calculations for a conceptual integrated mixed waste treatment facility (Thompson 1992), and (3) best engineering judgment about the expected behavior of the TRUW in a specific process operation.

b More recent literature (Dehmel and Hong 1994) indicate a partition factor of $1 \times 10^{-6}$ for all radionuclides except for $\mathrm{H}-3, \mathrm{C}-14$, and radioiodines. The partition factor is $6 \times 10^{-4}$ for $\mathrm{H}-3$ and $1.5 \times 10^{-5}$ for radioiodines. It was assumed that all C-14 activity is released without any retention or filtration. The value of $1 \times 10^{-11}$ applied in the WM PEIS analysis can be considered to be low. 
Various incinerator types and configurations have been developed to accept specific combustible waste types. Three of the most commonly used are the controlled air, rotary kiln, and fluidized-bed incinerators (Freeman 1988). Controlled air incinerators are typically used for low-density packaged waste streams but have been adapted to other applications, such as medical waste treatment, cremation, and liquid waste combustion. Rotary kiln incinerators can accept a wide variety of waste forms and sizes. Fluidized-bed incinerators have been adapted to accept liquid and slurry waste, sludges, and solids that have been reduced in size. Process descriptions for these three types of incinerators are summarized briefly below.

Controlled Air Incinerator. A controlled air incinerator is usually designed as a two-stage combustion process. Solid waste is fed into the primary chamber and burned at roughly 50 to 80 percent of the air requirement (a starved-air condition). The resultant smoke and products of incomplete combustion, primarily volatile hydrocarbons and carbon monoxide, pass to the secondary chamber where they undergo complete combustion (Gillins et al. 1993). The process is followed by an off-gas treatment for emissions control (Section 3.3.4.1).

Rotary Kiln Incinerator. A rotary kiln incinerator is capable of processing liquids and solids simultaneously. Heat radiates into the processing zone from the kiln wall to volatilize hazardous constituents into a gas stream. A postcombustion chamber equipped with independent burners and fans ensures subsequent complete destruction of the hazardous organic constituents. The incinerated solids are discharged to a high-temperature conveying device that transfers the materials to a coolermoisturizer unit. A rotary cooler provides the reverse-heat-transfer mechanism so the incinerated materials can be discharged at temperatures lower than $65^{\circ} \mathrm{C}$ for further handling. The process is followed by an off-gas treatment for emissions control (Section 3.3.4.1).

Fluidized-Bed Incinerator. A fluidized-bed incinerator consists of an air fluidizing system, a fluidized-bed vessel, a waste feed system, and off-gas cleanup equipment. Liquid and sludge wastes are introduced through a waste feed tank, and solid wastes are transferred from a solid waste feed hopper into the fluidized-bed vessel for combustion. Air from the fluidizing-air fan is preheated through a burner and distributed across the bottom of the bed by an air-distribution system. As the velocity of air increases, the granular bed material becomes suspended in a churning gas-solid mixture with physical properties similar to a fluid. A secondary reaction chamber may be required to ensure complete combustion for some hazardous organic components. Subsequent off-gas particulate removal is required (Section 3.3.4.1).

Representative unit operation parameters for incineration, including off-gas treatment, are summarized in Table 3-2. 
TABLE 3-2 Unit Operation Parameters for Incineration

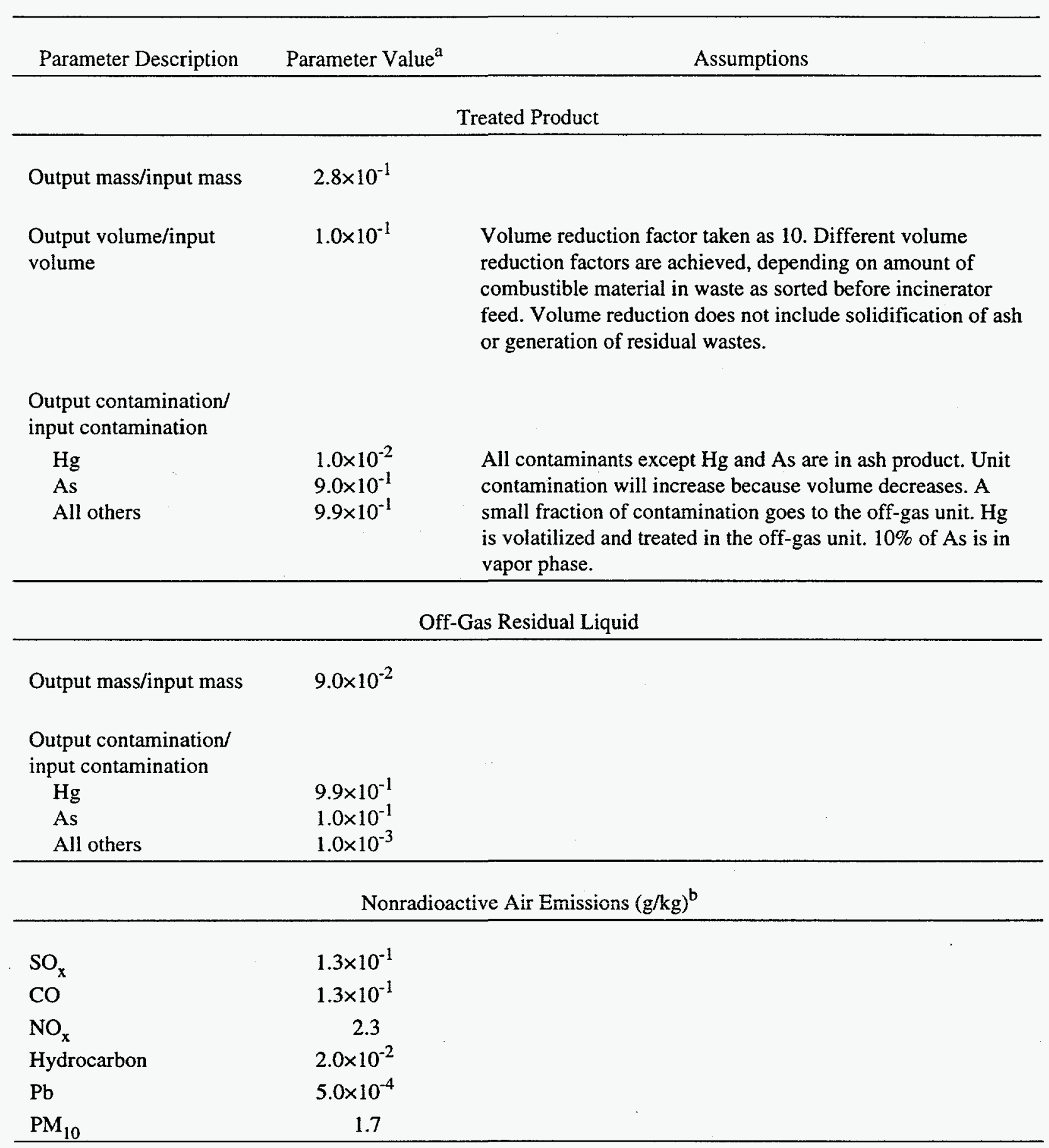


TABLE 3-2 (Cont.)

\begin{tabular}{ccc}
\hline Parameter Description & Parameter Value $^{\mathrm{a}}$ & Assumptions \\
\hline & Atmospheric Release Fraction \\
\hline
\end{tabular}

Radionuclides and heavy metals

$\mathrm{Zn}, \mathrm{Zn}-65$

$1.0 \times 10^{-4}$

$1.0 \times 10^{-12}$

As

$1.6 \times 10^{-6}$

Cd, Cd-113m,

$1.2 \times 10^{-7}$

Cd-115m

$2.8 \times 10^{-5}$

Derived from trial burn data.

Derived from trial burn data.

Derived from trial burn data.

$\mathrm{Hg}$

Derived from trial burn data.

All other

Based on estimated $\mathrm{Ci} / \mathrm{y}$ in process feed and $\mathrm{Ci} / \mathrm{yr}$ emitted for both LLW and LLMW incineration at the SRS. ${ }^{c}$

radionuclides

Hazardous constituents $\quad 1.0 \times 10^{-7}$

a Parameter values are based on (1) estimated makeup of the incoming waste streams for a specific process operation, (2) previous calculations for a conceptual integrated mixed waste treatment facility (Thompson 1992), and (3) best engineering judgment about the expected behavior of the TRUW in a specific process operation.

b Units are grams of pollutant emissions per kilogram of input waste.

c The release rate of particulate radionuclides such as U-238 and Pu-239 during TRUW incineration may be on the order of $0.1 \%$ (Dehmel and Hong 1994). Assuming a decontamination factor of 1,000 for particulate removal, the overall release fraction is $1 \times 10^{-6}$. The value of $2.8 \times 10^{-5}$ is assumed to be conservative.

Source: Lazaro (1994).

\subsubsection{Shredding}

Shredding breaks waste material into smaller sizes, making it more nearly uniform. A shredding unit is usually equipped with a shredder, a solids separation unit, and a dust collection/ filtration unit. Shredded wastes are transferred to an appropriate treatment process to remove volatile contaminants.

\subsubsection{Secondary Treatment}

Secondary treatments, such as treating the gas that comes from an incinerator, stabilizing and solidifying residual solids, and packaging the waste going to disposal, must be done to process the products of the primary treatment. 


\subsubsection{Off-Gas Treatment}

Incineration of TRUW to meet RCRA LDRs releases a variety of pollutants. An effective, reliable off-gas treatment facility needs to be employed to condition the off-gas and to collect the pollutants. Off-gas treatment systems are normally classified as wet, dry, or semi-dry. Wet systems use water to quench, or saturate, the off-gas and generate a wet secondary waste. In a dry system, no water is used and a dry secondary waste is generated. Semi-dry systems use water in limited quantities to generate a dry secondary waste.

A complete off-gas system includes an off-gas quenching facility, an air pollution control device, an optional off-gas reheating facility, induced draft fans, and a stack. Off-gas quenching is usually applied before treatment to provide gas cooling. After off-gas quenching, the pollutantspecific treatment technologies listed below will be applied as appropriate (Dalton et al. 1992).

Acidic-Gas Removal. Acidic-gas is converted to a salt by reacting with sodium- or calciumbased alkali reagents. Resultant salts can be collected as a dry particulate or dissolved in a liquid solution.

Particulate Removal. Mechanisms include inertial impaction, Brownian diffusion, interception, gravity settling, and electrostatic attraction.

Heavy Metal Removal. A wet process involves condensation of the volatile toxic metal species to mists and small liquid droplets. Dry and semidry processes involve injection of alkali solids to serve as seed particles for agglomeration and collection of metals.

Removal of Products of Incomplete Combustion. Large, condensable hydrocarbons can be collected in the same manner as heavy metals. Activated carbon adsorption and catalytic destruction can be applied for dioxins, furans, and polyaromatic hydrocarbons.

$N O_{x}$ Abatement. In dry nitrogen-oxides $\left(\mathrm{NO}_{\mathrm{x}}\right)$ abatement, a reducing agent is mixed with the flue gas and induced to react with the $\mathrm{NO}_{\mathrm{x}}$ to form nitrogen, water, and carbon dioxide in the flue gas. In wet $\mathrm{NO}_{x}$ abatement, the NO component is converted to nitrogen dioxide, which can then be scrubbed with a caustic solution and converted to a nitrate salt.

If a wet off-gas treatment system is used, an off-gas reheating facility is needed to eliminate a steam plume at the stack and to protect dry filtration components. The resulting residues of the offgas treatment process (the pollutant in concentrated form, a secondary waste of the pollution control system, and unreacted additives) require additional processing before they can be disposed (Section 3.3.4.2). 


\subsubsection{Stabilization/Solidification}

Solidification and stabilization (1) improve waste-handling and physical characteristics, (2) decrease the surface area across which pollutants can transfer or leach, and (3) limit the solubility of or detoxify hazardous constituents (Freeman 1988). In the process of solidification, materials are added to the waste to produce a monolithic block of treated waste with high structural integrity. A chemical bonding between the hazardous constituent and the additive may or may not be involved. In the process of stabilization, waste is converted to a more chemically stable form.

Currently available solidification and stabilization methods can be categorized by their binding agents. Grout solidification uses an agent such as cement or a polymer, and solidification of organics uses agents such as calcium silicates. Table 3-3 gives representative unit operation parameters for solidification.

\subsubsection{Packaging/Repackaging}

The TRUW containers that exceed the WIPP-WAC criticality limit for plutonium-239 fissile-gram equivalent or the wattage limit for the TRUPACT-II are sorted and repackaged. Certifiable TRUW and treated noncertifiable TRUW are typically packaged or repackaged in 55 -gallon containers. To reduce potential gas generation, nongassing containers made of a non-steel metal (e.g., nickel alloy) are used in the packaging facility (for intermediate and more extensive treatment).

\subsubsection{Final Forms}

Solidified and stabilized wastes will be packaged in drums for transfer to a back-end facility, ready for processing through radioassay and final certification (Feizollahi and Shropshire 1992). Treated off-gas can be discharged directly into the atmosphere.

\subsection{INTERIM STORAGE}

Current regulations allow the shipping area in the packaging facility to be used to store nonmixed TRUW indefinitely and mixed TRUW for up to 90 days awaiting shipment to WIPP (40 CFR 262). If a longer period of interim storage is needed, appropriate storage facilities would be designed and constructed. Although treated waste will have been stabilized, which will lower particulate emissions, appropriate locations will be monitored with constant-air radiation monitors and hand-held contamination survey instruments. 
TABLE 3-3 Unit Operation Parameters for Solidification

\begin{tabular}{|c|c|c|}
\hline Parameter Description & Parameter Value $^{\mathrm{a}}$ & Assumptions \\
\hline \multicolumn{3}{|c|}{ Treated Product } \\
\hline Output mass/input mass & 2.7 & \\
\hline \multicolumn{3}{|l|}{ Output volume/input volume } \\
\hline Cement-based solidification & 1.2 & $\begin{array}{l}\text { Volume increase of about } 20 \% . \\
\text { Actual volume increase factor } \\
\text { depends on waste/cement ratio } \\
\text { and site-specific treatability } \\
\text { testing. }\end{array}$ \\
\hline $\begin{array}{l}\text { Polymer or organic } \\
\text { solidification }\end{array}$ & 1.6 & Volume increase of about $60 \%$ \\
\hline $\begin{array}{l}\text { Output contamination/input } \\
\text { contamination }\end{array}$ & $9.9 \times 10^{-1}$ & $\begin{array}{l}\text { No change in contamination. } \\
\text { Unit contamination will decrease } \\
\text { because of volume increase. }\end{array}$ \\
\hline \multicolumn{3}{|c|}{ Atmospheric Release Fraction } \\
\hline Radionuclides and heavy metals & $2 \times 10^{-10}$ & \\
\hline Hazardous constituents & $1 \times 10^{-5}$ & \\
\hline
\end{tabular}

a Parameter values are based on (1) estimated makeup of the incoming waste streams for a specific process operation, (2) previous calculations or a conceptual integrated mixed waste treatment facility (Thompson 1992), and (3) best engineering judgment about the expected behavior of the TRUW in a specific process operation. 


\section{EXISTING AND PLANNED FACILITIES}

Existing DOE treatment, storage, and disposal facilities for TRUW are limited in both numbers and capacities. The data presented in this section are based primarily on EG\&G (1994). The data are limited to "planned/approved" and to existing facilities. Planned/approved means that conceptual design of the facility has been completed and that detailed Title II design has been initiated.

Table 4-1 partially lists the capabilities and capacities of existing and planned/approved TRUW facilities at DOE sites. (A more complete listing is provided in Appendix E of Volume III of the Storage and Disposition of Weapons - Usable Fissile Materials Draft Programmatic Environmental Impact Statement [DOE 1996c].) This information is the baseline for determining of the number, sizes, and costs of facilities needed to treat and package TRUW for disposal. 
TABLE 4-1 Capacities and Capabilities of Existing and Planned/Approved TRUW Facilities

\begin{tabular}{|c|c|c|c|c|c|}
\hline Site & Facility & Type & Status & $\begin{array}{l}\text { Capacity } \\
\left(\mathrm{m}^{3} / \mathrm{yr}\right)\end{array}$ & $\begin{array}{l}\text { Capabilities } \\
\text { Comments }\end{array}$ \\
\hline ANL-E & TRUEX & Packaging & Existing & NA & Remote packaging using glovebox \\
\hline Hanford & $\begin{array}{l}\text { Transuranic Storage and } \\
\text { Assay Facility }\end{array}$ & Pretreatment & Existing & NA & NA \\
\hline Hanford & $\begin{array}{l}\text { Waste Receiving and } \\
\text { Processing Facility, } \\
\text { Module } 1\end{array}$ & Pretreatment & $\begin{array}{l}\text { Planned } \\
\text { approved }\end{array}$ & 1,400 & $\begin{array}{l}\text { Characterization, sorting, and } \\
\text { repackaging }\end{array}$ \\
\hline INEL & $\begin{array}{l}\text { Stored Waste Examination } \\
\text { Pilot Plant }\end{array}$ & Pretreatment & Existing & 1.000 & $\begin{array}{l}\text { Nondestructive assay/examination } \\
\text { and drum venting }\end{array}$ \\
\hline INEL & $\begin{array}{l}\text { Waste Characterization } \\
\text { Facility }\end{array}$ & Pretreatment & In progress & 200 & $\begin{array}{l}\text { Characterization and limited } \\
\text { repackaging; currently in detailed } \\
\text { design stage }\end{array}$ \\
\hline INEL & Waste Storage Facility & Storage & In progress & 20,000 & $\begin{array}{l}\text { Pre-engineered metal buildings for } \\
\text { RCRA-compliant storage; under } \\
\text { construction }\end{array}$ \\
\hline INEL & $\begin{array}{l}\text { Transuranic Storage Area - } \\
\text { Retrieval Enclosure }\end{array}$ & Retrieval & In progress & 2,100 & $\begin{array}{l}\text { Manual and remote retrieval of } \\
\text { waste stored in earthen berms; } \\
\text { under construction }\end{array}$ \\
\hline LANL & $\begin{array}{l}\text { Waste Characterization, } \\
\text { Reduction, and Repackaging } \\
\text { Facility }\end{array}$ & Pretreatment & Existing & NA & Waste volume reduction \\
\hline LANL & Pretreatment Plant & Pretreatment & Existing & 200 & $\begin{array}{l}\text { Filtration, neutrali-zation, } \\
\text { precipitation, sorption (fixation) }\end{array}$ \\
\hline LANL & $\begin{array}{l}\text { Nondestructive Evaluation/ } \\
\text { Nondestructive Assay } \\
\text { Facility }\end{array}$ & Pretreatment & Existing & NA & NA \\
\hline LANL & $\begin{array}{l}\text { Transuranic Storage Area } \\
\text { Retrieval Enclosure }\end{array}$ & Retrieval & $\begin{array}{l}\text { Planned/ } \\
\text { approved }\end{array}$ & 1,500 & Planned for 1995 \\
\hline LANL & Controlled Air Incinerator & Incineration & Existing & 680 & $\begin{array}{l}\text { Currently shut down and being } \\
\text { dismantled }\end{array}$ \\
\hline LANL & $\begin{array}{l}\text { Plutonium Facility } \\
\text { Solidification }\end{array}$ & Solidification & Existing & 7.7 & Portland cement stabilization \\
\hline ORR & $\begin{array}{l}\text { Waste Examination and } \\
\text { Assay Facility }\end{array}$ & Pretreatment & Existing & NA & Nondestructive examination/assay \\
\hline ORR & $\begin{array}{l}\text { Melton Valley } \\
\text { Immobilization Facility }\end{array}$ & Stabilization & Existing & 189 & Cement stabilization \\
\hline
\end{tabular}


TABLE 4-1 (Cont.)

\begin{tabular}{|c|c|c|c|c|c|}
\hline Site & Facility & Type & Status & $\begin{array}{c}\text { Capacity } \\
\left(\mathrm{m}^{3} / \mathrm{yr}\right)\end{array}$ & $\begin{array}{l}\text { Capabilities/ } \\
\text { Comments }\end{array}$ \\
\hline RFETS & $\begin{array}{l}\text { Supercompaction and } \\
\text { Repackaging Facility }\end{array}$ & Pretreatment & Existing & 949 & Compaction \\
\hline RFETS & $\begin{array}{l}\text { Advanced Size Reduction } \\
\text { Facility }\end{array}$ & Pretreatment & Existing & 1,819 & Size reduction \\
\hline RFETS & Size Reduction Vault & Pretreatment & Existing & 1,864 & Size reduction \\
\hline RFETS & $\begin{array}{l}\text { Process Waste Treatment } \\
\text { Facility }\end{array}$ & $\begin{array}{l}\text { Aqueous waste } \\
\text { treat-ment }\end{array}$ & Existing & 149,000 & $\begin{array}{l}\text { Deactivation, decontamina-tion, } \\
\text { evaporation, immobilization, and } \\
\text { solidification }\end{array}$ \\
\hline RFETS & $\begin{array}{l}\text { Organic and Sludge } \\
\text { Immobilization System }\end{array}$ & Stabilization & Existing & 497 & Concentration \\
\hline SRS & $\begin{array}{l}\text { Low Activity TRUW } \\
\text { Facility Retrieval }\end{array}$ & Pretreatment & $\begin{array}{l}\text { Planned/ } \\
\text { approved }\end{array}$ & NA & $\begin{array}{l}\text { Scheduled to begin operations in } \\
1996\end{array}$ \\
\hline SRS & $\begin{array}{l}\text { Transuranic Waste Storage } \\
\text { Pads }\end{array}$ & Storage & Existing & NA & $\begin{array}{l}19 \text { storage pads in E-Area as of } \\
6 / 95 \text {. }\end{array}$ \\
\hline
\end{tabular}

Notes: $\mathrm{NA}=$ not available; RCRA = Resource Conservation and Recovery Act; TSCA = Toxic Substances Control Act.

Source: EG\&G 1994. 


\section{TRUW ALTERNATIVES CONSIDERED}

This section describes the TRUW alternatives analyzed in the WM PEIS. The waste loads to be treated and the volumes to be shipped to WIPP for disposal are listed for each alternative. The estimated environmental releases for one alternative at one site are provided as an example of the environmental release data tabulated for all sites for all alternatives (the comprehensive data are provided in Appendix B of this report).

The TRUW alternatives and the related assumptions identified in Sections 5.1 and 5.2 provide an analytical basis for the data presented in Section 5.3 and for the impacts analysis presented in Chapters 2, 8, and 10 of the PEIS. The alternatives listed in Section 5.2.3 result from combining six separate $\mathrm{CH}$ - and RH-TRUW management cases (described in Sections 5.2.1 and 5.2.2), which were developed separately because the differences in radiological characteristics of $\mathrm{CH}$ - and RH-TRUW require separate facilities. The separate $\mathrm{CH}$ - and RH-TRUW cases were combined into six alternatives (No Action, Decentralized, Regionalized 1, Regionalized 2, Regionalized 3, and Centralized) because the impacts of the separate activities at sites with both types of TRUW occur during the same time period and are additive.

The grouping of DOE sites and facilities under the Decentralized, Regionalized, and Centralized alternatives described in Chapter 2 is complicated by the need to accommodate the three possible treatment requirements, described in Section 3.2, and by the number of sites required to manage TRUW; on the other hand, the expectation that there will only be one disposal site (WIPP) is a simplifying factor. The rationale for selecting these TRUW alternatives for the impacts analysis is presented in Section 2.5.

The alternatives dictate the waste treatment configurations that define how much waste is treated, where, and to what degree. The waste data reported in this report and in the references are used in the WM PEIS analyses as follows. Waste data are used to calculate treatment, storage, and disposal module costs, worker populations, and resource requirements; waste loads and characteristics are used in accident analyses. The quantities and characteristics of waste shipped between sites are used to calculate heath risks to transportation workers and the general public along transportation routes, as described in the transportation appendix to the WM PEIS (Appendix E). Radiological doses and health risks to workers and the public are calculated using air emissions during normal operations (see Appendix B of this report) and throughput values for the treatment modules (as described in Section 4.2 of the WM PEIS, "Human Health Risk Methods"). The environmental release data are also considered in the environmental impacts analysis. 


\subsection{ASSUMPTIONS}

\subsubsection{General}

The Waste Isolation Pilot Plant Land Withdrawl Act of 1992 provides for the disposal of $176,600 \mathrm{~m}^{3}$ (6.2 million $\mathrm{ft}^{3}$ ) of "defense" TRUW at WIPP. The WVDP and certain DOE nuclear weapons sites have small amounts of "nondefense" TRUW. For the purposes of this study, all TRUW is assumed to result from defense activities and is to be shipped to WIPP for disposal after treatment and certification.

Design and construction of new facilities will begin in 1997, and new facilities will become operational in the year 2007. All current inventory, retrievably stored waste, and waste generated from 1996 to 2017 will be treated between approximately 2007 and 2017. Waste generated after 2017 will be treated as soon after its generation as is feasible.

WIPP will accept TRUW for disposal from 1998 until 2018. The acceptance rate for waste will average $250,000 \mathrm{ft}^{3} / \mathrm{yr}$ for 20 years. Because future WIPP-WAC may change over time, the WM PEIS analyses will use current WIPP criteria, an intermediate treatment to reduce gas generation, and treatment to LDRs so that the full range of the impacts of processing, treating, and shipping TRUW to WIPP for disposal will be adequately covered in the analysis. The actual level of treatment will be determined in the Record of Decision for the WIPP SEIS-II (DOE 1996b).

Waste for shipment will be characterized at the shipping site and must meet State requirements of both the shipping site and the receiving site. Portable characterization facilities may be required for generators of smaller volumes of TRUW.

The analysis assumes that characterizing and repackaging waste will be possible, if necessary, to meet Department of Transportation or RCRA requirements for transport, as well as State shipping and receiving requirements.

\subsubsection{Treatment and Processing}

Processing TRUW to meet WIPP-WAC and treating to an intermediate level by shredding, grouting, and using containers made of a material that will reduce gas generation potential will be assumed practical at any site possessing TRUW.

Treatment of CH- and RH-TRUW to LDRs will be performed only at WIPP or at one or more of the following six sites that currently have large inventories of TRUW: Hanford, INEL/Argonne National Laboratory-West (ANL-W), LANL, ORR (ORR would treat only 
RH-TRUW because it has little CH-TRUW, and no alpha LLMW), RFETS, and SRS. It is assumed that treatment to LDRs at the smaller sites is impractical because of costs and economics of scale associated with larger facilities.

Sites with above- and below-ground retrievably stored TRUW (Hanford, INEL, LANL, ORR, and SRS) have sufficient packaging capability for the above-ground stored TRUW, but require additional repackaging facilities for below-ground retrievably stored TRUW.

Nickel alloy drums would likely be used if containers are changed from stainless steel drums to reduce gas generation.

\subsubsection{Waste Volumes and Waste Streams}

Waste stream categories 6000 to 8000 are not included in waste load calculations because they are assumed to be set aside to await extensive characterization prior to treatment and special processing. These streams constitute less than $1 \%$ of the total inventory.

Mixed waste data are based on data in the IMWIR (DOE 1993) and MWIR (DOE 1995a). Mixed TRUW will be categorized by radioactive characteristics (that is, whether it is contact handled or remote handled), by waste stream categories, as described in Section 2.1, and by RCRA hazardous constituents.

Estimates of the volume of TRUW resulting from environmental restoration activities at DOE sites can be assessed separately and the impacts may be added to those for waste management alternatives to produce a combined analysis.

\subsection{DESCRIPTIONS OF ALTERNATIVES}

The CH- and RH-TRUW cases for analysis were developed by applying the three treatment options to varied configurations for consolidating waste for treatment.

TRUW from individual sites may be sent to regional centers for treatment (Regionalized alternative cases); it may be treated on the site where it was generated (Decentralized alternative cases); or it may be sent from all sites to WIPP for treatment (Centralized alternative). All treated TRUW is then shipped to WIPP for disposal. Feasible options for the treatment technologies (Section 3), treatment level, and siting configuration of TRUW processing are combined into eight treatment cases for evaluation in the WM PEIS. The eight treatment cases taken with the two No Action cases were used to analyze TRUW management in the WM PEIS. 
The specifics of each alternative are described by $\mathrm{CH}$ - and $\mathrm{RH}-\mathrm{TRUW}$ treatment cases in Section 5.2. The TRUW alternatives analyzed in the PEIS are combinations of the CH- and RHTRUW cases, as shown in Section 5.2.3. The annual TRUW volumes projected to be contributed for treatment by each originating site can be found in Tables 5-1 and 5-2. The No Action alternative annual waste volumes are provided separately (in Table 5-1) because they would consist only of projected TRUW. The annual waste loads contributed for the other alternatives, listed in Table 5-2, by treatment case, were developed by adding the current TRUW inventories to 20 years of projected TRUW generation, and dividing by 10 (this assumes that treatment will begin 10 years from now and continue for 10 additional years).

For sites with TRUW, current policy and procedures are based on the report, Data Collection on Existing and Planned/Approved Waste Management Facilities in Support of the WM PEIS (EG\&G 1994). The following sites have TRUW: ANL-E, ETEC, Hanford, INEL/ANL-W, LANL, LBL, LLNL, Mound, NTS, ORR, PGDP, RFETS, SNL, SRS, UMC, and WVDP.

TABLE 5-1 Projected Annual Newly Generated Waste Volumes by Originating Site for the No Action Alternative

\begin{tabular}{|c|c|c|c|}
\hline \multicolumn{2}{|c|}{ CH-TRUW } & \multicolumn{2}{|c|}{ RH-TRUW } \\
\hline $\begin{array}{c}\text { Originating } \\
\text { Site }\end{array}$ & $\begin{array}{l}\text { Volume } \\
\left(\mathrm{m}^{3} / \mathrm{yr}\right)\end{array}$ & $\begin{array}{c}\text { Originating } \\
\text { Site }\end{array}$ & $\begin{array}{l}\text { Volume } \\
\left(\mathrm{m}^{3} / \mathrm{yr}\right)\end{array}$ \\
\hline ANL-E & 47 & ANL-E & 17 \\
\hline ETEC & $-^{a}$ & Hanford & 976 \\
\hline Hanford & 464 & INEL & 23 \\
\hline INEL & 14 & LANL & 0.5 \\
\hline LANL & 126 & ORR & 19 \\
\hline LBL & 0.01 & SRS & 1 \\
\hline LLNL & 74 & & \\
\hline Mound & 60 & & \\
\hline NTS & - & & \\
\hline ORR & 18 & & \\
\hline PGDP & - & & \\
\hline RFETS & 238 & & \\
\hline SNL & - & & \\
\hline SRS & 576 & & \\
\hline UMC & 2 & & \\
\hline WVDP & - & & \\
\hline
\end{tabular}


TABLE 5-2 Projected Annual Waste Volumes by Originating Site for All Except No Action Alternative

\begin{tabular}{ccccc}
\hline \multicolumn{2}{c}{ CH-TRUW } & & \multicolumn{2}{c}{ RH-TRUW } \\
\cline { 1 - 2 } \cline { 5 - 5 } $\begin{array}{c}\text { Originating } \\
\text { Site }\end{array}$ & $\begin{array}{c}\text { Volume } \\
\left(\mathrm{m}^{3} / \mathrm{yr}\right)\end{array}$ & & $\begin{array}{c}\text { Originating } \\
\text { Site }\end{array}$ & $\begin{array}{c}\text { Volume } \\
\left(\mathrm{m}^{3} / \mathrm{yr}\right)\end{array}$ \\
\hline ANL-E & $9.5 \times 10^{1}$ & & ANL-E & $3.4 \times 10^{1}$ \\
ETEC & $2.0 \times 10^{-3}$ & & Hanford & $1.6 \times 10^{3}$ \\
Hanford & $4.6 \times 10^{3}$ & & INEL & $5.7 \times 10^{1}$ \\
INEL & $3.8 \times 10^{3}$ & & LANL & 8.9 \\
LANL & $1.1 \times 10^{3}$ & & ORR & $1.7 \times 10^{2}$ \\
LBL & $1.0 \times 10^{-1}$ & & SRS & 2.1 \\
LLNL & $1.7 \times 10^{2}$ & & & \\
Mound & $1.5 \times 10^{2}$ & & & \\
NTS & $6.1 \times 10^{1}$ & & & \\
ORR & $1.0 \times 10^{2}$ & & & \\
PGDP & 1.35 & & \\
RFETS & $6.2 \times 10^{2}$ & & \\
SNL & $9.5 \times 10^{-2}$ & & \\
SRS & $1.7 \times 10^{3}$ & & & \\
UMC & 4.0 & & \\
WVDP & $4.5 \times 10^{-2}$ & &
\end{tabular}

\subsubsection{CH-TRUW Cases}

The case number in parentheses is included for easy reference to TRUW data reported by case number in other appendices and technical reports.

\subsubsection{No Action (Case 1)}

With this case, DOE would continue to characterize and prepare newly generated and retrievably stored TRUW where existing and approved facilities are available, and continue to store TRUW in existing facilities.

\subsubsection{Decentralized Treatment to WIPP-WAC at 10 Sites (Case 4)}

This case considers processing and packaging CH-TRUW to meet WIPP-WAC at all 16 sites and shipping from generators of smaller volumes to 10 sites for interim storage as follows. 


$\begin{array}{cccc}\text { Origin } & \text { Storage Destination } & \text { Origin } & \text { Storage Destination } \\ \text { ANL-E } & \text { ANL-E } & \text { ETEC } & \text { NTS } \\ \text { Hanford } & \text { Hanford } & \text { NTS } & \text { NTS } \\ \text { LBL } & \text { Hanford } & \text { ORR } & \text { ORR } \\ \text { INEL/ANL-W } & \text { INEL/ANL-W } & \text { PGDP } & \text { ORR } \\ \text { LANL } & \text { LANL } & \text { UMC } & \text { ORR } \\ \text { SNL } & \text { LANL } & \text { RFETS } & \text { RFETS } \\ \text { LLNL } & \text { LLNL } & \text { SRS } & \text { SRS } \\ \text { Mound } & \text { Mound } & & \\ \text { WVDP } & \text { Mound } & & \end{array}$

In this configuration, CH-TRUW would be shipped from the 10 sites to WIPP for disposal.

\subsubsection{Regionalized Intermediate Treatment at Five Sites (Case 5)}

Contact-handled TRUW from 16 sites would be treated to an intermediate level at five sites in the configuration below.

$\begin{array}{cc}\text { Origin } & \text { Treatment Destination } \\ \text { Hanford } & \text { Hanford } \\ \text { LBL } & \text { Hanford } \\ \text { LLNL } & \text { Hanford } \\ \text { INEL/ANL-W } & \text { INEL/ANL-W } \\ \text { NTS } & \text { INEL/ANL-W } \\ \text { LANL } & \text { LANL } \\ \text { SNL } & \text { LANL } \\ \text { RFETS } & \text { RFETS }\end{array}$

$\begin{array}{cc}\text { Origin } & \text { Treatment Destination } \\ \text { ANL-E } & \text { SRS } \\ \text { ETEC } & \text { INEL/ANL-W } \\ \text { Mound } & \text { SRS } \\ \text { ORR } & \text { SRS } \\ \text { PGDP } & \text { SRS } \\ \text { SRS } & \text { SRS } \\ \text { UMC } & \text { SRS } \\ \text { WVDP } & \text { SRS }\end{array}$

In this configuration, CH-TRUW would be shipped for treatment from 11 to 5 sites. The five sites would then ship treated TRUW to WIPP for disposal.

\subsubsection{Regionalized Treatment to LDRs at Five Sites (Case 6)}

Contact-handled TRUW from 16 sites would be treated to meet LDRs at 5 sites in the same configuration as case 5. The TRUW would be shipped from the five sites to WIPP for disposal.

\subsubsection{Regionalized Treatment to LDRs at Three Sites (Case 8)}

Contact-handled TRUW from 16 sites would be treated to meet LDRs at 3 sites in the following configuration: 


$\begin{array}{cccc}\text { Origin } & \text { Treatment Destination } & \text { Origin } & \text { Treatment Destination } \\ \text { Hanford } & \text { Hanford } & \text { ANL-E } & \text { SRS } \\ \text { LBL } & \text { Hanford } & \text { Mound } & \text { SRS } \\ \text { LLNL } & \text { Hanford } & \text { ORR } & \text { SRS } \\ \text { ETEC } & \text { INEL/ANL-W } & \text { PGDP } & \text { SRS } \\ \text { INEL/ANL-W } & \text { INEL/ANL-W } & \text { SRS } & \text { SRS } \\ \text { LANL } & \text { INEL/ANL-W } & \text { UMC } & \text { SRS } \\ \text { NTS } & \text { INEL/ANL-W } & \text { WVDP } & \text { SRS } \\ \text { RFETS } & \text { INEL/ANL-W } & & \\ \text { SNL } & \text { INEL/ANL-W } & & \end{array}$

This configuration involves shipment from 13 sites for treatment. The waste would then be shipped from three sites to WIPP for disposal.

\subsubsection{Centralized Treatment to LDRs at One Site (Case 9)}

All sites would ship CH-TRUW to WIPP for treatment. Waste would be treated to LDRs at WIPP and disposed at WIPP.

\subsubsection{RH-TRUW Cases}

The case number in parentheses is included for easy reference to TRUW data reported by case number in other appendices and technical reports.

\subsubsection{No Action (Case 10)}

With this case, DOE would use existing facilities to package RH-TRUW in accordance with current policies and would store the waste indefinitely (no disposal at WIPP). Existing situations, relationships between sites, and procedures are based on the report, Data Collection on Existing and Planned/Approved Waste Management Facilities in Support of the WM PEIS (EG\&G 1994). The six sites with RH-TRUW or that will generate RH-TRUW are ANL-E, Hanford, INEL/ANL-W, LANL, ORR, and SRS.

\subsubsection{Decentralized Treatment to WIPP-WAC at Six Sites (Case 11)}

This case is the same as the No Action alternative with one exception. Additional required facilities would be constructed at the sites to allow them to process and package RH-TRUW to meet 
WIPP-WAC before shipping it to WIPP for disposal. This alternative approximates current policy for RH-TRUW.

\subsubsection{Regionalized Intermediate Treatment at Two Sites (Case 14)}

Remote-handled TRUW from six sites would be treated to an intermediate level at two sites, in the configuration that follows:

$\begin{array}{cc}\text { Origin } & \text { Treatment Destination } \\ \text { Hanford } & \text { Hanford } \\ \text { INEL/ANL-W } & \text { Hanford } \\ \text { LANL } & \text { Hanford } \\ \text { ANL-E } & \text { ORR } \\ \text { ORR } & \text { ORR } \\ \text { SRS } & \text { ORR }\end{array}$

Treated waste would be shipped to WIPP for disposal.

\subsubsection{Regionalized Treatment to LDRs at Two Sites (Case 15)}

This case would be the same as the previous one, except that the RH-TRUW would be treated to meet LDRs before it would be shipped to WIPP for disposal.

\subsubsection{Combined CH- and RH-TRUW Alternatives}

The CH- and RH-TRUW cases were combined to form alternatives as follows:

- No Action alternative: CH Case 1 and RH Case 10,

- Decentralized alternative: $\mathrm{CH}$ Case 4 and RH Case 11,

- Regionalized 1 alternative: CH Case 5 and RH Case 14,

- Regionalized 2 alternative: CH Case 6 and RH Case 15 ,

- Regionalized 3 alternative: CH Case 8 and RH Case 15, and

- Centralized alternative: CH Case 9 and RH Case 15. 


\subsection{PROJECTED WASTE VOLUMES FOR THE ALTERNATIVES}

The constituents of their feed streams must be known if the products of treatment trains are to be calculated. To use the treatment trains depicted in Figures 3-1 through 3-3, we estimated average values based on analysis of IMWIR (DOE 1993) and MWIR (DOE 1995a) data, and, in some cases, engineering judgment. Packing fractions, defined as the ratio of the actual inventory volume to the reported volume (which generally included the volume of the container holding the waste) were determined from IMWIR (DOE 1993) and MWIR (DOE 1995a) data and applied to the projected inventory.

\subsubsection{Input to Treatment}

Data on the waste volumes from individual sites that would require treatment are provided in Table 5-3 for all TRUW alternatives, for $\mathrm{CH}$ and $\mathrm{RH}$ waste.

\subsubsection{Treatment Products for Disposal}

Treatment products to be disposed of at WIPP are identified for contact- and remotehandled waste in Table 5-4 for all TRUW alternatives except the No Action alternative, for which disposal does not occur. These volumes are an input to the transportation, human health risk, and cost analyses. 
TABLE 5-3 Treatment Site Waste Volumes ( $\left.\mathrm{m}^{3} / \mathrm{yr}\right)$ for Representative Treatment Technologies

\begin{tabular}{|c|c|c|c|c|c|c|c|c|c|c|}
\hline \multirow[b]{2}{*}{$\begin{array}{c}\text { Treatment } \\
\text { Site/ } \\
\text { Technology }\end{array}$} & \multicolumn{6}{|c|}{ CH-TRUW } & \multicolumn{4}{|c|}{ RH-TRUW } \\
\hline & $\begin{array}{c}\text { No } \\
\text { Action }\end{array}$ & $\begin{array}{c}\text { Decentralized } \\
\text { Treatment to } \\
\text { WIPP-WAC } \\
\text { 10 Sites }\end{array}$ & $\begin{array}{c}\text { Regionalized } \\
\text { Intermediate } \\
\text { Treatment } \\
5 \text { Sites }\end{array}$ & $\begin{array}{l}\text { Regionalized } \\
\text { Treatment } \\
\text { to LDRs } \\
5 \text { Sites } \\
\end{array}$ & $\begin{array}{c}\text { Regionalized } \\
\text { Treatment } \\
\text { to LDRs } \\
3 \text { Sites } \\
\end{array}$ & $\begin{array}{c}\text { Centralized } \\
\text { Treatment } \\
\text { to LDRs } \\
1 \text { Site } \\
\end{array}$ & $\begin{array}{c}\text { No } \\
\text { Action }\end{array}$ & $\begin{array}{c}\text { Decentralized } \\
\text { Treatment to } \\
\text { WIPP-WAC } \\
6 \text { Sites } \\
\end{array}$ & $\begin{array}{c}\text { Regionalized } \\
\text { Intermediate } \\
\text { Treatment } \\
2 \text { Sites } \\
\end{array}$ & $\begin{array}{c}\text { Regionalized } \\
\text { Treatment } \\
\text { to LDRs } \\
2 \text { Sites } \\
\end{array}$ \\
\hline \multicolumn{11}{|l|}{ ANL-E } \\
\hline Grouting & NA & $8.9 \times 10^{1}$ & NA & NA & NA & NA & NA & 3.4 & NA & NA \\
\hline Shredding & NA & NA & NA & NA & NA & NA & NA & $\mathrm{NA}$ & NA & NA \\
\hline Packaging & $4.7 \times 10^{1}$ & $1.1 \times 10^{2}$ & $9.6 \times 10^{1}$ & $9.6 \times 10^{1}$ & $9.6 \times 10^{1}$ & $9.6 \times 10^{1}$ & $1.7 \times 10^{1}$ & $3.5 \times 10^{1}$ & $3.4 \times 10^{1}$ & $3.4 \times 10^{1}$ \\
\hline \multicolumn{11}{|l|}{ Hanford } \\
\hline Grouting & NA & $7.8 \times 10^{2}$ & $5.1 \times 10^{2}$ & $4.1 \times 10^{2}$ & $4.1 \times 10^{2}$ & NA & NA & $5.8 \times 10^{1}$ & $3.1 \times 10^{2}$ & $3.2 \times 10^{2}$ \\
\hline Shredding & $\mathrm{NA}$ & NA & $6.5 \times 10^{2}$ & $5.9 \times 10^{2}$ & $5.9 \times 10^{2}$ & NA & NA & $\mathrm{NA}$ & $5.4 \times 10^{2}$ & $5.5 \times 10^{2}$ \\
\hline Packaging & $9.8 \times 10^{2}$ & $1.8 \times 10^{3}$ & $7.1 \times 10^{2}$ & $5.6 \times 10^{2}$ & $5.6 \times 10^{2}$ & $3.0 \times 10^{3}$ & $7.6 \times 10^{2}$ & $1.0 \times 10^{3}$ & $4.4 \times 10^{2}$ & $4.2 \times 10^{2}$ \\
\hline \multicolumn{11}{|l|}{ INEL } \\
\hline Grouting & NA & $4.1 \times 10^{2}$ & $2.0 \times 10^{3}$ & $2.2 \times 10^{3}$ & $2.9 \times 10^{3}$ & NA & NA & 7.56 & NA & NA \\
\hline Shredding & $\mathrm{NA}$ & NA & $2.9 \times 10^{3}$ & $3.1 \times 10^{3}$ & $4.2 \times 10^{3}$ & NA & NA & NA & $\mathrm{NA}$ & NA \\
\hline Packaging & $1.4 \times 10^{1}$ & $4.0 \times 10^{3}$ & $3.2 \times 10^{2}$ & $2.7 \times 10^{3}$ & $3.7 \times 10^{3}$ & $3.8 \times 10^{3}$ & $2.3 \times 10^{1}$ & $6.1 \times 10^{1}$ & $5.7 \times 10^{1}$ & $5.7 \times 10^{1}$ \\
\hline \multicolumn{11}{|l|}{ LANL } \\
\hline Incineration & NA & NA & NA & $2.6 \times 10^{2}$ & NA & NA & NA & NA & NA & NA \\
\hline Grouting & NA & $1.2 \times 10^{2}$ & $4.9 \times 10^{2}$ & $5.5 \times 10^{2}$ & NA & NA & NA & $8.9 \times 10^{-1}$ & NA & $\mathrm{NA}$ \\
\hline Shredding & NA & NA & $6.6 \times 10^{2}$ & $6.9 \times 10^{2}$ & NA & NA & NA & NA & NA & NA \\
\hline Packaging & $1.3 \times 10^{2}$ & $1.1 \times 10^{3}$ & $9.2 \times 10^{2}$ & $6.9 \times 10^{2}$ & $1.1 \times 10^{3}$ & $1.1 \times 10^{3}$ & $5.0 \times 10^{-}$ & 9.24 & 8.9 & $8.9 \times 10^{1}$ \\
\hline \multicolumn{11}{|l|}{ LBL } \\
\hline Incineration & NA & $\mathrm{NA}$ & NA & NA & NA & NA & NA & $\mathrm{NA}$ & NA & NA \\
\hline Grouting & $\mathrm{NA}$ & $1.0 \times 10^{-2}$ & $\mathrm{NA}$ & NA & NA & NA & NA & $\mathrm{NA}$ & NA & NA \\
\hline Shredding & NA & NA & NA & NA & NA & NA & NA & NA & NA & NA \\
\hline Packaging & $1.0 \times 10^{-2}$ & $1.0 \times 10^{-1}$ & $1.0 \times 10^{-1}$ & $1.0 \times 10^{-1}$ & $1.0 \times 10^{-1}$ & $1.0 \times 10^{-1}$ & NA & $\mathrm{NA}$ & NA & NA \\
\hline \multicolumn{11}{|l|}{ LLNL } \\
\hline Packaging & $7.4 \times 10^{1}$ & $2.0 \times 10^{2}$ & $1.7 \times 10^{2}$ & $1.7 \times 10^{2}$ & $1.7 \times 10^{2}$ & $1.7 \times 10^{2}$ & NA & NA & NA & NA \\
\hline
\end{tabular}


TABLE 5-3 (Cont.)

\begin{tabular}{|c|c|c|c|c|c|c|c|c|c|c|}
\hline \multirow[b]{2}{*}{$\begin{array}{l}\text { Treatment } \\
\text { Site/ } \\
\text { Technology } \\
\end{array}$} & \multicolumn{6}{|c|}{ CH-TRUW } & \multicolumn{4}{|c|}{ RH-TRUW } \\
\hline & $\begin{array}{c}\text { No } \\
\text { Action }\end{array}$ & $\begin{array}{c}\text { Decentralized } \\
\text { Treatment to } \\
\text { WIPP-WAC } \\
10 \text { Sites } \\
\end{array}$ & $\begin{array}{c}\text { Regionalized } \\
\text { Intermediate } \\
\text { Treatment } \\
5 \text { Sites } \\
\end{array}$ & $\begin{array}{c}\text { Regionalized } \\
\text { Treatment } \\
\text { to LDRs } \\
5 \text { Sites } \\
\end{array}$ & $\begin{array}{c}\text { Regionalized } \\
\text { Treatment } \\
\text { to LDRs } \\
3 \text { Sites } \\
\end{array}$ & $\begin{array}{c}\text { Centralized } \\
\text { Treatment } \\
\text { to LDRs } \\
1 \text { Site } \\
\end{array}$ & $\begin{array}{c}\text { No } \\
\text { Action } \\
\end{array}$ & $\begin{array}{c}\text { Decentralized } \\
\text { Treatment to } \\
\text { WIPP-WAC } \\
5 \text { Sites } \\
\end{array}$ & $\begin{array}{c}\text { Regionalized } \\
\text { Intermediate } \\
\text { Treatment } \\
2 \text { Sites } \\
\end{array}$ & $\begin{array}{c}\text { Regionalized } \\
\text { Treatment } \\
\text { to LDRs } \\
2 \text { Sites } \\
\end{array}$ \\
\hline \multicolumn{11}{|l|}{ Mound } \\
\hline Grouting & NA & 2.47 & NA & NA & NA & NA & NA & NA & NA & NA \\
\hline Shredding & NA & NA & NA & NA & NA & $\mathrm{NA}$ & NA & NA & NA & $\mathrm{NA}$ \\
\hline Packaging & NA & $1.8 \times 10^{1}$ & $1.7 \times 10^{1}$ & $1.7 \times 10^{1}$ & $1.7 \times 10^{1}$ & $1.7 \times 10^{1}$ & NA & NA & NA & $\mathrm{NA}$ \\
\hline \multicolumn{11}{|l|}{ NTS } \\
\hline Incineration & NA & NA & NA & NA & NA & NA & NA & NA & $\mathrm{NA}$ & $\mathrm{NA}$ \\
\hline Grouting & NA & 6.12 & NA & NA & NA & NA & NA & NA & NA & NA \\
\hline Shredding & NA & NA & NA & NA & NA & NA & NA & NA & NA & $\mathrm{NA}$ \\
\hline Packaging & NA & $6.4 \times 10^{1}$ & $6.1 \times 10^{1}$ & $6.1 \times 10^{1}$ & $6.1 \times 10^{1}$ & $6.1 \times 10^{1}$ & NA & NA & NA & NA \\
\hline Incineration & $\mathrm{NA}$ & NA & NA & NA & NA & NA & NA & NA & NA & $1.6 \times 10^{2}$ \\
\hline Grouting & $\mathrm{NA}$ & NA & NA & $\mathrm{NA}$ & NA & NA & NA & $2.1 \times 10^{1}$ & $3.1 \times 10^{1}$ & $2.9 \times 10^{l}$ \\
\hline Shredding & $\mathrm{NA}$ & NA & NA & NA & $\mathrm{NA}$ & NA & NA & NA & $3.1 \times 10^{1}$ & NA \\
\hline Packaging & NA & NA & NA & NA & NA & NA & $1.4 \times 10^{1}$ & $1.5 \times 10^{2}$ & $1.7 \times 10^{2}$ & $4.8 \times 10^{1}$ \\
\hline \multicolumn{11}{|l|}{ PGDP } \\
\hline Incineration & NA & NA & NA & $\mathrm{NA}$ & NA & $\mathrm{NA}$ & NA & NA & $\mathrm{NA}$ & NA \\
\hline Grouting & $\mathrm{NA}$ & $8.4 \times 10^{1}$ & NA & $\mathrm{NA}$ & NA & $\mathrm{NA}$ & NA & $\mathrm{NA}$ & NA & $\mathrm{NA}$ \\
\hline Shredding & $\mathrm{NA}$ & NA & NA & NA & NA & NA & NA & $\mathrm{NA}$ & NA & NA \\
\hline Packaging & NA & 1.6 & 1.4 & 1.4 & 1.4 & 1.4 & NA & NA & NA & NA \\
\hline \multicolumn{11}{|l|}{ RFETS } \\
\hline Incineration & NA & NA & NA & $1.2 \times 10^{2}$ & NA & $\mathrm{NA}$ & NA & $\mathrm{NA}$ & $\mathrm{NA}$ & NA \\
\hline Grouting & $\mathrm{NA}$ & $7.1 \times 10^{1}$ & $2.6 \times 10^{2}$ & $2.9 \times 10^{2}$ & NA & NA & NA & NA & $\mathrm{NA}$ & NA \\
\hline Shredding & NA & NA & $4.1 \times 10^{2}$ & $4.3 \times 10^{2}$ & NA & NA & NA & NA & NA & NA \\
\hline Packaging & $2.4 \underset{2}{x} 10$ & $6.3 \times 10^{2}$ & $4.7 \times 10^{2}$ & $3.6 \times 10^{2}$ & $6.0 \times 10^{2}$ & $6.0 \times 10^{2}$ & NA & NA & $\mathrm{NA}$ & NA \\
\hline \multicolumn{11}{|l|}{ SNL } \\
\hline Grouting & NA & $9.5 \times 10^{-3}$ & NA & NA & NA & NA & $\mathrm{NA}$ & NA & $\mathrm{NA}$ & NA \\
\hline Shredding & NA & NA & NA & NA & NA & NA & NA & NA & $\mathrm{NA}$ & NA \\
\hline Packaging & $\mathrm{NA}$ & $9.9 \times 10^{-2}$ & $9.5 \times 10^{-2}$ & $9.5 \times 10^{-2}$ & $9.5 \times 10^{-2}$ & $9.5 \times 10^{-2}$ & NA & $\mathrm{NA}$ & NA & NA \\
\hline
\end{tabular}




\section{TABLE 5-3 (Cont.)}

\begin{tabular}{|c|c|c|c|c|c|c|c|c|c|c|}
\hline \multirow[b]{2}{*}{$\begin{array}{l}\text { Treatment } \\
\text { Site/ } \\
\text { Technology } \\
\end{array}$} & \multicolumn{6}{|c|}{ CH-TRUW } & \multicolumn{4}{|c|}{ RH-TRUW } \\
\hline & $\begin{array}{c}\text { No } \\
\text { Action }\end{array}$ & $\begin{array}{c}\text { Decentralized } \\
\text { Treatment to } \\
\text { WIPP-WAC } \\
10 \text { Sites }\end{array}$ & $\begin{array}{c}\text { Regionalized } \\
\text { Intermediate } \\
\text { Treatment } \\
5 \text { Sites } \\
\end{array}$ & $\begin{array}{c}\text { Regionalized } \\
\text { Treatment } \\
\text { to LDRs } \\
5 \text { Sites } \\
\end{array}$ & $\begin{array}{c}\text { Regionalized } \\
\text { Treatment } \\
\text { to LDRs } \\
3 \text { Sites } \\
\end{array}$ & $\begin{array}{c}\text { Centralized } \\
\text { Treatment } \\
\text { to LDRs } \\
\text { I Site }\end{array}$ & $\begin{array}{c}\text { No } \\
\text { Action }\end{array}$ & $\begin{array}{c}\text { Decentralized } \\
\text { Treatment to } \\
\text { WIPP-WAC } \\
5 \text { Sites }\end{array}$ & $\begin{array}{c}\text { Regionalized } \\
\text { Intermediate } \\
\text { Treatment } \\
2 \text { Sites }\end{array}$ & $\begin{array}{l}\text { Regionalized } \\
\text { Treatment } \\
\text { to LDRs } \\
2 \text { Sites }\end{array}$ \\
\hline \multicolumn{11}{|l|}{ SRS } \\
\hline Incineration & NA & $\mathrm{NA}$ & $\mathrm{NA}$ & $1.6 \times 10^{1}$ & $1.6 \times 10^{1}$ & NA & NA & NA & NA & NA \\
\hline Grouting & NA & $3.6 \times 10^{1}$ & $2.6 \times 10^{2}$ & $2.5 \times 10^{2}$ & $2.5 \times 10^{2}$ & NA & NA & $7.1 \times 10^{-2}$ & NA & $\mathrm{NA}$ \\
\hline Shredding & NA & NA & $3.7 \times 10^{2}$ & $3.8 \times 10^{2}$ & $3.8 \times 10^{2}$ & NA & NA & NA & NA & $\mathrm{NA}$ \\
\hline Packaging & $5.8 \times 10^{2}$ & $9.3 \times 10^{2}$ & $3.6 \times 10^{2}$ & $3.3 \times 10^{2}$ & $3.3 \times 10^{2}$ & $1.7 \times 10^{3}$ & 1.0 & 1.3 & 2.1 & 2.1 \\
\hline \multicolumn{11}{|l|}{ UMC } \\
\hline Incineration & NA & $\mathrm{NA}$ & NA & NA & NA & NA & NA & NA & NA & $\mathrm{NA}$ \\
\hline Grouting & NA & $4.0 \times 10^{-1}$ & NA & $\mathrm{NA}$ & NA & NA & NA & $\mathrm{NA}$ & NA & $\mathrm{NA}$ \\
\hline Shredding & NA & NA & NA & $\mathrm{NA}$ & $\mathrm{NA}$ & NA & NA & NA & NA & NA \\
\hline Packaging & 2.00 & 4.16 & 4.0 & 4.0 & 4.0 & 4.0 & NA & NA & NA & $\mathrm{NA}$ \\
\hline \multicolumn{11}{|l|}{ WIPP } \\
\hline Incineration & NA & NA & NA & NA & $\mathrm{NA}$ & $1.9 \times 10^{3}$ & NA & NA & NA & NA \\
\hline Grouting & $\mathrm{NA}$ & NA & NA & NA & $\mathrm{NA}$ & $1.6 \times 10^{3}$ & NA & NA & NA & NA \\
\hline Shredding & $\mathrm{NA}$ & NA & NA & NA & NA & $1.8 \times 10^{3}$ & NA & NA & NA & NA \\
\hline Packaging & NA & NA & NA & NA & $\mathrm{NA}$ & $2.3 \times 10^{3}$ & NA & $\mathrm{NA}$ & $\mathrm{NA}$ & $\mathrm{NA}$ \\
\hline
\end{tabular}

a $\mathrm{NA}=$ Not applicable. 
TABLE 5-4 WIPP Disposal Waste Volumes $\left(\mathrm{m}^{3} / \mathrm{yr}\right)$ by Treatment Site for All Except No Action Alternative ${ }^{\mathrm{a}, \mathrm{b}}$

\begin{tabular}{|c|c|c|c|c|c|c|c|c|}
\hline \multirow[b]{2}{*}{$\begin{array}{c}\text { Treatment } \\
\text { Site }\end{array}$} & \multicolumn{5}{|c|}{ CH-TRUW } & \multicolumn{3}{|c|}{ RH-TRUW } \\
\hline & $\begin{array}{c}\text { Decentralized } \\
\text { Treatment to } \\
\text { WIPP-WAC } \\
10 \text { Sites } \\
\end{array}$ & $\begin{array}{c}\text { Regionalized } \\
\text { Intermediate } \\
\text { Treatment } \\
5 \text { Sites } \\
\end{array}$ & $\begin{array}{c}\text { Regionalized } \\
\text { Treatment to } \\
\text { LDRs } \\
5 \text { Sites } \\
\end{array}$ & $\begin{array}{c}\text { Regionalized } \\
\text { Treatment to } \\
\text { LDRs } \\
3 \text { Sites } \\
\end{array}$ & $\begin{array}{c}\text { Centralized } \\
\text { Treatment to } \\
\text { LDRs } \\
\text { I Site } \\
\end{array}$ & $\begin{array}{c}\text { Decentralized } \\
\text { Treatment to } \\
\text { WIPP-WAC } \\
6 \text { Sites } \\
\end{array}$ & $\begin{array}{c}\text { Regionalized } \\
\text { Intermediate } \\
\text { Treatment } \\
2 \text { Sites } \\
\end{array}$ & $\begin{array}{c}\text { Regionalized } \\
\text { Treatment to } \\
\text { LDRs } \\
2 \text { Sites } \\
\end{array}$ \\
\hline ANL-E & $1.3 \times 10^{2}$ & $N^{c}$ & NA & NA & NA & $3.9 \times 10^{1}$ & $\mathrm{NA}$ & NA \\
\hline Hanford & $2.0 \times 10^{3}$ & $7.7 \times 10^{2}$ & $6.0 \times 10^{2}$ & $6.9 \times 10^{2}$ & NA & $1.1 \times 10^{3}$ & $4.7 \times 10^{3}$ & $4.5 \times 10^{2}$ \\
\hline INEL & $4.4 \times 10^{3}$ & $3.5 \times 10^{3}$ & $2.9 \times 10^{3}$ & $4.1 \times 10^{3}$ & NA & $6.7 \times 10^{1}$ & $\mathrm{NA}$ & NA \\
\hline LANL & $1.2 \times 10^{3}$ & $1.0 \times 10^{3}$ & $7.7 \times 10^{2}$ & NA & NA & $1.0 \times 10^{1}$ & NA & NA \\
\hline LBL & NA & NA & NA & NA & NA & NA & $\mathrm{NA}$ & NA \\
\hline LLNL & $2.2 \times 10^{2}$ & NA & NA & NA & $\mathrm{NA}$ & NA & NA & NA \\
\hline Mound & $1.9 \times 10^{1}$ & NA & NA & NA & NA & NA & NA & NA \\
\hline NTS & $6.9 \times 10^{1}$ & NA & NA & NA & NA & NA & NA & NA \\
\hline ORR & 6.28 & NA & NA & NA & $\mathrm{NA}$ & $1.7 \times 10^{2}$ & $1.8 \times 10^{2}$ & $5.3 \times 10^{1}$ \\
\hline PGDP & NA & NA & NA & NA & NA & $\mathrm{NA}$ & NA & NA \\
\hline RFETS & $6.9 \times 10^{2}$ & $5.1 \times 10^{2}$ & $3.9 \times 10^{2}$ & NA & NA & $\mathrm{NA}$ & $\mathrm{NA}$ & $\mathrm{NA}$ \\
\hline SNL & NA & NA & NA & NA & NA & NA & NA & $\mathrm{NA}$ \\
\hline SRS & $1.0 \times 10^{3}$ & $3.4 \times 10^{2}$ & $3.2 \times 10^{2}$ & $5.5 \times 10^{2}$ & NA & 1.5 & NA & NA \\
\hline UMC & NA & $\mathrm{NA}$ & $\mathrm{NA}$ & $\mathrm{NA}$ & NA & NA & NA & NA \\
\hline WIPP & NA & NA & NA & NA & $2.5 \times 10^{3}$ & NA & NA & NA \\
\hline
\end{tabular}

a In the No Action alternatives, TRUW is not disposed at WIPP, but is stored indefinitely at DOE generation/storage sites.

b It is assumed that treatment facilities will operate for 10 years. Therefore, the total treated waste to be disposed at WIPP is 10 times the values given in the table.

c NA $=$ Not applicable. 
TABLE 5-5 Projected Environmental Release Profiles for INEL Under the CH Regionalized Case 8 Treatment to LDRs at Three Sites-Incineration

\begin{tabular}{|c|c|c|c|c|c|}
\hline \multicolumn{3}{|c|}{ Radiological Profile } & \multicolumn{3}{|c|}{ Chemical Profile } \\
\hline Radionuclide & $\begin{array}{c}\text { Total } \\
(\mathrm{Ci} / \mathrm{yr}) \\
\end{array}$ & $\begin{array}{c}\text { Released } \\
(\mathrm{Ci} / \mathrm{yr})\end{array}$ & Contaminant & $\begin{array}{c}\text { Total } \\
(\mathrm{kg} / \mathrm{yr})\end{array}$ & $\begin{array}{r}\text { Released } \\
(\mathrm{kg} / \mathrm{yr}) \\
\end{array}$ \\
\hline \multicolumn{6}{|c|}{ Incineration-Volume: $8.9 \times 10^{2} \mathrm{~m}^{3} / \mathrm{yr}$} \\
\hline Sr-90 & $1.4 \times 10^{1}$ & $4.0 \times 10^{-4}$ & Carbon tetrachloride & $6.2 \times 10^{3}$ & $6.1 \times 10^{-4}$ \\
\hline $\mathrm{Y}-90$ & 7.11 & $2.0 \times 10^{-4}$ & Methyl alcohol & $1.6 \times 10^{1}$ & $1.6 \times 10^{-6}$ \\
\hline Ru-106 & $9.0 \times 10^{-3}$ & $2.6 \times 10^{-7}$ & Butanol & $1.0 \times 10^{1}$ & $1.0 \times 10^{-6}$ \\
\hline Cs-137 & $1.6 \times 10^{1}$ & $4.6 \times 10^{-4}$ & Methyl chloroform & $1.9 \times 10^{4}$ & $1.8 \times 10^{-3}$ \\
\hline $\mathrm{BA}-137 \mathrm{~m}$ & 4.7 & $1.3 \times 10^{-4}$ & Methylene chloride & $8.5 \times 10^{1}$ & $8.4 \times 10^{-6}$ \\
\hline $\mathrm{Ce}-144$ & $6.5 \times 10^{-2}$ & $1.9 \times 10^{-6}$ & $\begin{array}{l}\text { 1,1,2-trichloro-1,2,2- } \\
\text { trifluoroethane }\end{array}$ & $6.3 \times 10^{3}$ & $6.2 \times 10^{-4}$ \\
\hline Pm-147 & $3.4 \times 10^{1}$ & $9.8 \times 10^{-4}$ & Ethyl benzene & $1.4 \times 10^{1}$ & $1.4 \times 10^{-6}$ \\
\hline Th-232 & $3.8 \times 10^{-3}$ & $1.1 \times 10^{-7}$ & Toluene & $1.4 \times 10^{1}$ & $1.4 \times 10^{-6}$ \\
\hline$U-233$ & $1.1 \times 10^{1}$ & $2.9 \times 10^{-4}$ & Xylene & $3.2 \times 10^{1}$ & $3.1 \times 10^{-6}$ \\
\hline U-235 & $3.1 \times 10^{-3}$ & $8.9 \times 10^{-8}$ & Cadmium & 7.6 & $1.2 \times 10^{-5}$ \\
\hline $\mathrm{U}-238$ & $8.2 \times 10^{-3}$ & $2.3 \times 10^{-7}$ & Lead & $6.8 \times 10^{1}$ & $1.9 \times 10^{-3}$ \\
\hline Np-237 & $7.5 \times 10^{-3}$ & $2.1 \times 10^{-7}$ & & & \\
\hline Pu-238 & $4.7 \times 10^{3}$ & $1.3 \times 10^{-1}$ & & & \\
\hline Pu-239 & $2.1 \times 10^{3}$ & $6.1 \times 10^{-2}$ & & & \\
\hline $\mathrm{Pu}-240$ & $6.5 \times 10^{2}$ & $1.8 \times 10^{-2}$ & & & \\
\hline $\mathrm{Pu}-241$ & $2.5 \times 10^{4}$ & $7.2 \times 10^{-1}$ & & & \\
\hline $\mathrm{Pu}-242$ & $7.5 \times 10^{-2}$ & $2.1 \times 10^{-6}$ & & & \\
\hline Am-241 & $5.6 \times 10^{3}$ & $1.6 \times 10^{-1}$ & & & \\
\hline $\mathrm{Cm}-244$ & $1.3 \times 10^{1}$ & $3.7 \times 10^{-4}$ & & & \\
\hline Cf -252 & $7.5 \times 10^{4}$ & $2.1 \times 10^{-8}$ & & & \\
\hline
\end{tabular}

\subsubsection{Environmental Releases}

The environmental releases used in the analysis are estimated for a given technology by multiplying release fractions (see Tables 3-1 through 3-3) by the corresponding treatment input volume. A technology-specific breakdown is presented in Tables 5-5, 5-6, and 5-7 for one site (INEL) for treatment of CH-TRUW to LDR at three sites (Case 8). Environmental releases are summed. Contaminant profiles and total environmental releases are presented for each alternative and treatment site in Appendix B of this document. 
TABLE 5-6 Projected Environmental Release Profiles for INEL Under the CH Regionalized Case 8 Treatment to LDRs at Three Sites-Wet Oxidation

\begin{tabular}{|c|c|c|c|c|c|}
\hline \multicolumn{3}{|c|}{ Radiological Profile } & \multicolumn{3}{|c|}{ Chemical Profile } \\
\hline Radionuclide & $\begin{array}{c}\text { Total } \\
(\mathrm{Ci} / \mathrm{yr}) \\
\end{array}$ & $\begin{array}{c}\text { Released } \\
(\mathrm{Ci} / \mathrm{yr}) \\
\end{array}$ & Contaminant & $\begin{array}{c}\text { Total } \\
(\mathrm{kg} / \mathrm{yr})\end{array}$ & $\begin{array}{c}\begin{array}{c}\text { Released } \\
(\mathrm{kg} / \mathrm{yr})\end{array} \\
\end{array}$ \\
\hline \multicolumn{6}{|c|}{ Wet Oxidation-Volume: $3.7 \times 10^{2} \mathrm{~m}^{3} / \mathrm{yr}$} \\
\hline Sr-90 & 4.0 & $4.0 \times 10^{-11}$ & Carbon tetrachloride & 8.2 & $8.2 \times 10^{-6}$ \\
\hline Y-90 & 1.5 & $1.5 \times 10^{-11}$ & Methyl alcohol & $3.6 \times 10^{-1}$ & $3.6 \times 10^{-7}$ \\
\hline Ru-106 & $3.2 \times 10^{-3}$ & $3.2 \times 10^{-14}$ & Butanol & $2.3 \times 10^{-1}$ & $2.3 \times 10^{-7}$ \\
\hline Cs- 137 & 4.7 & $4.7 \times 10^{-11}$ & Methyl chloroform & $1.4 \times 10^{1}$ & $1.4 \times 10^{-5}$ \\
\hline Ba- $137 m$ & $9.8 \times 10^{-1}$ & $9.8 \times 10^{-12}$ & Methylene chloride & $6.0 \times 10^{1}$ & $6.0 \times 10^{-5}$ \\
\hline Ce-144 & $2.3 \times 10^{-2}$ & $2.3 \times 10^{-13}$ & $\begin{array}{l}\text { 1,1,2-trichloro-1,2,2- } \\
\text { trifluoroethane }\end{array}$ & $2.5 \times 10^{1}$ & $2.5 \times 10^{-5}$ \\
\hline $\mathrm{Pm}-147$ & $1.2 \times 10^{1}$ & $1.2 \times 10^{-10}$ & Ethyl benzene & $3.3 \times 10^{-5}$ & $3.3 \times 10^{-11}$ \\
\hline Th-232 & $1.4 \times 10^{-3}$ & $1.4 \times 10^{-14}$ & Toluene & $3.3 \times 10^{-5}$ & $3.3 \times 10^{-11}$ \\
\hline E-233 & 3.8 & $3.8 \times 10^{-11}$ & Xylene & $6.8 \times 10^{-5}$ & $6.8 \times 10^{-11}$ \\
\hline $\mathrm{U}-235$ & $9.4 \times 10^{-4}$ & $9.4 \times 10^{-15}$ & Cadmium & $6.9 \times 10^{-1}$ & $6.9 \times 10^{-12}$ \\
\hline U-238 & $1.9 \times 10^{-3}$ & $1.9 \times 10^{-14}$ & Mercury & 2.8 & $2.8 \times 10^{-11}$ \\
\hline Np-237 & $2.7 \times 10^{-3}$ & $2.7 \times 10^{-14}$ & Lead & $4.2 \times 10^{3}$ & $4.2 \times 10^{-8}$ \\
\hline $\mathrm{Pu}-238$ & $1.1 \times 10^{3}$ & $1.1 \times 10^{-8}$ & & & \\
\hline Pu-239 & $5.5 \times 10^{2}$ & $5.5 \times 10^{-9}$ & & & \\
\hline Pu-240 & $1.6 \times 10^{2}$ & $1.6 \times 10^{-9}$ & & & \\
\hline $\mathrm{Pu}-241$ & $5.9 \times 10^{3}$ & $5.9 \times 10^{-8}$ & & & \\
\hline Pu-242 & $1.8 \times 10^{-2}$ & $1.8 \times 10^{-13}$ & & & \\
\hline Am-241 & $1.4 \times 10^{3}$ & $1.4 \times 10^{-8}$ & & & \\
\hline $\mathrm{Cm}-244$ & 4.7 & $4.7 \times 10^{-4}$ & & & \\
\hline Cf- 252 & $2.7 \times 10^{-4}$ & $2.7 \times 10^{-15}$ & & & \\
\hline
\end{tabular}


TABLE 5-7 Projected Environmental Release Profiles for INEL Under the CH Regionalized Case 8 Treatment to LDRs at Three Sites-Solidification

\begin{tabular}{|c|c|c|c|c|c|}
\hline \multicolumn{3}{|c|}{ Radiological Profile } & \multicolumn{3}{|c|}{ Chemical Profile } \\
\hline Radionuclide & $\begin{array}{l}\text { Total } \\
(\mathrm{Ci} / \mathrm{yr}) \\
\end{array}$ & $\begin{array}{c}\text { Released } \\
(\mathrm{Ci} / \mathrm{yr}) \\
\end{array}$ & Contaminant & $\begin{array}{c}\text { Total } \\
(\mathrm{kg} / \mathrm{yr})\end{array}$ & $\begin{array}{c}\text { Released } \\
(\mathrm{kg} / \mathrm{yr})\end{array}$ \\
\hline \multicolumn{6}{|c|}{ Solidification-Volume: $2.9 \times 10^{3} \mathrm{~m}^{3} / \mathrm{yr}$} \\
\hline Sr-90 & $7.9 \times 10^{1}$ & $1.6 \times 10^{-8}$ & Carbon tetrachloride & $1.7 \times 10^{2}$ & $1.7 \times 10^{-3}$ \\
\hline$Y-90$ & $2.9 \times 10^{1}$ & $5.8 \times 10^{-9}$ & Methyl alcohol & $3.6 \times 10^{-4}$ & $3.6 \times 10^{-9}$ \\
\hline Ru-106 & $6.5 \times 10^{-2}$ & $1.3 \times 10^{-11}$ & Butanol & $2.3 \times 10^{-4}$ & $2.3 \times 10^{-9}$ \\
\hline Cs -137 & $9.5 \times 10^{1}$ & $1.9 \times 10^{-8}$ & Methyl chloroform & $2.7 \times 10^{2}$ & $2.7 \times 10^{-3}$ \\
\hline BA- $137 \mathrm{~m}$ & $2.0 \times 10^{1}$ & $4.0 \times 10^{-9}$ & Methylene chloride & $1.3 \times 10^{3}$ & $1.3 \times 10^{-2}$ \\
\hline $\mathrm{Ce}-144$ & $4.9 \times 10^{-1}$ & $9.9 \times 10^{-11}$ & $\begin{array}{l}\text { 1,1,2-trichloro-1,2,2- } \\
\text { trifluoroethane }\end{array}$ & $5.5 \times 10^{2}$ & $5.5 \times 10^{-3}$ \\
\hline$P m-147$ & $2.4 \times 10^{2}$ & $4.9 \times 10^{-8}$ & Ethyl benzene & $2.9 \times 10^{-1}$ & $2.9 \times 10^{-6}$ \\
\hline Th-232 & $2.9 \times 10^{-2}$ & $5.8 \times 10^{-12}$ & Toluene & $2.9 \times 10^{-1}$ & $2.9 \times 10^{-6}$ \\
\hline U-233 & $7.9 \times 10^{1}$ & $1.6 \times 10^{-8}$ & Xylene & $6.4 \times 10^{-1}$ & $6.4 \times 10^{-6}$ \\
\hline$U-235$ & $1.9 \times 10^{-2}$ & $3.9 \times 10^{-12}$ & Cadmium & $1.0 \times 10^{1}$ & $2.1 \times 10^{-9}$ \\
\hline U-238 & $4.1 \times 10^{-2}$ & $8.1 \times 10^{-12}$ & Mercury & $6.2 \times 10^{1}$ & $1.2 \times 10^{-8}$ \\
\hline $\mathrm{Np}-237$ & $5.7 \times 10^{-2}$ & $1.1 \times 10^{-11}$ & Lead & $8.1 \times 10^{4}$ & $1.6 \times 10^{-5}$ \\
\hline $\mathrm{Pu}-238$ & $2.3 \times 10^{4}$ & $4.5 \times 10^{-6}$ & & & \\
\hline Pu-239 & $1.1 \times 10^{4}$ & $2.2 \times 10^{-6}$ & & & \\
\hline Pu-240 & $3.2 \times 10^{3}$ & $6.5 \times 10^{-7}$ & & & \\
\hline Pu-241 & $1.2 \times 10^{5}$ & $2.4 \times 10^{-5}$ & & & \\
\hline $\mathrm{Pu}-242$ & $3.6 \times 10^{-1}$ & $7.3 \times 10^{-11}$ & & & \\
\hline $\mathrm{Am}-241$ & $2.8 \times 10^{4}$ & $5.5 \times 10^{-6}$ & & & \\
\hline $\mathrm{Cm}-244$ & $9.9 \times 10^{1}$ & $1.9 \times 10^{-8}$ & & & \\
\hline Cf- 252 & $5.7 \times 10^{-3}$ & $1.1 \times 10^{-12}$ & & & \\
\hline
\end{tabular}




\section{APPLICATION OF TRUW SOURCE TERMS}

This report has presented information specific to TRUW within the DOE system. The data presented in this document are primary inputs to developing the costs, health risks, and socioeconomic and environmental impacts of treating, packaging, and shipping TRUW for disposal. The impacts are described in Chapter 8 of the WM PEIS, "Impacts of the Management of Transuranic Waste," and are the basis for the comparison of the TRUW alternatives in Section 2.6 of the WM PEIS. Information associated with TRUW transportation may be found in Appendix E of the WM PEIS. Additional technical information and detailed contaminant profiles and total environmental releases for each site and alternative are contained in Appendix B of this report. 


\section{REFERENCES}

Corbitt, R.A., 1990, Standard Handbook of Environmental Engineering, McGraw-Hill, Inc., New York.

Dalton, J.D., et al., 1992, An Assessment of Off-Gas Treatment Technologies for Application to Thermal Treatment of Department of Energy Wastes. DOE/MWIP-1, U.S. Department of Energy, Washington, D.C. Sept.

Dehmel, J.C.F., and G.T. Hong, 1994, "A Comparative Risk Assessment of Incineration and Supercritical Water Oxidation (SWCO) for Liquid Mixed Water," Proceedings of the TwentySeventh Mid-Year Topical Meeting of the Health Physics Society, Albany, New York, February 1316, 1994.

DOE. See U.S. Department of Energy.

Drez, P., 1993, personal communication, Drez Environmental Associates, Albuquerque, N.M., Oct.

EG\&G Idaho, Inc., 1994, Data Collection on Existing and Planned/Approved Waste Management Facilities in Support of the EM PEIS, Revision 1, Draft, EG\&G Idaho, Inc., Idaho Falls, Idaho, March 16.

Feizollahi, F., and D. Shropshire, 1992, Waste Management Facilities Cost Information, EGG-WTD-10443 and -92046, EG\&G Idaho, Inc., Idaho Falls, Idaho, Oct.

Freeman, H.M., 1988, Standard Handbook of Hazardous Waste Treatment and Disposal, McGraw-Hill, Inc., New York.

Gillins, R.L., et al., 1993, Mixed Waste Integrated Program Interim Evaluation Report on Thermal Treatment Technologies, DOE/MWIP-2, Oak Ridge National Laboratory, Oak Ridge, Tenn., Feb.

Lazaro, M., 1994, "Recommended Hazardous Waste Incinerator Emissions Factors in Support of Criterion Air Pollutant Air Quality Impact Assessments in the PEIS," memorandum from Lazaro, Environmental Assessment Division, Argonne National Laboratory, Argonne, Ill., to H. Avci, Environmental Assessment Division, Aug. 5.

Thompson, T.K., 1992, Mixed Waste Treatment Project: Functional and Operational Requirements for an Integrated Facility, Los Alamos National Laboratory, Los Alamos, N.M., Aug. 30. 
U.S. Department of Energy, 1982, Radioactive Waste Management, DOE Order 5820.1, Washington, D.C., September 30 (updated by DOE Order 5820.2 in 1984 and by DOE Order 5820.2A in 1988).

U.S. Department of Energy, 1988, Radioactive Waste Management, DOE Order 5820.2A, Washington, D.C., Sept. 26.

U.S. Department of Energy, 1990, Waste Isolation Pilot Plant No-Migration Variance Petition, DOE/RW-0006, Revision 8, Oct.

U.S. Department of Energy, 1991a, Transuranic Waste Acceptance Criteria for the Waste Isolation Pilot Plant, WIPP-DOE-069, Revision 4.0, Carlsbad, N.M., Dec.

U.S. Department of Energy, 1991b, Radionuclide Inventory for the Waste Isolation Pilot Plant, Draft, DOE/WIPP 91-058, Revision 0, Carlsbad, N.M.

U.S. Department of Energy, 1992a, Integrated Data Base for 1992: U.S. Spent Fuel and Radioactive Waste Inventories, Projections, and Characteristics, DOE/RW-006, Revision 8, Oak Ridge National Laboratory, Oak Ridge, Tenn.

U.S. Department of Energy, 1992b, Environmental Assessment: Retrieval and Re-Storage of Transuranic Storage Area Waste at the Idaho National Engineering Laboratory, DOE/EA-0499, Washington, D.C., Feb.

U.S. Department of Energy, 1993, Interim Mixed Waste Inventory Report: Waste Streams, Treatment Capacities, and Technologies, Volumes 1-6, DOE/NBM-1100, Washington, D.C., April.

U.S. Department of Energy, 1994, Experimental Program for the Waste Isolation Pilot Plant, DOE/WIPP 94-008, Revision 0, Carlsbad, N.M., Jan.

U.S. Department of Energy, 1995a, Mixed Waste Inventory Summary Report, DOE/M96-GT-029, Washington, D.C.

U.S. Department of Energy, 1995b, Waste Isolation Pilot Plant Transuranic Waste Baseline Inventory Report, CAO-94-1005, Revision 2, Carlsbad, NM.

U.S. Department of Energy, 1996a, Final Waste Management Programmatic Environmental Impact Statement for Managing Treatment, Storage, and Disposal of Radioactive and Hazardous Waste, DOE/EIS-0200-F, Office of Environmental Management, Washington, D.C. 
U.S. Department of Energy, 1996b, Waste Isolation Pilot Plant Disposal Phase Draft Supplemental Environmental Impact Statement, DOE/EIS-0026-S2, Washington, D.C., Nov.

U.S. Department of Energy, 1996c, Storage and Disposition of Weapons-Usable Fissile Materials Draft Programmatic Environmental Impact Statement, DOE/EIS-0229-D, Washington, D.C., Feb.

U.S. Department of Energy, 1996d, Transuranic Waste Acceptance Criteria for the Waste Isolation Pilot Plant, WIPP-DOE-069, Revision 5.0, Carlsbad, NM. 
A-1

APPENDIX A:

REQUIREMENTS FOR DISPOSAL OF TRANSURANIC WASTE AT WIPP 
A-2 


\section{CONTENTS}

A.1 Waste Acceptance Criteria $\ldots \ldots \ldots \ldots \ldots \ldots \ldots \ldots \ldots \ldots \ldots \ldots \ldots \ldots$

A.2 Operations and Safety Criteria $\ldots \ldots \ldots \ldots \ldots \ldots \ldots \ldots \ldots \ldots \ldots \ldots \ldots \ldots \ldots$

A.3 Transportation Waste Package Requirements $\ldots \ldots \ldots \ldots \ldots \ldots \ldots \ldots \ldots$ A-7

A.4 Resource Conservation and Recovery Act Requirements $\ldots \ldots \ldots \ldots \ldots \ldots \ldots \ldots$ A-8

A.5 Performance Assessment $\ldots \ldots \ldots \ldots \ldots \ldots \ldots \ldots \ldots \ldots \ldots \ldots \ldots \ldots \ldots \ldots$

A.6 Waste Characterization $\ldots \ldots \ldots \ldots \ldots \ldots \ldots \ldots \ldots \ldots \ldots \ldots \ldots \ldots$ A.$\ldots \ldots$

A.6.1 Operations and Safety Requirements $\ldots \ldots \ldots \ldots \ldots \ldots \ldots \ldots \ldots \ldots$ A-9

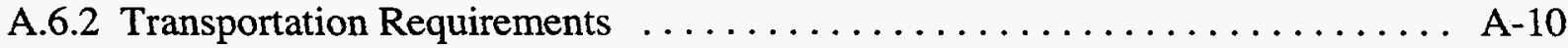

A.6.3 Resource Conservation and Recovery Act Requirements . . . . . . . . . . A A-11

A.6.4 Performance Assessment Requirements . . . . . . . . . . . . . . A-12

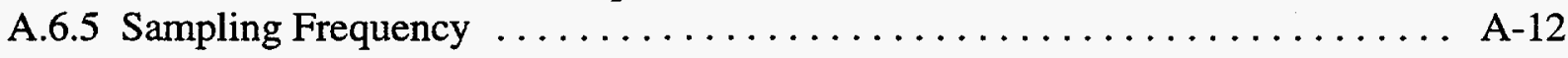

A.7 Performance-Based Waste Acceptance Criteria $\ldots \ldots \ldots \ldots \ldots \ldots \ldots \ldots$ A-13

A.8 References $\ldots \ldots \ldots \ldots \ldots \ldots \ldots \ldots \ldots \ldots \ldots \ldots \ldots \ldots \ldots \ldots \ldots \ldots \ldots$

\section{TABLES}

A.1 Frequency of Nonconformances in TRUW Retrievably Stored at RFETS . . . . . . . A-10

A.2 Assumptions for Waste Characterization Sampling $\ldots \ldots \ldots \ldots \ldots \ldots \ldots \ldots$ A-12 


\section{APPENDIX A: \\ REQUIREMENTS FOR DISPOSAL OF TRANSURANIC WASTE AT WIPP}

During the late 1970s and early 1980s, the U.S. Department of Energy (DOE) implemented initial disposal decisions at the Waste Isolation Pilot Plant (WIPP) near Carlsbad, New Mexico. Under then-existing regulations, DOE was responsible for demonstrating to the stakeholders that DOE facilities can safely handle, transport, and dispose of waste in WIPP. Regulatory requirements applicable to WIPP have increased in the past 10 years. Some of the requirements relevant to the Waste Management Programmatic Environmental Impact Statement (WM PEIS) analysis of transuranic waste (TRUW) are as follows (DOE 1996):

- Part 191 of Title 40 of the Code of Federal Regulations (40 CFR Part 191) Subpart B-Radioactive waste disposal standards (with revisions of Dec. 20 , 1994);

- 40 CFR Part 264-Standards promulgated by the Resource Conservation and Recovery Act (RCRA) for owners and operators of hazardous waste treatment, storage, and disposal (TSD) facilities;

- 40 CFR Part 265-RCRA interim status standards for owners and operators of hazardous waste TSD facilities;

- 40 CFR 268.6, Land Disposal Restrictions (LDRs)-Petitions to allow disposal of a waste prohibited under Subpart $C$ of Part 268; and

- The U.S. Nuclear Regulatory Commission's (NRC's) Certificate of Compliance for the Transuranic Package Transporter-II (TRUPACT-II) shipping cask (NRC 1992).

TRUW that was generated prior to implementation of the regulations listed above requires more sampling and analysis to qualify for shipment and placement in WIPP. However, because of better knowledge and documentation of the waste-generating processes, and the minimization of hazardous constituents in TRUW, waste generated in the last few years and that will be generated in the future should meet most, if not all, of the known requirements with minimal sampling and analysis.

To stabilize some TRUW forms for safe handling and transport, several waste treatment technologies are in current use at DOE's waste generator and/or storage sites. Examples are the 
solidification of liquid wastes and the immobilization of potentially respirable particulates (e.g., by mixing with Portland cement to form a concrete-like solid).

Processing beyond that necessary to meet the existing WIPP waste acceptance criteria (WAC) (revision 4; DOE 1991a) may be required if either of the following situations occurs:

- The U.S. Environmental Protection Agency (EPA) determines, after review of performance assessment calculations and associated documentation, that the proposed compliance submittal does not demonstrate isolation of the radionuclides for the 10,000-year regulatory period (58 FR 66398). In this situation, waste may have to be treated to an "intermediate level" to minimize the rate of gas generation from degradation of waste materials under anticipated long-term WIPP repository conditions.

- The DOE does not obtain a no-migration determination (indicating hazardous constituents are not expected to migrate off-site) for the disposal phase at WIPP and therefore is required to treat all mixed TRUW to meet LDRs (40 CFR Part 268).

The WM PEIS assesses these two treatment options, in addition to the option of treating to meet current WIPP-WAC (DOE 1991a).

\section{A.1 WASTE ACCEPTANCE CRITERIA}

Initial WIPP-WAC were developed in 1978 and 1979 by the Waste Acceptance Criteria Steering Committee, which generated the report, Transuranic Waste Acceptance Criteria for the Waste Isolation Pilot Plant (DOE 1980). Waste acceptance criteria were defined to provide requirements for the proper handling of TRUW at WIPP to ensure adequate protection of public health and worker safety.

A series of revisions consistent with the intent of the original WIPP-WAC (DOE 1980) were subsequently published to incorporate the results of ongoing project activities and comments and suggestions from others. Revision 1 (DOE 1981), revision 2 (DOE 1985), revision 3 (DOE 1989), and revision 4 (DOE 1991a) reflect consultations between the New Mexico Environmental Evaluation Group, the Albuquerque Operations Office WIPP Project, and other TRUW program participants. Separate program documents were prepared in response to other requirements, such as RCRA and TRUPACT-II certification.

Revision 4 of WIPP-WAC, hereinafter referred to as "the current WAC," identifies and consolidates all existing criteria and requirements that regulate the safe handling and preparation of 
TRUW packages transported and placed in WIPP (DOE 1991a). In the consolidation of existing criteria, a summary of the existing criteria and requirements, and identification of those that are most restrictive for meeting compliance, were provided to TRUW generator and storage sites.

The current WAC also furnish guidance for preparing documents to certify that the waste meets WAC. Waste certification must be verified (approved) by waste generators and storage sites prior to shipping TRUW to WIPP.

While some requirements and criteria are still being developed (such as those to ensure compliance with the long-term provisions outlined in 58 FR 66398), the current WAC define all current requirements and criteria for certification and acceptance of TRUW at WIPP. Future additions or revisions to the criteria may be required to meet RCRA requirements currently being established by the New Mexico Environment Department (NMED), and requirements based on results of WIPP performance studies addressing the long-term isolation of TRUW (40 CFR Part 268; 58 FR 66398).

The origins of the various criteria and requirements included in current WAC are discussed in Sections A.2 through A.7.

\section{A.2 OPERATIONS AND SAFETY CRITERIA}

Operations and Safety (O\&S) criteria issued in revisions $0,1,2,3$, and 4 of WIPP-WAC (DOE 1980, 1981, 1985, 1989, 1991a) were developed for the handling of TRUW at WIPP. The compliance criteria assist in the preparation of site-specific certification plans and detailed procedures for meeting WIPP-WAC. Site certification plans and procedures incorporate process and administrative controls and may include tests on individual waste packages.

TRUW will be routinely inspected during its production and will be examined during retrieval operations to ensure that certain requirements are met for safe handling and storage at the waste generator and storage sites and for transport and placement in WIPP.

\section{A.3 TRANSPORTATION WASTE PACKAGE REQUIREMENTS}

The TRUPACT-II shipping cask, developed and tested by DOE, has been certified by NRC in accordance with Type B packaging requirements (certified as having passed a series of drop, burn, and freeze tests as defined in 10 CFR 71.4 to demonstrate that there was no leakage) for shipment of contact-handled $(\mathrm{CH})$ TRUW from generator and storage sites to WIPP. The TRUPACT-II shipping cask will hold fourteen 55-gallon drums (two seven-packs) or two standard waste boxes of TRUW. 
Based on field and laboratory tests and the NuPac (1992) document (which defines approved methods for compliance), NRC has issued a Certificate of Compliance (NRC 1992) for the TRUPACT-II. A Certificate of Compliance is similar to a license, except that DOE has primary responsibility for the quality assurance program and for on-site audits at TRUW generator and storage sites. The DOE conducts on-site audits to monitor the maintenance of the shipping cask and the selection of CH-TRUW forms for transport in the TRUPACT-II.

Each DOE TRUW generator and storage site that will use the TRUPACT-II shipping cask is required to prepare a site-specific technical plan, "TRUPACT-II Authorized Method for Payload Control" (TRAMPAC) (NuPac 1992). The technical plan includes sufficient detail about how compliance for each payload parameter will be ensured for reviewers to understand and evaluate the compliance methodology. In addition to preparing a technical plan, sites will incorporate quality assurance requirements as quality control measures. When the transportation procedures are implemented, the site-specific TRUPACT-II payload program will be audited by DOE. A site may not transport waste in TRUPACT-II shipping casks until its compliance program passes an initial audit and DOE grants written approval. Periodic re-audits will be performed; DOE can revoke transport authority if nonconformances are detected.

Waste package requirements for transportation of remote-handled (RH) TRUW will not be finalized until the RH cask "Safety Analysis Report for Packaging" (SARP) is approved by NRC and a Certificate of Compliance is issued. A draft SARP, using preliminary criteria derived from meetings with NRC, has been completed. The SARP will be reviewed by DOE before submittal to NRC.

\section{A.4 RESOURCE CONSERVATION AND RECOVERY ACT REQUIREMENTS}

Radioactive waste containing hazardous waste is designated mixed waste and is subject to dual regulation under the Atomic Energy Act of 1954 and RCRA LDRs. A large portion of the existing DOE TRUW inventory contains hazardous constituents regulated under RCRA. The EPA has delegated authority to NMED to administer the RCRA mixed waste program within New Mexico. By incorporating federal requirements into state hazardous waste regulations, NMED can promulgate additional regulations for the management of mixed waste; however, NMED currently has not yet proposed additional regulations for the WIPP mixed waste program.

The owners/operators of TSD facilities are required under RCRA to obtain a chemical and physical characterization of the waste, so that the waste shipped to the facility can be specified on the shipping manifest (40 CFR Parts 264 and 265). These standards need to be satisfied at the generator/storage sites before shipment of waste to WIPP. Applicable RCRA requirements are described in several published documents (DOE 1991b, 1993; 55 FR 47700). These requirements are subject to change as permit conditions are issued by NMED. 


\section{A.5 PERFORMANCE ASSESSMENT}

The performance assessment criteria also are applicable to TRUW characterization in the WIPP experimental waste program. Although these experiments will now be performed at locations other than WIPP, and the final waste characterization requirements for performance assessment are yet to be determined, the performance assessment criteria in DOE (1991a) can be assumed to be an upper bound for what may be required as a result of EPA's approval of WIPP compliance documentation.

The performance assessment program addresses long-term requirements for hazardous and radionuclide constituents disposal in the WIPP repository and should demonstrate compliance with regulations for attaining adequate 10,000-year containment of hazardous and radionuclide constituents (40 CFR Part 268; 55 FR 47700; 58 FR 66398).

Constraints on the operation of WIPP are:

- The design capacity of the WIPP repository is $175,600 \mathrm{~m}^{3}\left(6.2\right.$ million $\left.\mathrm{ft}^{3}\right)$ of CH-TRUW and RH-TRUW (PL 102-579).

- The volumes of retrievably stored TRUW at DOE sites (approximately $65,000 \mathrm{~m}^{3}$ [2.3 million $\left.\mathrm{ft}^{3}\right] \mathrm{CH}$ and $4,300 \mathrm{~m}^{3}\left[150,000 \mathrm{ft}^{3}\right] \mathrm{RH}$ ) and of 25 years of projected waste $\left(41,000 \mathrm{~m}^{3}\left[1.5\right.\right.$ million $\left.\mathrm{ft}^{3}\right] \mathrm{CH}$ and $5,900 \mathrm{~m}^{3}$ $\left.\left[210,000 \mathrm{ft}^{3}\right] \mathrm{RH}\right)$ equals approximately $116,000 \mathrm{~m}^{3}\left(4.1\right.$ million $\left.\mathrm{ft}^{3}\right)$ (DOE 1991b). This is about $66 \%$ of the repository capacity.

- Future decontamination and decommissioning and environmental restoration programs may generate additional TRUW, the volumes of which cannot be accurately estimated at this time.

- Remote-handled TRUW received at WIPP shall not contain more than 5.1 million $\mathrm{Ci}$.

\section{A.6 WASTE CHARACTERIZATION}

\section{A.6.1 Operations and Safety Requirements}

Compliance of TRUW with O\&S criteria is generally met with limited sampling through a combination of process knowledge and administrative controls. For projected waste, process controls implemented at TRUW generator sites are usually adequate to meet the O\&S criteria. 
TRUW generator and storage sites use radiographic examination (usually real-time radiography) as a verification of the process controls for selected parameters. Radiography is effective for detecting noncompliant items such as excess free liquids or potentially pressurized containers.

For example, Idaho National Engineering Laboratories (INEL) has instituted a sampling and analysis program with 95 percent confidence limits for TRUW retrievably stored after 1970 . In this program, approximately one of every 100 waste containers is opened and examined. The sampling frequency is adjusted each year according to the level of compliance with O\&S criteria in the previous year's sampling. The sampling frequency required to meet the $O \& S$ criteria is much smaller than that anticipated for other parts of the WAC certification process. Table A.1 summarizes anticipated frequencies of nonconformances in solid process residues and debris wastes estimated from the INEL sampling and analysis performed on TRUW retrievably stored at the Rocky Flats Environmental Technology Site (RFETS).

\section{A.6.2 Transportation Requirements}

Certification requirements for TRUW to be shipped in TRUPACT-II containers are in many cases either (1) more than or more restrictive than O\&S criteria, or (2) added to O\&S criteria. The frequency of sampling and analysis required for TRUPACT-II certification is expected to be greater than needed to meet O\&S criteria, but less than expected to meet all RCRA characterization requirements. Most nonconformances for transportation are due to higher-than-permitted wattage (heat from decay of radionuclides) in waste containers than allowed by NRC for TRUPACT-II.

TABLE A.1 Frequency of Nonconformances in TRUW Retrievably Stored at RFETS

\begin{tabular}{lcc}
\hline \multicolumn{1}{c}{ Parameter } & $\begin{array}{c}\text { Solid Process } \\
\text { Residues }\end{array}$ & Debris Wastes \\
\hline Liquids & $17 \%$ & $8 \%$ \\
Particulates & $6 \%$ & $4 \%$ \\
Criticality & $1 \%^{\mathrm{a}}$ & $1 \%{ }^{\mathrm{a}}$ \\
Pressured containers & $0 \%$ & $1 \%$ \\
Wattage & $18 \%$ & $41 \%$ \\
\hline
\end{tabular}

a Exceeds allowed quantity, which is well below critical mass. 


\section{A.6.3 Resource Conservation and Recovery Act Requirements}

Waste generator/storage sites will characterize mixed TRUW in accordance with the RCRA regulations discussed in Section A.4. The waste will be sampled and analyzed under a site-specific waste characterization program (DOE 1991a). A laboratory that has passed a performance demonstration program administered by DOE is required to perform the sample analyses. The DOE anticipates that characterization under RCRA for mixed TRUW can be accomplished by a combination of existing process knowledge, headspace gas sampling (sampling the gas at the top inside the container), real-time radiography, and some sampling and analysis of the solidified waste materials.

For the TRUW inventory to meet existing WIPP-WAC and external regulatory requirements, 30 percent of existing drums with solidified or selected solid waste forms would need to be sampled for total toxic metals, volatile organic compounds, and semivolatiles. This percentage represents an average sampling requirement across the affected waste forms at each site. For example, RFETS anticipates that inorganic sludges precipitated from large batches of liquids will have a much lower sampling frequency, but that liquids derived from laboratory experiments will require sampling of each drum.

The waste forms that require sampling of solid/solidified wastes for total toxic metals, volatile organic compounds, and selected semivolatiles are:

- Inorganic wastewater treatment sludge,

- Organic liquid and sludge,

- Solidified liquid,

- Inorganic process solids and soils,

- Pyrochemical salts, and

- Cation and anion exchange resins.

For DOE sites that do not highly segregate their waste (for example, the Savannah River Site), small bottles of solidified liquids (identified by real-time radiography) can occur in the drums of solid wastes. These bottles would also have to be sampled and analyzed for volatile organic compounds, toxic metals, and selected semivolatiles (DOE 1993). Drums that do not contain these bottles of solidified liquids should not require opening; however, if bottles of solidified liquids are present in drums, one or more bottles in a waste container would require sampling and analysis. 


\section{A.6.4 Performance Assessment Requirements}

At present, there are no general performance assessment waste characterization requirements over and above those required for $O \& S$, transportation, and RCRA. For this study, it is assumed that performance assessment waste characterization requirements will be no more stringent than those required by other aspects of WIPP-WAC.

Regulatory agencies may require more extensive waste characterization for performance assessment. These additional requirements may increase the cost and schedule of preparing waste for shipment and disposal in WIPP and may require use of engineered alternatives to process some waste.

\section{A.6.5 Sampling Frequency}

For TRUW to meet existing WIPP-WAC and external regulatory requirements, $50 \%$ of the existing waste containers would need to be sampled for headspace gases (Table A.2). Initially, as many as 100 percent of the waste containers may need to be sampled, until DOE can build a database establishing future sampling requirements to present to external regulators.

\section{TABLE A.2 Assumptions for Waste Characterization Sampling}

\begin{tabular}{lll}
\hline Waste Characterization Parameter & Action for Retrievably Stored Wastes & $\begin{array}{c}\text { Action for Projected } \\
\text { Wastes }\end{array}$ \\
\hline $\begin{array}{l}\text { Radioassay } \\
\text { Real-time radiography }\end{array}$ & All waste containers & All waste containers \\
$\begin{array}{l}\text { Headspace sampling for volatile } \\
\text { organic compounds }\end{array}$ & All waste containers & All waste containers \\
$\begin{array}{l}\text { Sampling of solidified waste or } \\
\text { selected solids for volatile organic } \\
\text { compounds, toxic metals, and } \\
\text { selected semivolatiles }\end{array}$ & $\begin{array}{l}50 \% \text { of waste containers } \\
\text { (30\% of waste containers }\end{array}$ & 10\% of waste containers \\
$\begin{array}{l}\text { Carbon composite filters } \\
\text { Free-liquid criteria }\end{array}$ & Will be installed on all waste containers. & 5\% of waste containers \\
& & $\begin{array}{l}\text { Will be installed in lid } \\
\text { prior to drum loading. }\end{array}$ \\
\hline
\end{tabular}

a Can be concurrent with sampling for flammable gases (if flammable gas sampling is still required after the test phase). 
As a database of sampling and analysis is developed, the sampling frequency will decrease with time. Thus, Table A.2 sampling percentages are used as averages for WM PEIS scoping calculations and planning purposes and for sizing of facilities. For small sites, the samples are shipped off-site to another laboratory. In general, headspace samples are assumed to be nonradioactive and the solid/solidified samples to be radioactive.

\section{A.7 PERFORMANCE-BASED WASTE ACCEPTANCE CRITERIA (ANTICIPATED FINAL WIPP-WAC)}

For TRUW to be acceptable at WIPP for disposal, assuming no additional requirements for long-term disposal, the waste will have to meet a series of requirements and criteria (DOE 1991a). These requirements can be divided into two groups: those that exclude some prohibited items from the waste (for example, pressurized containers, explosives, and nonradionuclide pyrophorics), and those that require the quantification of a waste parameter such that the value for a waste stream/waste package parameter falls below a regulated value (for example, wattage, criticality, excess free liquids, and concentration of volatile organic compounds in waste package headspace). The ability of TRUW, at either the waste stream or waste package level, to meet the existing criteria (DOE 1991a) is a measure of "performance." The term "performance-based WAC" is used to mean the anticipated final WIPP-WAC, including any additional requirements.

In essence, WIPP already has performance-based WAC based on existing requirements and criteria. Even under the existing WAC, it is anticipated that a large fraction of projected retrievably stored waste will require repackaging. The final performance-based WAC could be more restrictive than current criteria if a new limiting parameter is identified in the final analysis submitted by DOE to the regulatory agencies in support of its compliance package for long-term isolation of TRUW (DOE 1991a).

An example of such a scenario assessed in the WM PEIS is a treatment level (other than TRUW meeting existing WIPP-WAC or treating TRUW to LDRs) based on the premise that gas volumes generated by the long-term decomposition of TRUW may be too large to be stored in the existing void volume of the repository and might induce migration of hazardous or radioactive constituents in the waste toward the unit boundary. If this scenario is predicted from the modeling of repository processes, the performance-based WAC would then be used to define the acceptable inventory of any particular waste material allowable in WIPP. For example, if corrosion of ironbased metals is the reaction that is generating excess gas, modeling studies could be initiated to indicate what total amount of iron-based metals could be accepted at the repository. 


\section{A.8 REFERENCES}

DOE: See U.S. Department of Energy.

NRC: See U.S. Nuclear Regulatory Commission.

Nuclear Packaging, Inc, 1992, Safety Analysis Report for the TRUPACT-II Shipping Package, Rev. 12, Seattle, Wash., Sept.

NuPac: See Nuclear Packaging, Inc.

U.S. Department of Energy, 1980, Transuranic Waste Acceptance Criteria for the Waste Isolation Pilot Plant, WIPP-DOE-069, Rev. 0, Carlsbad, N.M., May.

U.S. Department of Energy, 1981, Transuranic Waste Acceptance Criteria for the Waste Isolation Pilot Plant, WIPP-DOE-069, Rev. 1.0., Carlsbad, N.M., Sept.

U.S. Department of Energy, 1985, Transuranic Waste Acceptance Criteria for the Waste Isolation Pilot Plant, WIPP-DOE-069, Rev. 2.0, Carlsbad, N.M., Sept.

U.S. Department of Energy, 1989, Transuranic Waste Acceptance Criteria for the Waste Isolation Pilot Plant, WIPP-DOE-069, Rev. 3.0, Carlsbad, N.M., Jan.

U.S. Department of Energy, 1991a, Transuranic Waste Acceptance Criteria for the Waste Isolation Pilot Plant, WIPP-DOE-069, Rev. 4.0, Carlsbad, N.M., Dec.

U.S. Department of Energy, 1991b, Waste Isolation Pilot Plant Resource Conservation and Recovery Act Part A Permit Application, Carlsbad, N.M., Jan.

U.S. Department of Energy, 1993, Resource Conservation and Recovery Act Part B Permit Application, DOE/WIPP 91-005, Rev. 3, Carlsbad, N.M.

U.S. Department of Energy, 1996, Final Waste Management Programmatic Environmental Impact Statement for Managing Treatment, Storage, and Disposal of Radioactive and Hazardous Waste, DOE/EIS-0200-F, Office of Environmental Management, Washington, D.C.

U.S. Nuclear Regulatory Commission, 1992, Nuclear Packaging, Inc., Application, Certificate of Compliance No. 9218, Rev. 4, Washington, D.C., Nov. 


\section{$B-1$}

\section{APPENDIX B:}

ADDITIONAL WASTE LOADS AND AIR RELEASES FOR TRUW MANAGEMENT ALTERNATIVES 
B-2

I

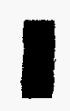

I

I

I



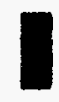

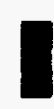

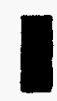

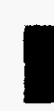

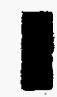



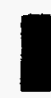

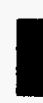

,

I

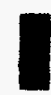

I 


\section{TABLES}

B.1 Projected Waste Loads and Release Profiles by Site in CH-TRUW

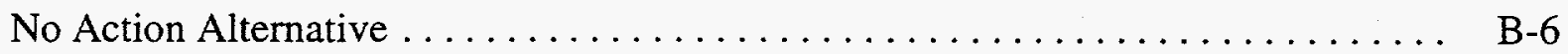

B.2 Projected Waste Loads and Release Profiles by Site in CH-TRUW Decentralized/Treatment to Meet WIPP-WAC/10 Sites Alternative

B.3 Projected Waste Loads and Release Profiles by Site in CH-TRUW Regionalized/Intermediate Treatment/Five Sites Alternative

B.4 Projected Waste Loads and Release Profiles by Site in CH-TRUW Regionalized/Treatment to LDRs/Five Sites Alternative $\ldots \ldots \ldots \ldots \ldots \ldots \ldots$ B-18

B.5 Projected Waste Loads and Release Profiles by Site in CH-TRUW Regionalized/Treatment to LDRs/Three Sites Alternative

B.6 Projected Waste Load and Release Profiles by Site in CH-TRUW Centralized/Treatment to LDRs/One Site Alternative

B.7 Projected Waste Loads and Release Profiles by Site in RH-TRUW No Action Alternative

B.8 Projected Waste Loads and Release Profiles by Site in RH-TRUW Decentralized/Treatment to WIPP-WAC/Six Sites Alternative

B.9 Projected Waste Loads and Release Profiles by Site in RH-TRUW Regionalized/Intermediate Treatment/Two Sites Alternative

B.10 Projected Waste Loads and Release Profiles by Site in RH-TRUW Regionalized/Treatment to LDRs/Two Sites Alternative . 


\section{APPENDIX B:}

\section{ADDITIONAL WASTE LOADS AND AIR RELEASES FOR TRUW MANAGEMENT ALTERNATIVES}

It is assumed that the Waste Isolation Pilot Plant (WIPP) will accept transuranic waste (TRUW) for disposal from 1998 until 2018. Based on the estimated quantities of waste to be disposed, the acceptance rate for waste will average $7,080 \mathrm{~m}^{3} / \mathrm{yr}\left(250,000 \mathrm{ft}^{3}\right)$ for 20 years. Because WIPP waste acceptance criteria (WAC) may change over time, the U.S. Department of Energy's Waste Management (WM) Programmatic Environmental Impact Statement (PEIS) analyses consider three levels of treatment: (1) current WIPP criteria, (2) an intermediate treatment using engineered alternatives, and (3) treatment to RCRA Land Disposal Restrictions (LDRs) to bound the impacts of processing, treating, and shipping TRUW to WIPP for disposal.

These three levels of treatment are considered in the WM PEIS to accommodate a range of waste characteristics and WM PEIS program analysis objectives. The minimum level of treatment involves simply processing and packaging TRUW to meet current WIPP-WAC. The intermediate level of treatment treats TRUW to reduce the rate or the potential of gas generation in WIPP, in addition to meeting WIPP-WAC. The more extensive level of treatment treats all hazardous constituents in mixed TRUW to meet RCRA LDRs.

Three intersite treatment configurations are considered in the WM PEIS. TRUW from individual sites may be sent to regional centers for treatment (Regional configuration); it may be treated on the site where it was generated (Decentralized configuration); or it may be sent from all sites to WIPP for treatment (Centralized configuration). All treated TRUW is then shipped to WIPP for disposal.

Feasible options for the treatment technologies, treatment levels, and siting configurations of TRUW management are combined into six alternatives for evaluation in the WM PEIS. Two scenarios in which no treatment or disposal action is taken, the "no action" alternatives for contacthandled TRUW and remote-handled TRUW, are included in the evaluation.

Air releases from an operation associated with a TRUW treatment technology are estimated by multiplying unit release fractions by the corresponding waste load to be treated with that technology under a given TRUW management alternative. Total air releases associated with a site under a given TRUW management alternative are estimated by summing releases from all process operations for all TRUW treatment trains employed at that site.

Waste load profiles and estimated total air releases are presented in Tables B.1 through B.10 for the TRUW management alternatives evaluated in the WM PEIS. 
TABLE B.1 Projected Waste Loads and Release Profiles by Site in CH-TRUW No Action Alternative

\begin{tabular}{|c|c|c|c|c|c|}
\hline \multicolumn{3}{|c|}{ Radiological Profile } & \multicolumn{3}{|c|}{ Chemical Profile } \\
\hline Radionuclide & $\begin{array}{c}\text { Total } \\
(\mathrm{Ci} / \mathrm{yr}) \\
\end{array}$ & $\begin{array}{l}\text { Released } \\
(\mathrm{Ci} / \mathrm{yr})\end{array}$ & Contaminant & $\begin{array}{c}\text { Total } \\
(\mathrm{kg} / \mathrm{yr}) \\
\end{array}$ & $\begin{array}{c}\text { Released } \\
(\mathrm{kg} / \mathrm{yr})\end{array}$ \\
\hline \multicolumn{6}{|c|}{$\begin{array}{l}\text { Treatment Site: ANL-E } \\
\text { Volume: } 4.7 \times 10^{1} \mathrm{~m}^{3} / \mathrm{yr}\end{array}$} \\
\hline U-235 & $1.1 \times 10^{-4}$ & $2.3 \times 10^{-14}$ & Carbon tetrachloride & $7.8 \times 10^{-1}$ & $7.8 \times 10^{-6}$ \\
\hline$U-238$ & $3.2 \times 10^{-5}$ & $6.4 \times 10^{-15}$ & Methyl alcohol & $5.6 \times 10^{-1}$ & $5.6 \times 10^{-6}$ \\
\hline $\mathrm{Pu}-239$ & $3.4 \times 10^{1}$ & $6.9 \times 10^{-9}$ & Butanol & $3.6 \times 10^{-1}$ & $3.6 \times 10^{-6}$ \\
\hline Pu-240 & 7.5 & $1.5 \times 10^{-9}$ & Methyl chloroform & 1.2 & $1.2 \times 10^{-5}$ \\
\hline \multirow[t]{8}{*}{$\mathrm{Pu}-241$} & $2.1 \times 10^{2}$ & $4.1 \times 10^{-8}$ & Methylene chloride & 2.9 & $2.9 \times 10^{-5}$ \\
\hline & & & $\begin{array}{l}\text { 1,1,2-trichloro-1,2,2- } \\
\text { trifluoroethane }\end{array}$ & 1.2 & $1.2 \times 10^{-5}$ \\
\hline & & & Ethyl benzene & $5.1 \times 10^{-1}$ & $5.1 \times 10^{-6}$ \\
\hline & & & Toluene & $5.2 \times 10^{-1}$ & $5.1 \times 10^{-6}$ \\
\hline & & & Xylene & $5.6 \times 10^{-1}$ & $5.6 \times 10^{-6}$ \\
\hline & & & Cadmium & $3.6 \times 10^{-1}$ & $7.2 \times 10^{-11}$ \\
\hline & & & Lead & $7.5 \times 10^{-1}$ & $1.5 \times 10^{-10}$ \\
\hline & & \multicolumn{2}{|c|}{$\begin{array}{l}\text { Treatment Site: Hanford } \\
\text { Volume: } 7.9 \times 10^{2} \mathrm{~m}^{3} / \mathrm{yr}\end{array}$} & . & \\
\hline C-14 & $1.51 \times 10^{-1}$ & $3.02 \times 10^{-11}$ & Carbon tetrachloride & 9.33 & $9.33 \times 10^{-5}$ \\
\hline Sr-90 & $6.54 \times 10^{1}$ & $1.31 \times 10^{-8}$ & Methyl alcohol & $2.96 \times 10^{-1}$ & $2.96 \times 10^{-6}$ \\
\hline Cs-137 & $6.45 \times 10^{1}$ & $1.29 \times 10^{-8}$ & Butanol & $1.91 \times 10^{-1}$ & $1.91 \times 10^{-6}$ \\
\hline $\mathrm{Pm}-147$ & $4.51 \times 10^{-3}$ & $9.03 \times 10^{-13}$ & Methyl chloroform & $1.50 \times 10^{1}$ & $1.50 \times 10^{-4}$ \\
\hline Ra-228 & $5.29 \times 10^{-3}$ & $1.06 \times 10^{-12}$ & Methylene chloride & $6.34 \times 10^{1}$ & $6.34 \times 10^{-4}$ \\
\hline Th-229 & $1.23 \times 10^{-2}$ & $2.47 \times 10^{-12}$ & 1,1,2-trichloro-1,2,2- & $2.72 \times 10^{1}$ & $2.72 \times 10^{-4}$ \\
\hline Th-232 & $6.34 \times 10^{-3}$ & $1.27 \times 10^{-12}$ & trifluoroethane & & \\
\hline U-233 & 7.55 & $1.51 \times 10^{-9}$ & Ethyl benzene & $2.69 \times 10^{-1}$ & $2.69 \times 10^{-6}$ \\
\hline U-234 & 5.08 & $1.02 \times 10^{-9}$ & Toluene & $2.69 \times 10^{-1}$ & $2.69 \times 10^{-6}$ \\
\hline U-235 & $1.62 \times 10^{-1}$ & $3.23 \times 10^{-11}$ & Xylene & $5.93 \times 10^{-1}$ & $5.93 \times 10^{-6}$ \\
\hline $\mathrm{U}-238$ & $5.53 \times 10^{-1}$ & $1.11 \times 10^{-10}$ & Cadmium & $1.91 \times 10^{-1}$ & $3.83 \times 10^{-11}$ \\
\hline $\mathrm{Pu}-238$ & $7.60 \times 10^{3}$ & $1.52 \times 10^{-6}$ & Mercury & 2.80 & $5.60 \times 10^{-10}$ \\
\hline Pu-239 & $2.48 \times 10^{3}$ & $4.96 \times 10^{-7}$ & Lead & $3.10 \times 10^{2}$ & $6.20 \times 10^{-8}$ \\
\hline $\mathrm{Pu}-240$ & $5.80 \times 10^{2}$ & $1.16 \times 10^{-7}$ & & & \\
\hline $\mathrm{Pu}-241$ & $3.57 \times 10^{3}$ & $7.14 \times 10^{-7}$ & & & \\
\hline Am-241 & $4.47 \times 10^{2}$ & $8.94 \times 10^{-8}$ & & & \\
\hline $\mathrm{Cm}-244$ & 6.45 & $1.29 \times 10^{-9}$ & & & \\
\hline $\mathrm{Cm}-245$ & 1.59 & $3.17 \times 10^{-10}$ & & & \\
\hline Cf -252 & 3.33 & $6.66 \times 10^{-10}$ & & & \\
\hline
\end{tabular}


TABLE B.1 (Cont.)

\begin{tabular}{|c|c|c|c|c|c|}
\hline \multicolumn{3}{|c|}{ Radiological Profile } & \multicolumn{3}{|c|}{ Chemical Profile } \\
\hline Radionuclide & $\begin{array}{c}\text { Total } \\
(\mathrm{Ci} / \mathrm{yr}) \\
\end{array}$ & $\begin{array}{c}\text { Released } \\
(\mathrm{Ci} / \mathrm{yr}) \\
\end{array}$ & Contaminant & $\begin{array}{c}\text { Total } \\
(\mathrm{kg} / \mathrm{yr})\end{array}$ & $\begin{array}{c}\text { Released } \\
(\mathrm{kg} / \mathrm{yr})\end{array}$ \\
\hline \multicolumn{6}{|c|}{$\begin{array}{l}\text { Treatment Site: INEL } \\
\text { Volume: } 1.4 \times 10^{1} \mathrm{~m}^{3} / \mathrm{yr}\end{array}$} \\
\hline $\mathrm{Sr}-90$ & $1.9 \times 10^{-1}$ & $3.9 \times 10^{-11}$ & Carbon tetrachloride & $1.9 \times 10^{1}$ & $1.9 \times 10^{-4}$ \\
\hline Ru-106 & $2.5 \times 10^{-4}$ & $5.0 \times 10^{-14}$ & Methyl alcohol & $2.6 \times 10^{-2}$ & $2.6 \times 10^{-7}$ \\
\hline Cs-137 & $2.5 \times 10^{-1}$ & $5.0 \times 10^{-11}$ & Butanol & $1.7 \times 10^{-2}$ & $1.7 \times 10^{-7}$ \\
\hline $\mathrm{Ce}-144$ & $1.8 \times 10^{-3}$ & $3.6 \times 10^{-13}$ & Methyl chloroform & $5.5 \times 10^{1}$ & $5.5 \times 10^{-4}$ \\
\hline Pm-147 & $8.1 \times 10^{-1}$ & $1.6 \times 10^{-10}$ & Methylene chloride & 4.1 & $4.1 \times 10^{-5}$ \\
\hline Th-232 & $1.1 \times 10^{-4}$ & $2.1 \times 10^{-14}$ & 1,1,2-trichloro-1,2,2- & $1.9 \times 10^{1}$ & $1.9 \times 10^{-4}$ \\
\hline U-235 & $5.3 \times 10^{-5}$ & $1.1 \times 10^{-14}$ & trifluoroethane & & \\
\hline U-238 & $4.5 \times 10^{-5}$ & $8.9 \times 10^{-15}$ & Ethyl benzene & $2.4 \times 10^{-2}$ & $2.4 \times 10^{-7}$ \\
\hline Np-237 & $2.1 \times 10^{-4}$ & $4.2 \times 10^{-14}$ & Toluene & $2.4 \times 10^{-2}$ & $2.4 \times 10^{-7}$ \\
\hline $\mathrm{Pu}-238$ & $2.1 \times 10^{1}$ & $4.2 \times 10^{-9}$ & Xylene & $5.3 \times 10^{-2}$ & $5.3 \times 10^{-7}$ \\
\hline Pu-239 & $1.3 \times 10^{1}$ & $2.6 \times 10^{-9}$ & Cadmium & $1.7 \times 10^{-2}$ & $3.4 \times 10^{-12}$ \\
\hline Pu-240 & 3.2 & $6.4 \times 10^{-10}$ & Mercury & $1.8 \times 10^{-1}$ & $3.6 \times 10^{-11}$ \\
\hline Pu-241 & $9.4 \times 10^{1}$ & $1.9 \times 10^{-8}$ & Lead & $7.2 \times 10^{1}$ & $1.4 \times 10^{-8}$ \\
\hline $\mathrm{Pu}-242$ & $3.4 \times 10^{-4}$ & $6.7 \times 10^{-14}$ & & & \\
\hline Am-241 & $2.8 \times 10^{1}$ & $5.6 \times 10^{-9}$ & & & \\
\hline $\mathrm{Cm}-244$ & $3.6 \times 10^{-1}$ & $7.3 \times 10^{-11}$ & & & \\
\hline $\mathrm{Cf}-252$ & $2.1 \times 10^{-5}$ & $4.2 \times 10^{-15}$ & & & \\
\hline \multicolumn{6}{|c|}{$\begin{array}{l}\text { Treatment Site: LANL } \\
\text { Volume: } 1.3 \times 10^{2} \mathrm{~m}^{3} / \mathrm{yr}\end{array}$} \\
\hline $\mathrm{Sr}-90$ & 3.6 & $7.3 \times 10^{-10}$ & Carbon tetrachloride & 5.5 & $5.5 \times 10^{-5}$ \\
\hline$Y-90$ & 3.6 & $7.3 \times 10^{-10}$ & Methyl alcohol & $1.3 \times 10^{-1}$ & $1.3 \times 10^{-6}$ \\
\hline Cs-137 & 3.6 & $7.3 \times 10^{-10}$ & Butanol & $8.5 \times 10^{-2}$ & $8.5 \times 10^{-7}$ \\
\hline $\mathrm{Ba}-137 \mathrm{~m}$ & 2.4 & $4.8 \times 10^{-10}$ & Methyl chloroform & 8.6 & $8.6 \times 10^{-5}$ \\
\hline Pm-147 & 2.8 & $5.5 \times 10^{-10}$ & Methylene chloride & $3.9 \times 10^{1}$ & $3.9 \times 10^{-4}$ \\
\hline U-235 & $6.1 \times 10^{-4}$ & $1.2 \times 10^{-13}$ & 1,1,2-trichloro-1,2,2- & $1.6 \times 10^{1}$ & $1.6 \times 10^{-4}$ \\
\hline U-238 & $3.4 \times 10^{-3}$ & $6.8 \times 10^{-13}$ & trifluoroethane & & \\
\hline Pu-238 & $2.0 \times 10^{3}$ & $4.0 \times 10^{-7}$ & Ethyl benzene & $1.2 \times 10^{-1}$ & $1.2 \times 10^{-6}$ \\
\hline Pu-239 & $7.6 \times 10^{2}$ & $1.5 \times 10^{-7}$ & Toluene & $1.2 \times 10^{-1}$ & $1.2 \times 10^{-6}$ \\
\hline Pu-240 & $2.5 \times 10^{2}$ & $5.0 \times 10^{-8}$ & Xylene & $2.6 \times 10^{-1}$ & $2.6 \times 10^{-6}$ \\
\hline $\mathrm{Pu}-241$ & $1.1 \times 10^{4}$ & $2.1 \times 10^{-6}$ & Cadmium & $8.5 \times 10^{-2}$ & $1.7 \times 10^{-11}$ \\
\hline $\mathrm{Pu}-242$ & $3.1 \times 10^{-2}$ & $6.3 \times 10^{-12}$ & Mercury & 1.8 & $3.5 \times 10^{-10}$ \\
\hline Am-241 & $2.3 \times 10^{3}$ & $4.5 \times 10^{-7}$ & Lead & $1.9 \times 10^{2}$ & $3.9 \times 10^{-8}$ \\
\hline
\end{tabular}




\section{TABLE B.1 (Cont.)}

\begin{tabular}{|c|c|c|c|c|c|}
\hline \multicolumn{3}{|c|}{ Radiological Profile } & \multicolumn{3}{|c|}{ Chemical Profile } \\
\hline Radionuclide & $\begin{array}{c}\text { Total } \\
(\mathrm{Ci} / \mathrm{yr})\end{array}$ & $\begin{array}{c}\text { Released } \\
(\mathrm{Ci} / \mathrm{yr})\end{array}$ & Contaminant & $\begin{array}{c}\text { Total } \\
(\mathrm{kg} / \mathrm{yr}) \\
\end{array}$ & $\begin{array}{c}\text { Released } \\
(\mathrm{kg} / \mathrm{yr})\end{array}$ \\
\hline \multicolumn{6}{|c|}{$\begin{array}{l}\text { Treatment Site: } \mathrm{LBL} \\
\text { Volume: } 1.0 \times 10^{-2} \mathrm{~m}^{3} / \mathrm{yr}\end{array}$} \\
\hline $\mathrm{Pu}-238$ & $8.3 \times 10^{-4}$ & $1.7 \times 10^{-13}$ & Carbon tetrachloride & $1.4 \times 10^{-3}$ & $1.4 \times 10^{-8}$ \\
\hline Pu-239 & $1.7 \times 10^{-2}$ & $3.4 \times 10^{-12}$ & Methyl chloroform & $2.2 \times 10^{-3}$ & $2.2 \times 10^{-8}$ \\
\hline Pu-240 & $5.0 \times 10^{-3}$ & $1.0 \times 10^{-12}$ & Methylene chloride & $8.8 \times 10^{-4}$ & $8.8 \times 10^{-9}$ \\
\hline Pu-241 & $1.2 \times 10^{-1}$ & $2.4 \times 10^{-11}$ & 1,1,2-trichloro-1,2,2- & $2.0 \times 10^{-3}$ & $2.0 \times 10^{-8}$ \\
\hline $\mathrm{Pu}-242$ & $5.3 \times 10^{-7}$ & $1.1 \times 10^{-16}$ & trifluoroethane & & \\
\hline Am-241 & $5.5 \times 10^{-3}$ & $1.1 \times 10^{-12}$ & Lead & $2.2 \times 10^{-3}$ & $4.4 \times 10^{-13}$ \\
\hline \multicolumn{6}{|c|}{$\begin{array}{l}\text { Treatment Site: LLNL } \\
\text { Volume: } 7.4 \times 10^{1} \mathrm{~m}^{3} / \mathrm{yr}\end{array}$} \\
\hline $\mathrm{Pu}-238$ & 6.1 & $1.2 \times 10^{-9}$ & Carbon tetrachloride & $5.3 \times 10^{2}$ & $5.3 \times 10^{-3}$ \\
\hline Pu-239 & $1.3 \times 10^{2}$ & $2.5 \times 10^{-8}$ & Methyl alcohol & $2.7 \times 10^{-1}$ & $2.7 \times 10^{-6}$ \\
\hline $\mathrm{Pu}-240$ & $3.7 \times 10^{1}$ & $7.4 \times 10^{-9}$ & Butanol & $1.7 \times 10^{-1}$ & $1.7 \times 10^{-6}$ \\
\hline Pu-241 & $8.9 \times 10^{2}$ & $1.8 \times 10^{-7}$ & Methyl chloroform & $1.6 \times 10^{3}$ & $1.6 \times 10^{-2}$ \\
\hline Pu-242 & $3.9 \times 10^{-3}$ & $7.8 \times 10^{-13}$ & Methylene chloride & $1.1 \times 10^{1}$ & $1.1 \times 10^{-4}$ \\
\hline \multirow[t]{5}{*}{$A m-241$} & $4.1 \times 10^{1}$ & $8.1 \times 10^{-9}$ & $\begin{array}{l}\text { 1,1,2-trichloro-1,2,2- } \\
\text { trifluoroethane }\end{array}$ & $5.3 \times 10^{2}$ & $5.3 \times 10^{-3}$ \\
\hline & & & Ethyl benzene & $2.4 \times 10^{-1}$ & $2.4 \times 10^{-6}$ \\
\hline & & & Toluene & $2.4 \times 10^{-1}$ & $2.4 \times 10^{-6}$ \\
\hline & & & Xylene & $2.4 \times 10^{-1}$ & $2.4 \times 10^{-6}$ \\
\hline & & & Cadmium & $1.7 \times 10^{-1}$ & $3.4 \times 10^{-11}$ \\
\hline \multicolumn{6}{|c|}{$\begin{array}{l}\text { Treatment Site: RFETS } \\
\text { Volume: } 2.4 \times 10^{2} \mathrm{~m}^{3} / \mathrm{yr}\end{array}$} \\
\hline $\mathrm{U}-235$ & $3.8 \times 10^{-5}$ & $7.5 \times 10^{-15}$ & Carbon tetrachloride & 3.4 & $3.4 \times 10^{-5}$ \\
\hline $\mathrm{Pu}-238$ & $1.4 \times 10^{1}$ & $2.9 \times 10^{-9}$ & Methyl alcohol & $6.4 \times 10^{-1}$ & $6.4 \times 10^{-6}$ \\
\hline Pu-239 & $3.9 \times 10^{2}$ & $7.9 \times 10^{-8}$ & Butanol & $4.1 \times 10^{-1}$ & $4.1 \times 10^{-6}$ \\
\hline $\mathrm{Pu}-240$ & $9.6 \times 10^{1}$ & $1.9 \times 10^{-8}$ & Methyl chloroform & $1.0 \times 10^{1}$ & $1.0 \times 10^{-4}$ \\
\hline Pu-241 & $2.6 \times 10^{3}$ & $5.2 \times 10^{-7}$ & Methylene chloride & $4.9 \times 10^{1}$ & $4.9 \times 10^{-4}$ \\
\hline Pu-242 & $2.8 \times 10^{-3}$ & $5.6 \times 10^{-13}$ & 1,1,2-trichloro-1,2,2- & $2.4 \times 10^{1}$ & $2.4 \times 10^{-4}$ \\
\hline \multirow[t]{7}{*}{ Am-241 } & $4.2 \times 10^{2}$ & $8.5 \times 10^{-8}$ & trifluoroethane & & \\
\hline & & & Ethyl benzene & $5.8 \times 10^{-1}$ & $5.8 \times 10^{-6}$ \\
\hline & & & Toluene & $5.8 \times 10^{-1}$ & $5.8 \times 10^{-6}$ \\
\hline & & & Xylene & 1.3 & $1.3 \times 10^{-5}$ \\
\hline & & & Cadmium & $4.1 \times 10^{-1}$ & $8.2 \times 10^{-11}$ \\
\hline & & & Mercury & 2.3 & $4.6 \times 10^{-10}$ \\
\hline & & & Lead & $2.5 \times 10^{4}$ & $5.0 \times 10^{-6}$ \\
\hline
\end{tabular}


TABLE B.1 (Cont.)

\begin{tabular}{|c|c|c|c|c|c|}
\hline \multicolumn{3}{|c|}{ Radiological Profile } & \multicolumn{3}{|c|}{ Chemical Profile } \\
\hline Radionuclide & $\begin{array}{l}\text { Total } \\
(\mathrm{Ci} / \mathrm{yr}) \\
\end{array}$ & $\begin{array}{c}\text { Released } \\
(\mathrm{Ci} / \mathrm{yr})\end{array}$ & Contaminant & $\begin{array}{c}\text { Total } \\
(\mathrm{kg} / \mathrm{yr})\end{array}$ & $\begin{array}{c}\text { Released } \\
(\mathrm{kg} / \mathrm{yr})\end{array}$ \\
\hline \multicolumn{6}{|c|}{$\begin{array}{c}\text { Treatment Site: SRS } \\
\text { Volume: } 3.6 \times 10^{2} \mathrm{~m}^{3} / \mathrm{yr}\end{array}$} \\
\hline $\mathrm{Co}-60$ & $3.99 \times 10^{-2}$ & $7.97 \times 10^{-12}$ & Carbon tetrachloride & $4.65 \times 10^{-1}$ & $4.65 \times 10^{-6}$ \\
\hline $\mathrm{Ni}-59$ & $1.40 \times 10^{-4}$ & $2.80 \times 10^{-14}$ & Methyl chloroform & $6.98 \times 10^{-1}$ & $6.98 \times 10^{-6}$ \\
\hline $\mathrm{Ni}-63$ & $1.71 \times 10^{-2}$ & $3.41 \times 10^{-12}$ & Methylene chloride & 3.41 & $3.41 \times 10^{-5}$ \\
\hline Sr-90 & $7.82 \times 10^{-1}$ & $1.56 \times 10^{-10}$ & 1,1,2-trichloro-1,2,2 & 1.38 & $1.38 \times 10^{-5}$ \\
\hline Cs-137 & $8.42 \times 10^{-1}$ & $1.68 \times 10^{-10}$ & trifluoroethane & & \\
\hline Eu-155 & 5.92 & $1.18 \times 10^{-9}$ & Mercury & $1.55 \times 10^{-1}$ & $3.10 \times 10^{-11}$ \\
\hline $\mathrm{Ra}-228$ & $1.13 \times 10^{-3}$ & $2.27 \times 10^{-13}$ & Lead & $1.71 \times 10^{1}$ & $3.41 \times 10^{-9}$ \\
\hline Th-230 & $2.63 \times 10^{-4}$ & $5.26 \times 10^{-14}$ & & & \\
\hline Th-232 & $2.39 \times 10^{-3}$ & $4.78 \times 10^{-13}$ & & & \\
\hline U-232 & $1.00 \times 10^{-2}$ & $2.00 \times 10^{-12}$ & & & \\
\hline U-233 & $4.21 \times 10^{-1}$ & $8.41 \times 10^{-11}$ & & & \\
\hline U-234 & 2.87 & $5.73 \times 10^{-10}$ & & & \\
\hline U-235 & $6.55 \times 10^{-4}$ & $1.31 \times 10^{-13}$ & & & \\
\hline U-236 & $5.36 \times 10^{-3}$ & $1.07 \times 10^{-12}$ & & & \\
\hline U-238 & $6.39 \times 10^{-4}$ & $1.28 \times 10^{-13}$ & & & \\
\hline Np-237 & $9.63 \times 10^{-1}$ & $1.93 \times 10^{-10}$ & & & \\
\hline Pu-238 & $5.46 \times 10^{4}$ & $1.09 \times 10^{-5}$ & & & \\
\hline Pu-239 & $1.04 \times 10^{3}$ & $2.08 \times 10^{-7}$ & & & \\
\hline $\mathrm{Pu}-240$ & $2.57 \times 10^{2}$ & $5.14 \times 10^{-8}$ & & & \\
\hline Pu-241 & $6.95 \times 10^{3}$ & $1.39 \times 10^{-6}$ & & & \\
\hline$A m-241$ & $4.22 \times 10^{2}$ & $8.43 \times 10^{-8}$ & & & \\
\hline $\mathrm{Cm}-244$ & $8.36 \times 10^{1}$ & $1.67 \times 10^{-8}$ & & & \\
\hline \multicolumn{6}{|c|}{$\begin{array}{l}\text { Treatment Site: UMC } \\
\text { Volume: } 2.0 \mathrm{~m}^{3} / \mathrm{yr}\end{array}$} \\
\hline $\mathrm{Pu}-238$ & $1.7 \times 10^{-1}$ & $3.3 \times 10^{-11}$ & Carbon tetrachloride & $2.7 \times 10^{-1}$ & $2.7 \times 10^{-6}$ \\
\hline Pu-239 & 3.4 & $6.8 \times 10^{-10}$ & Methyl chloroform & $4.4 \times 10^{-1}$ & $4.4 \times 10^{-6}$ \\
\hline $\mathrm{Pu}-240$ & 1.0 & $2.0 \times 10^{-10}$ & Methylene chloride & $1.8 \times 10^{-1}$ & $1.8 \times 10^{-6}$ \\
\hline Pu-241 & $2.4 \times 10^{1}$ & $4.8 \times 10^{-9}$ & 1,1,2-trichloro-1,2,2- & $4.0 \times 10^{-1}$ & $4.0 \times 10^{-6}$ \\
\hline $\mathrm{Pu}-242$ & $1.1 \times 10^{-4}$ & $2.1 \times 10^{-14}$ & trifluoroethane & & \\
\hline Am-241 & 1.1 & $2.2 \times 10^{-10}$ & Lead & $4.4 \times 10^{-1}$ & $8.8 \times 10^{-11}$ \\
\hline
\end{tabular}


TABLE B.2 Projected Waste Loads and Release Profiles by Site in CH-TRUW Decentralized/Treatment to Meet WIPP-WAC/10 Sites Alternative

\begin{tabular}{|c|c|c|c|c|c|}
\hline \multicolumn{3}{|c|}{ Radiological Profile } & \multicolumn{3}{|c|}{ Chemical Profile } \\
\hline Radionuclide & $\begin{array}{c}\text { Total } \\
(\mathrm{Ci} / \mathrm{yr})\end{array}$ & $\begin{array}{c}\text { Released } \\
(\mathrm{Ci} / \mathrm{yr})\end{array}$ & Contaminant & $\begin{array}{c}\text { Total } \\
(\mathrm{kg} / \mathrm{yr})\end{array}$ & $\begin{array}{c}\text { Released } \\
(\mathrm{kg} / \mathrm{yr})\end{array}$ \\
\hline \multicolumn{6}{|c|}{$\begin{array}{l}\text { Storage Site: ANL-E } \\
\text { Volume: } 9.5 \times 10^{1} \mathrm{~m}^{3} / \mathrm{yr}\end{array}$} \\
\hline U-235 & $2.3 \times 10^{-4}$ & $1.3 \times 10^{-13}$ & Carbon tetrachloride & 1.6 & $6.2 \times 10^{-5}$ \\
\hline U-238 & $6.5 \times 10^{-5}$ & $3.8 \times 10^{-14}$ & Methyl alcohol & 1.1 & $2.7 \times 10^{-5}$ \\
\hline $\mathrm{Pu}-239$ & $6.9 \times 10^{1}$ & $4.1 \times 10^{-8}$ & Butanol & $7.4 \times 10^{-1}$ & $1.7 \times 10^{-5}$ \\
\hline $\mathrm{Pu}-240$ & $1.5 \times 10^{1}$ & $8.9 \times 10^{-9}$ & Methyl chloroform & 2.5 & $9.7 \times 10^{-5}$ \\
\hline \multirow[t]{7}{*}{$\mathrm{Pu}-241$} & $4.2 \times 10^{2}$ & $2.5 \times 10^{-7}$ & Methylene chloride & 6.1 & $2.4 \times 10^{-4}$ \\
\hline & & & $\begin{array}{l}\text { 1,1,2-trichloro-1,2,2- } \\
\text { trifluoroethane }\end{array}$ & 2.5 & $9.7 \times 10^{-5}$ \\
\hline & & & Ethyl benzene & 1.0 & $4.1 \times 10^{-5}$ \\
\hline & & & Toluene & 1.0 & $4.1 \times 10^{-5}$ \\
\hline & & & Xylene & 1.2 & $4.5 \times 10^{-5}$ \\
\hline & & & Cadmium & $7.4 \times 10^{-1}$ & $4.3 \times 10^{-10}$ \\
\hline & & & Lead & 1.6 & $8.6 \times 10^{-10}$ \\
\hline \multicolumn{6}{|c|}{$\begin{array}{l}\text { Storage Site: Hanford } \\
\text { Volume: } 7.9 \times 10^{2} \mathrm{~m}^{3} / \mathrm{yr}\end{array}$} \\
\hline C-14 & $4.59 \times 10^{-1}$ & $2.03 \times 10^{-10}$ & Carbon tetrachloride & $1.90 \times 10^{1}$ & $6.00 \times 10^{-4}$ \\
\hline Sr-90 & $1.98 \times 10^{2}$ & $8.80 \times 10^{-8}$ & Methyl alcohol & $6.11 \times 10^{-1}$ & $2.40 \times 10^{-5}$ \\
\hline Cs-137 & $1.96 \times 10^{2}$ & $8.68 \times 10^{-8}$ & Butanol & $3.94 \times 10^{-1}$ & $1.55 \times 10^{-5}$ \\
\hline Pm-147 & $1.37 \times 10^{-2}$ & $6.07 \times 10^{-12}$ & Methyl chloroform & $3.05 \times 10^{1}$ & $9.79 \times 10^{-4}$ \\
\hline $\mathrm{Ra}-228$ & $1.60 \times 10^{-2}$ & $7.11 \times 10^{-12}$ & Methylene chloride & $1.29 \times 10^{2}$ & $4.02 \times 10^{-3}$ \\
\hline Th-229 & $3.75 \times 10^{-2}$ & $1.66 \times 10^{-11}$ & 1,1,2-trichloro-1,2,2- & $5.54 \times 10^{1}$ & $1.75 \times 10^{-3}$ \\
\hline Th-232 & $1.92 \times 10^{-2}$ & $8.52 \times 10^{-12}$ & trifluoroethane & & \\
\hline $\mathrm{U}-233$ & $2.29 \times 10^{1}$ & $1.02 \times 10^{-8}$ & Ethyl benzene & $5.55 \times 10^{-1}$ & $2.18 \times 10^{-5}$ \\
\hline $\mathrm{U}-234$ & $1.54 \times 10^{1}$ & $6.83 \times 10^{-9}$ & Toluene & $5.55 \times 10^{-1}$ & $2.18 \times 10^{-5}$ \\
\hline $\mathrm{U}-235$ & $4.90 \times 10^{-1}$ & $2.17 \times 10^{-10}$ & Xylene & 1.22 & $4.80 \times 10^{-5}$ \\
\hline $\mathrm{U}-238$ & 1.68 & $7.45 \times 10^{-10}$ & Cadmium & $3.94 \times 10^{-1}$ & $2.29 \times 10^{-10}$ \\
\hline $\mathrm{Pu}-238$ & $2.31 \times 10^{4}$ & $1.02 \times 10^{-5}$ & Mercury & 5.68 & $2.41 \times 10^{-9}$ \\
\hline Pu-239 & $7.54 \times 10^{3}$ & $3.34 \times 10^{-6}$ & Lead & $6.58 \times 10^{2}$ & $2.81 \times 10^{-7}$ \\
\hline Pu-240 & $1.76 \times 10^{3}$ & $7.81 \times 10^{-7}$ & & & \\
\hline $\mathrm{Pu}-241$ & $1.08 \times 10^{4}$ & $4.80 \times 10^{-6}$ & & & \\
\hline Am-241 & $1.36 \times 10^{3}$ & $6.02 \times 10^{-7}$ & & & \\
\hline $\mathrm{Cm}-244$ & $1.96 \times 10^{1}$ & $8.68 \times 10^{-9}$ & & & \\
\hline $\mathrm{Cm}-245$ & 4.81 & $2.13 \times 10^{-9}$ & & & \\
\hline Cf-252 & $1.01 \times 10^{1}$ & $4.48 \times 10^{-9}$ & & & \\
\hline
\end{tabular}


TABLE B.2 (Cont.)

\begin{tabular}{|c|c|c|c|c|c|}
\hline \multicolumn{3}{|c|}{ Radiological Profile } & \multicolumn{3}{|c|}{ Chemical Profile } \\
\hline Radionuclide & $\begin{array}{c}\text { Total } \\
(\mathrm{Ci} / \mathrm{yr}) \\
\end{array}$ & $\begin{array}{c}\text { Released } \\
(\mathrm{Ci} / \mathrm{yr})\end{array}$ & Contaminant & $\begin{array}{c}\text { Total } \\
(\mathrm{kg} / \mathrm{yr})\end{array}$ & $\begin{array}{c}\text { Released } \\
(\mathrm{kg} / \mathrm{yr})\end{array}$ \\
\hline \multicolumn{6}{|c|}{$\begin{array}{l}\text { Storage Site: INEL } \\
\text { Volume: } 3.8 \times 10^{3} \mathrm{~m}^{3} / \mathrm{yr}\end{array}$} \\
\hline $\mathrm{Sr}-90$ & $5.3 \times 10^{1}$ & $3.1 \times 10^{-8}$ & Carbon tetrachloride & $6.3 \times 10^{3}$ & $2.6 \times 10^{-1}$ \\
\hline Ru-106 & $6.9 \times 10^{-2}$ & $3.9 \times 10^{-11}$ & Methyl alcohol & 8.4 & $5.0 \times 10^{-4}$ \\
\hline Cs- 137 & $6.9 \times 10^{1}$ & $3.9 \times 10^{-8}$ & Butanol & 5.4 & $3.3 \times 10^{-4}$ \\
\hline $\mathrm{Ce}-144$ & $4.9 \times 10^{-1}$ & $2.9 \times 10^{-10}$ & Methyl chloroform & $1.9 \times 10^{4}$ & $7.8 \times 10^{-1}$ \\
\hline $\mathrm{Pm}-147$ & $2.2 \times 10^{2}$ & $1.3 \times 10^{-7}$ & methylene chloride & $1.1 \times 10^{3}$ & $4.4 \times 10^{-2}$ \\
\hline Th-232 & $2.9 \times 10^{-2}$ & $1.7 \times 10^{-11}$ & 1,1,2-trichloro-1,2,2- & $6.6 \times 10^{3}$ & $2.8 \times 10^{-1}$ \\
\hline U-233 & $7.9 \times 10^{1}$ & $4.6 \times 10^{-8}$ & trifluoroethane & & \\
\hline U-235 & $1.4 \times 10^{-2}$ & $8.3 \times 10^{-12}$ & Ethyl benzene & 7.7 & $3.2 \times 10^{-4}$ \\
\hline U-238 & $1.2 \times 10^{-2}$ & $6.9 \times 10^{-12}$ & Toluene & 7.7 & $3.2 \times 10^{-4}$ \\
\hline Np-237 & $5.7 \times 10^{-2}$ & $3.3 \times 10^{-11}$ & Xylene & $1.7 \times 10^{1}$ & $6.9 \times 10^{-4}$ \\
\hline $\mathrm{Pu}-238$ & $5.7 \times 10^{3}$ & $3.3 \times 10^{-6}$ & Cadmium & 5.4 & $2.4 \times 10^{-9}$ \\
\hline Pu-239 & $3.5 \times 10^{3}$ & $2.0 \times 10^{-6}$ & Mercury & $4.7 \times 10^{1}$ & $2.8 \times 10^{-8}$ \\
\hline $\mathrm{Pu}-240$ & $8.8 \times 10^{2}$ & $5.0 \times 10^{-7}$ & Lead & $2.0 \times 10^{4}$ & $9.6 \times 10^{-6}$ \\
\hline $\mathrm{Pu}-241$ & $2.6 \times 10^{4}$ & $1.5 \times 10^{-5}$ & & & \\
\hline Pu-242 & $9.1 \times 10^{-2}$ & $5.2 \times 10^{-11}$ & & & \\
\hline Am-241 & $7.6 \times 10^{3}$ & $4.4 \times 10^{-6}$ & & & \\
\hline $\mathrm{Cm}-244$ & $9.9 \times 10^{1}$ & $5.7 \times 10^{-8}$ & & & \\
\hline Cf-252 & $5.7 \times 10^{-3}$ & $3.3 \times 10^{-12}$ & & & \\
\hline \multicolumn{6}{|c|}{$\begin{array}{l}\text { Storage Site: LANL } \\
\text { Volume: } 1.1 \times 10^{3} \mathrm{~m}^{3} / \mathrm{yr}\end{array}$} \\
\hline Sr-90 & $3.1 \times 10^{1}$ & $1.7 \times 10^{-8}$ & Carbon tetrachloride & $4.2 \times 10^{1}$ & $1.6 \times 10^{-3}$ \\
\hline Y-90 & $3.1 \times 10^{1}$ & $1.7 \times 10^{-8}$ & Methyl alcohol & 5.4 & $3.2 \times 10^{-4}$ \\
\hline Cs-137 & $3.1 \times 10^{1}$ & $1.7 \times 10^{-8}$ & Butanol & 3.5 & $2.1 \times 10^{-4}$ \\
\hline Ba-137m & $2.0 \times 10^{1}$ & $1.1 \times 10^{-8}$ & Methyl chloroform & $8.0 \times 10^{1}$ & $3.1 \times 10^{-3}$ \\
\hline Pm-147 & $2.3 \times 10^{1}$ & $1.3 \times 10^{-8}$ & Methylene chloride & $2.7 \times 10^{2}$ & $1.0 \times 10^{-2}$ \\
\hline $\mathrm{U}-235$ & $5.2 \times 10^{-3}$ & $2.9 \times 10^{-12}$ & 1,1,2-trichloro-1,2,2- & $1.3 \times 10^{2}$ & $4.9 \times 10^{-3}$ \\
\hline U.238 & $2.9 \times 10^{-2}$ & $1.6 \times 10^{-11}$ & trifluoroethane & & \\
\hline $\mathrm{Pu}-238$ & $1.7 \times 10^{4}$ & $9.4 \times 10^{-6}$ & Ethyl benzene & 4.9 & $2.0 \times 10^{-4}$ \\
\hline Pu-239 & $6.5 \times 10^{3}$ & $3.6 \times 10^{-6}$ & Toluene & 4.9 & $2.0 \times 10^{-4}$ \\
\hline Pu-240 & $2.1 \times 10^{3}$ & $1.2 \times 10^{-6}$ & Xylene & $1.1 \times 10^{1}$ & $4.4 \times 10^{-4}$ \\
\hline $\mathrm{Pu}-241$ & $8.9 \times 10^{4}$ & $4.9 \times 10^{-5}$ & Cadmium & 3.5 & $1.5 \times 10^{-9}$ \\
\hline $\mathrm{Pu}-242$ & $2.6 \times 10^{-1}$ & $1.5 \times 10^{-10}$ & Mercury & $1.1 \times 10^{1}$ & $6.6 \times 10^{-9}$ \\
\hline $\mathrm{Am}-241$ & $1.9 \times 10^{4}$ & $1.1 \times 10^{-5}$ & Lead & $1.2 \times 10^{3}$ & $7.4 \times 10^{-7}$ \\
\hline
\end{tabular}


TABLE B.2 (Cont.)

\begin{tabular}{|c|c|c|c|c|c|}
\hline \multicolumn{3}{|c|}{ Radiological Profile } & \multicolumn{3}{|c|}{ Chemical Profile } \\
\hline Radionuclide & $\begin{array}{l}\text { Total } \\
(\mathrm{Ci} / \mathrm{yr})\end{array}$ & $\begin{array}{l}\text { Released } \\
(\mathrm{Ci} / \mathrm{yr})\end{array}$ & Contaminant & $\begin{array}{c}\text { Total } \\
(\mathrm{kg} / \mathrm{yr})\end{array}$ & $\begin{array}{c}\text { Released } \\
(\mathrm{kg} / \mathrm{yr})\end{array}$ \\
\hline \multicolumn{6}{|c|}{$\begin{array}{c}\text { Storage Site: LLNL } \\
\text { Volume: } 1.7 \times 10^{2} \mathrm{~m}^{3} / \mathrm{yr}\end{array}$} \\
\hline $\mathrm{Pu}-238$ & $1.4 \times 10^{1}$ & $7.1 \times 10^{-9}$ & Carbon tetrachloride & $1.2 \times 10^{3}$ & $4.8 \times 10^{-2}$ \\
\hline Pu-239 & $2.9 \times 10^{2}$ & $1.5 \times 10^{-7}$ & Methyl alcohol & $6.1 \times 10^{-1}$ & $1.3 \times 10^{-5}$ \\
\hline $\mathrm{Pu}-240$ & $8.4 \times 10^{1}$ & $4.3 \times 10^{-8}$ & Butanol & $3.9 \times 10^{-1}$ & $8.4 \times 10^{-6}$ \\
\hline $\mathrm{Pu}-241$ & $2.0 \times 10^{3}$ & $1.0 \times 10^{-6}$ & Methyl chloroform & $3.5 \times 10^{3}$ & $1.4 \times 10^{-1}$ \\
\hline $\mathrm{Pu}-242$ & $8.9 \times 10^{-3}$ & $4.5 \times 10^{-12}$ & Methylene chloride & $2.5 \times 10^{1}$ & $8.2 \times 10^{-4}$ \\
\hline \multirow[t]{7}{*}{ Am-241 } & $9.2 \times 10^{1}$ & $4.7 \times 10^{-8}$ & $\begin{array}{l}\text { 1,1,2-trichloro-1,2,2- } \\
\text { trifluoroethane }\end{array}$ & $1.2 \times 10^{3}$ & $4.8 \times 10^{-2}$ \\
\hline & & & Ethyl benzene & $5.6 \times 10^{-1}$ & $2.3 \times 10^{-5}$ \\
\hline & & & Toluene & $5.6 \times 10^{-1}$ & $2.3 \times 10^{-5}$ \\
\hline & & & Xylene & $5.6 \times 10^{-1}$ & $2.3 \times 10^{-5}$ \\
\hline & & & Cadmium & $3.9 \times 10^{-1}$ & $2.4 \times 10^{-10}$ \\
\hline & & & Mercury & 1.1 & $4.6 \times 10^{-10}$ \\
\hline & & & Lead & $1.2 \times 10^{4}$ & $5.0 \times 10^{-6}$ \\
\hline
\end{tabular}

Storage Site: Mound Volume: $1.6 \times 10^{1} \mathrm{~m}^{3} / \mathrm{vr}$

\begin{tabular}{|c|c|c|c|c|c|}
\hline $\mathrm{Pu}-238$ & $1.4 \times 10^{2}$ & $6.3 \times 10^{-8}$ & Carbon tetrachloride & $3.8 \times 10^{-1}$ & $1.6 \times 10^{-5}$ \\
\hline Pu-239 & $1.0 \times 10^{-1}$ & $4.6 \times 10^{-11}$ & Methyl alcohol & $2.2 \times 10^{-1}$ & $1.3 \times 10^{-5}$ \\
\hline \multirow[t]{9}{*}{ Pu-240 } & $7.2 \times 10^{-2}$ & $3.2 \times 10^{-11}$ & Butanol & $1.4 \times 10^{-1}$ & $8.4 \times 10^{-6}$ \\
\hline & & & Methyl chloroform & 1.2 & $5.2 \times 10^{-5}$ \\
\hline & & & Methylene chloride & 1.2 & $4.9 \times 10^{-5}$ \\
\hline & & & $\begin{array}{l}\text { 1,1,2-trichloro-1,2,2- } \\
\text { trifluoroethane }\end{array}$ & 1.2 & $5.2 \times 10^{-5}$ \\
\hline & & & Ethyl benzene & $1.9 \times 10^{-1}$ & $8.2 \times 10^{-6}$ \\
\hline & & & Toluene & $1.9 \times 10^{-1}$ & $8.2 \times 10^{-6}$ \\
\hline & & & Xylene & $4.3 \times 10^{-1}$ & $1.8 \times 10^{-5}$ \\
\hline & & & Cadmium & $1.4 \times 10^{-1}$ & $6.3 \times 10^{-11}$ \\
\hline & & & Lead & 1.2 & $5.6 \times 10^{-10}$ \\
\hline \multicolumn{6}{|c|}{$\begin{array}{l}\text { Storage Site: NTS } \\
\text { Volume: } 6.1 \times 10^{1} \mathrm{~m}^{3} / \mathrm{yr}\end{array}$} \\
\hline $\mathrm{Pu}-238$ & $3.2 \times 10^{-1}$ & $1.9 \times 10^{-10}$ & Carbon tetrachloride & 2.8 & $1.1 \times 10^{-4}$ \\
\hline Pu-239 & 7.9 & $4.8 \times 10^{-9}$ & Methyl chloroform & 4.1 & $1.7 \times 10^{-4}$ \\
\hline $\mathrm{Pu}-240$ & 1.8 & $1.1 \times 10^{-9}$ & Methylene chloride & $2.0 \times 10^{1}$ & $8.3 \times 10^{-4}$ \\
\hline $\mathrm{Pu}-241$ & $7.3 \times 10^{1}$ & $4.5 \times 10^{-8}$ & 1,1,2-trichloro-1,2,2- & 8.2 & $3.3 \times 10^{-4}$ \\
\hline \multirow[t]{3}{*}{$\mathrm{Pu}-242$} & $1.2 \times 10^{-4}$ & $7.4 \times 10^{-14}$ & trifluoroethane & & \\
\hline & & & Mercury & $9.2 \times 10^{-1}$ & $5.6 \times 10^{-10}$ \\
\hline & & & Lead & $1.0 \times 10^{2}$ & $6.1 \times 10^{-8}$ \\
\hline
\end{tabular}


TABLE B.2 (Cont.)

\begin{tabular}{|c|c|c|c|c|c|}
\hline \multicolumn{3}{|c|}{ Radiological Profile } & \multicolumn{3}{|c|}{ Chemical Profile } \\
\hline Radionuclide & $\begin{array}{c}\text { Total } \\
(\mathrm{Ci} / \mathrm{yr})\end{array}$ & $\begin{array}{c}\text { Released } \\
(\mathrm{Ci} / \mathrm{yr})\end{array}$ & Contaminant & $\begin{array}{c}\text { Total } \\
(\mathrm{kg} / \mathrm{yr})\end{array}$ & $\begin{array}{c}\text { Released } \\
(\mathrm{kg} / \mathrm{yr})\end{array}$ \\
\hline \multicolumn{6}{|c|}{$\begin{array}{l}\text { Storage Site: ORR } \\
\text { Volume: } 6.3 \mathrm{~m}^{3} / \mathrm{yr}\end{array}$} \\
\hline $\mathrm{Pu}-238$ & $4.4 \times 10^{-1}$ & $-{ }^{a}$ & Carbon tetrachloride & $5.7 \times 10^{-1}$ & - \\
\hline Pu-239 & 9.1 & - & Methyl alcohol & $9.9 \times 10^{-3}$ & - \\
\hline Pu-240 & 2.7 & - & Butanol & $6.4 \times 10^{-3}$ & - \\
\hline $\mathrm{Pu}-241$ & $6.4 \times 10^{1}$ & - & Methyl chloroform & $9.5 \times 10^{-1}$ & - \\
\hline $\mathrm{Pu}-242$ & $2.8 \times 10^{-4}$ & - & Methylene chloride & $4.5 \times 10^{-1}$ & - \\
\hline \multirow[t]{6}{*}{ Am-241 } & 2.9 & - & $\begin{array}{l}\text { 1,1,2-trichloro-1,2,2- } \\
\text { trifluoroethane }\end{array}$ & $8.7 \times 10^{-1}$ & - \\
\hline & & & Ethyl benzene & $1.7 \times 10^{-2}$ & - \\
\hline & & & Toluene & $1.7 \times 10^{-2}$ & - \\
\hline & & & Xylene & $2.8 \times 10^{-2}$ & - \\
\hline & & & Cadmium & $1.2 \times 10^{-2}$ & - \\
\hline & & & Lead & $9.5 \times 10^{-1}$ & - \\
\hline \multicolumn{6}{|c|}{$\begin{array}{l}\text { Storage Site: RFETS } \\
\text { Volume: } 6.0 \times 10^{2} \mathrm{~m}^{3} / \mathrm{yr}\end{array}$} \\
\hline U-235 & $9.6 \times 10^{-5}$ & $4.2 \times 10^{-14}$ & Carbon tetrachloride & 9.2 & $3.1 \times 10^{-4}$ \\
\hline $\mathrm{Pu}-238$ & $3.7 \times 10^{1}$ & $1.6 \times 10^{-8}$ & Methyl alcohol & 2.2 & $1.2 \times 10^{-4}$ \\
\hline $\mathrm{Pu}-239$ & $1.0 \times 10^{3}$ & $4.5 \times 10^{-7}$ & Butanol & 1.4 & $7.8 \times 10^{-5}$ \\
\hline $\mathrm{Pu}-240$ & $2.5 \times 10^{2}$ & $1.1 \times 10^{-7}$ & Methyl chloroform & $2.9 \times 10^{1}$ & $9.8 \times 10^{-4}$ \\
\hline Pu-241 & $6.6 \times 10^{3}$ & $2.9 \times 10^{-6}$ & Methylene chloride & $1.2 \times 10^{2}$ & $3.9 \times 10^{-3}$ \\
\hline $\mathrm{Pu}-242$ & $7.2 \times 10^{-3}$ & $3.1 \times 10^{-12}$ & 1,1,2-trichloro-1,2,2- & $6.1 \times 10^{1}$ & $2.0 \times 10^{-3}$ \\
\hline \multirow[t]{7}{*}{ Am-241 } & $1.9 \times 10^{3}$ & $4.7 \times 10^{-7}$ & trifluoroethane & & \\
\hline & & & Ethyl benzene & 2.0 & $7.3 \times 10^{-5}$ \\
\hline & & & Toluene & 2.0 & $7.3 \times 10^{-5}$ \\
\hline & & & Xylene & 4.4 & $1.6 \times 10^{-4}$ \\
\hline & & & Cadmium & 1.4 & $6.4 \times 10^{-10}$ \\
\hline & & & Mercury & 5.4 & $2.3 \times 10^{-9}$ \\
\hline & & & Lead & $5.9 \times 10^{4}$ & $2.5 \times 10^{-5}$ \\
\hline
\end{tabular}


TABLE B.2 (Cont.)

\begin{tabular}{|c|c|c|c|c|c|}
\hline \multicolumn{3}{|c|}{ Radiological Profile } & \multicolumn{3}{|c|}{ Chemical Profile } \\
\hline Radionuclide & $\begin{array}{l}\text { Total } \\
(\mathrm{Ci} / \mathrm{yr}) \\
\end{array}$ & $\begin{array}{c}\text { Released } \\
(\mathrm{Ci} / \mathrm{yr})\end{array}$ & Contaminant & $\begin{array}{c}\text { Total } \\
(\mathrm{kg} / \mathrm{yr})\end{array}$ & $\begin{array}{c}\text { Released } \\
(\mathrm{kg} / \mathrm{vr})\end{array}$ \\
\hline \multicolumn{6}{|c|}{$\begin{array}{l}\text { Storage Site: SRS } \\
\text { Volume: } 3.7 \times 10^{2} \mathrm{~m}^{3} / \mathrm{yr}\end{array}$} \\
\hline$C-14$ & $6.28 \times 10^{-4}$ & & Carbon tetrachloride & 6.15 & $2.46 \times 10^{-4}$ \\
\hline Co-60 & $1.15 \times 10^{-1}$ & $4.90 \times 10^{-11}$ & Methyl alcohol & $7.22 \times 10^{-5}$ & $4.33 \times 10^{-9}$ \\
\hline $\mathrm{Ni}-59$ & $4.05 \times 10^{-4}$ & $1.72 \times 10^{-13}$ & Butanol & $4.66 \times 10^{-5}$ & $2.79 \times 10^{-9}$ \\
\hline $\mathrm{Ni}-63$ & $4.94 \times 10^{-2}$ & $2.10 \times 10^{-11}$ & Methyl chloroform & 9.84 & $3.99 \times 10^{-4}$ \\
\hline $\mathrm{Sr}-90$ & 2.53 & $9.62 \times 10^{-10}$ & Methylene chloride & $4.21 \times 10^{1}$ & $1.65 \times 10^{-3}$ \\
\hline Cs- 137 & 2.70 & $1.04 \times 10^{-9}$ & 1,1,2-trichloro-1,2,2- & $1.74 \times 10^{1}$ & $6.88 \times 10^{-4}$ \\
\hline Pm-147 & $1.88 \times 10^{-5}$ & & trifluoroethane & & \\
\hline Eu-155 & $1.71 \times 10^{1}$ & $7.28 \times 10^{-9}$ & Ethyl benzene & $6.56 \times 10^{-5}$ & $2.71 \times 10^{-9}$ \\
\hline $\mathrm{Ra}-228$ & $3.30 \times 10^{-3}$ & $1.39 \times 10^{-12}$ & Toluene & $6.56 \times 10^{-5}$ & $2.71 \times 10^{-9}$ \\
\hline Th-229 & $5.13 \times 10^{-5}$ & & Xylene & $1.44 \times 10^{-4}$ & $5.96 \times 10^{-9}$ \\
\hline Th-230 & $7.60 \times 10^{-4}$ & $3.23 \times 10^{-13}$ & Cadmium & $4.66 \times 10^{-5}$ & $2.04 \times 10^{-14}$ \\
\hline Th-232 & $6.94 \times 10^{-3}$ & $2.94 \times 10^{-12}$ & Mercury & 1.91 & $8.13 \times 10^{-10}$ \\
\hline U-232 & $2.90 \times 10^{-2}$ & $1.23 \times 10^{-11}$ & Lead & $2.10 \times 10^{2}$ & $8.94 \times 10^{-8}$ \\
\hline U-233 & 1.25 & $5.17 \times 10^{-10}$ & & & \\
\hline U-234 & 8.31 & $3.53 \times 10^{-9}$ & & & \\
\hline U-235 & $2.56 \times 10^{-3}$ & $8.05 \times 10^{-13}$ & & & \\
\hline U-236 & $1.55 \times 10^{-2}$ & $6.59 \times 10^{-12}$ & & & \\
\hline U-238 & $4.15 \times 10^{-3}$ & $7.86 \times 10^{-13}$ & & & \\
\hline Np-237 & 2.79 & $1.18 \times 10^{-9}$ & & & \\
\hline $\mathrm{Pu}-238$ & $1.58 \times 10^{5}$ & $6.71 \times 10^{-5}$ & & & \\
\hline Pu-239 & $3.02 \times 10^{3}$ & $1.23 \times 10^{-6}$ & & & \\
\hline $\mathrm{Pu}-240$ & $7.45 \times 10^{2}$ & $3.16 \times 10^{-7}$ & & & \\
\hline Pu-241 & $2.01 \times 10^{4}$ & $8.54 \times 10^{-6}$ & & & \\
\hline Am-241 & $1.22 \times 10^{3}$ & $5.18 \times 10^{-7}$ & & & \\
\hline $\mathrm{Cm}-244$ & $2.42 \times 10^{2}$ & $1.03 \times 10^{-7}$ & & & \\
\hline $\mathrm{Cm}-245$ & $6.59 \times 10^{-3}$ & & & & \\
\hline Cf-252 & $1.38 \times 10^{-2}$ & & & & \\
\hline
\end{tabular}

a No release from treated waste that is packaged for WIPP-WAC compliance and received for interim storage only. 
TABLE B.3 Projected Waste Loads and Release Profiles by Site in CH-TRUW Regionalized/Intermediate Treatment/Five Sites Alternative

\begin{tabular}{|c|c|c|c|c|c|}
\hline \multicolumn{3}{|c|}{ Radiological Profile } & \multicolumn{3}{|c|}{ Chemical Profile } \\
\hline Radionuclide & $\begin{array}{c}\text { Total } \\
\text { (Ci/yr) } \\
\end{array}$ & $\begin{array}{l}\text { Released } \\
(\mathrm{Ci} / \mathrm{yr})\end{array}$ & Contaminant & $\begin{array}{c}\text { Total } \\
(\mathrm{kg} / \mathrm{yr})\end{array}$ & $\begin{array}{c}\text { Released } \\
(\mathrm{kg} / \mathrm{yr})\end{array}$ \\
\hline \multicolumn{6}{|c|}{$\begin{array}{l}\text { Treatment Site: Hanford } \\
\text { Volume: } 8.6 \times 10^{2} \mathrm{~m}^{3} / \mathrm{yr}\end{array}$} \\
\hline C-14 & $4.59 \times 10^{-1}$ & $3.52 \times 10^{-10}$ & Carbon tetrachloride & $1.92 \times 10^{1}$ & $9.44 \times 10^{-4}$ \\
\hline Sr -90 & $1.98 \times 10^{2}$ & $1.52 \times 10^{-7}$ & Methyl alcohol & $6.17 \times 10^{-1}$ & $2.55 \times 10^{-5}$ \\
\hline Cs- 137 & $1.96 \times 10^{2}$ & $1.50 \times 10^{-7}$ & Butanol & $3.98 \times 10^{-1}$ & $1.64 \times 10^{-5}$ \\
\hline Pm-147 & $1.37 \times 10^{-2}$ & $1.05 \times 10^{-11}$ & Methyl chloroform & $3.08 \times 10^{1}$ & $1.50 \times 10^{-3}$ \\
\hline $\mathrm{Ra}-228$ & $1.60 \times 10^{-2}$ & $1.23 \times 10^{-11}$ & Methylene chloride & $1.29 \times 10^{2}$ & $6.40 \times 10^{-3}$ \\
\hline Th-229 & $3.75 \times 10^{-2}$ & $2.88 \times 10^{-11}$ & 1,1,2-trichloro-1,2,2- & $5.57 \times 10^{1}$ & $2.74 \times 10^{-3}$ \\
\hline Th-232 & $1.92 \times 10^{-2}$ & $1.48 \times 10^{-11}$ & trifluoroethane & & \\
\hline U.233 & $2.29 \times 10^{1}$ & $1.76 \times 10^{-8}$ & Ethyl benzene & $5.61 \times 10^{-1}$ & $2.30 \times 10^{-5}$ \\
\hline U-234 & $1.54 \times 10^{1}$ & $1.18 \times 10^{-8}$ & Toluene & $5.61 \times 10^{-1}$ & $2.30 \times 10^{-5}$ \\
\hline $\mathrm{U}-235$ & $4.91 \times 10^{-1}$ & $3.77 \times 10^{-10}$ & Xylene & 1.23 & $5.07 \times 10^{-5}$ \\
\hline$U-236$ & $3.99 \times 10^{-6}$ & $2.99 \times 10^{-15}$ & Cadmium & $3.98 \times 10^{-1}$ & $2.46 \times 10^{-10}$ \\
\hline$U-238$ & 1.70 & $1.30 \times 10^{-9}$ & Mercury & 5.68 & $4.47 \times 10^{-9}$ \\
\hline Pu-238 & $2.31 \times 10^{4}$ & $1.78 \times 10^{-5}$ & Lead & $6.90 \times 10^{2}$ & $5.41 \times 10^{-7}$ \\
\hline Pu-239 & $7.62 \times 10^{3}$ & $5.85 \times 10^{-6}$ & & & \\
\hline Pu-240 & $1.80 \times 10^{3}$ & $1.38 \times 10^{-6}$ & & & \\
\hline $\mathrm{Pu}-241$ & $1.17 \times 10^{4}$ & $8.95 \times 10^{-6}$ & & & \\
\hline Am-241 & $1.43 \times 10^{3}$ & $1.10 \times 10^{-6}$ & & & \\
\hline Am- 243 & $1.28 \times 10^{-2}$ & $9.62 \times 10^{-12}$ & & & \\
\hline $\mathrm{Cm}-244$ & $5.38 \times 10^{1}$ & $4.07 \times 10^{-8}$ & & & \\
\hline $\mathrm{Cm}-245$ & 4.81 & $3.69 \times 10^{-9}$ & & & \\
\hline Cf-252 & $1.01 \times 10^{1}$ & $7.76 \times 10^{-9}$ & & & \\
\hline \multicolumn{6}{|c|}{$\begin{array}{c}\text { Treatment Site: INEL } \\
\text { Volume: } 3.9 \times 10^{3} \mathrm{~m}^{3} / \mathrm{yr}\end{array}$} \\
\hline Sr-90 & $5.3 \times 10^{1}$ & $3.9 \times 10^{-8}$ & Carbon tetrachloride & $6.3 \times 10^{3}$ & $2.7 \times 10^{-1}$ \\
\hline Ru-106 & $6.9 \times 10^{-2}$ & $4.9 \times 10^{-11}$ & Methyl alcohol & 8.4 & $5.1 \times 10^{-4}$ \\
\hline Cs-137 & $6.9 \times 10^{1}$ & $4.9 \times 10^{-8}$ & Butanol & 5.4 & $3.3 \times 10^{-4}$ \\
\hline Ce-144 & $4.9 \times 10^{-1}$ & $3.6 \times 10^{-10}$ & Methyl chloroform & $1.9 \times 10^{4}$ & $7.9 \times 10^{-1}$ \\
\hline Pm-147 & $2.2 \times 10^{2}$ & $1.6 \times 10^{-7}$ & Methylene chloride & $1.1 \times 10^{3}$ & $6.4 \times 10^{-2}$ \\
\hline Th-232 & $2.9 \times 10^{-2}$ & $2.1 \times 10^{-11}$ & 1,1,2-trichloro-1,2,2- & $6.6 \times 10^{3}$ & $2.8 \times 10^{-1}$ \\
\hline $\mathrm{U}-233$ & $7.9 \times 10^{1}$ & $5.8 \times 10^{-8}$ & trifluoroethane & & \\
\hline $\mathrm{U}-235$ & $1.4 \times 10^{-2}$ & $1.1 \times 10^{-11}$ & Ethyl benzene & 7.7 & $3.2 \times 10^{-4}$ \\
\hline $\mathrm{U}-238$ & $1.2 \times 10^{-2}$ & $8.9 \times 10^{-12}$ & Toluene & 7.7 & $3.2 \times 10^{-4}$ \\
\hline Np-237 & $5.7 \times 10^{-2}$ & $4.2 \times 10^{-11}$ & Xylene & $1.7 \times 10^{1}$ & $6.9 \times 10^{-4}$ \\
\hline $\mathrm{Pu}-238$ & $5.7 \times 10^{3}$ & $4.2 \times 10^{-6}$ & Cadmium & 5.4 & $2.4 \times 10^{-9}$ \\
\hline Pu-239 & $3.6 \times 10^{3}$ & $2.6 \times 10^{-6}$ & Mercury & $4.8 \times 10^{1}$ & $3.8 \times 10^{-8}$ \\
\hline $\mathrm{Pu}-240$ & $8.8 \times 10^{2}$ & $6.4 \times 10^{-7}$ & Lead & $2.0 \times 10^{4}$ & $1.6 \times 10^{-5}$ \\
\hline Pu-241 & $2.6 \times 10^{4}$ & $1.9 \times 10^{-5}$ & & & \\
\hline $\mathrm{Pu}-242$ & $9.2 \times 10^{-2}$ & $6.7 \times 10^{-11}$ & & & \\
\hline Am-241 & $7.6 \times 10^{3}$ & $5.5 \times 10^{-6}$ & & & \\
\hline $\mathrm{Cm}-244$ & $9.9 \times 10^{1}$ & $7.2 \times 10^{-8}$ & & & \\
\hline Cf-252 & $5.7 \times 10^{-3}$ & $4.2 \times 10^{-12}$ & & & \\
\hline
\end{tabular}


TABLE B.3 (Cont.)

\begin{tabular}{|c|c|c|c|c|c|}
\hline \multicolumn{3}{|c|}{ Radiological Profile } & \multicolumn{3}{|c|}{ Chemical Profile } \\
\hline Radionuclide & $\begin{array}{c}\text { Total } \\
(\mathrm{Ci} / \mathrm{yr}) \\
\end{array}$ & $\begin{array}{c}\text { Released } \\
(\mathrm{Ci} / \mathrm{yr}) \\
\end{array}$ & Contaminant & $\begin{array}{r}\text { Total } \\
(\mathrm{kg} / \mathrm{yr}) \\
\end{array}$ & $\begin{array}{c}\text { Released } \\
(\mathrm{kg} / \mathrm{yr})\end{array}$ \\
\hline \multicolumn{6}{|c|}{$\begin{array}{l}\text { Treatment Site: LANL } \\
\text { Volume: } 1.1 \times 10^{3} \mathrm{~m}^{3} / \mathrm{yr}\end{array}$} \\
\hline Sr-90 & $3.1 \times 10^{1}$ & $2.1 \times 10^{-8}$ & Carbon tetrachloride & $4.2 \times 10^{1}$ & $2.2 \times 10^{-3}$ \\
\hline$Y-90$ & $3.1 \times 10^{1}$ & $2.1 \times 10^{-8}$ & Methyl alcohol & 5.4 & $3.2 \times 10^{-4}$ \\
\hline Cs-137 & $3.1 \times 10^{1}$ & $2.1 \times 10^{-8}$ & Butanol & 3.5 & $2.1 \times 10^{-4}$ \\
\hline $\mathrm{Ba}-137 \mathrm{~m}$ & $2.0 \times 10^{1}$ & $1.4 \times 10^{-8}$ & Methyl chloroform & $8.0 \times 10^{1}$ & $4.0 \times 10^{-3}$ \\
\hline Pm-147 & $2.3 \times 10^{1}$ & $1.6 \times 10^{-8}$ & Methylene chloride & $2.7 \times 10^{2}$ & $1.5 \times 10^{-2}$ \\
\hline $\mathrm{U}-235$ & $5.2 \times 10^{-3}$ & $3.5 \times 10^{-12}$ & 1,1,2-trichloro-1,2,2- & $1.3 \times 10^{2}$ & $6.7 \times 10^{-3}$ \\
\hline U-238 & $2.9 \times 10^{-2}$ & $1.9 \times 10^{-11}$ & trifluoroethane & & \\
\hline $\mathrm{Pu}-238$ & $1.7 \times 10^{4}$ & $1.1 \times 10^{-5}$ & Ethyl benzene & 4.9 & $2.0 \times 10^{-4}$ \\
\hline $\mathrm{Pu}-239$ & $6.5 \times 10^{3}$ & $4.4 \times 10^{-6}$ & Toluene & 4.9 & $2.0 \times 10^{-4}$ \\
\hline $\mathrm{Pu}-240$ & $2.1 \times 10^{3}$ & $1.4 \times 10^{-6}$ & Xylene & $1.1 \times 10^{1}$ & $4.4 \times 10^{-4}$ \\
\hline Pu-241 & $8.9 \times 10^{4}$ & $6.1 \times 10^{-5}$ & Cadmium & 3.5 & $1.5 \times 10^{-9}$ \\
\hline $\mathrm{Pu}-242$ & $2.6 \times 10^{-1}$ & $1.8 \times 10^{-10}$ & Mercury & $1.1 \times 10^{1}$ & $8.6 \times 10^{-9}$ \\
\hline Am-241 & $1.9 \times 10^{4}$ & $1.3 \times 10^{-5}$ & Lead & $1.2 \times 10^{3}$ & $9.5 \times 10^{-7}$ \\
\hline \multicolumn{6}{|c|}{$\begin{array}{l}\text { Treatment Site: RFETS } \\
\text { Volume: } 6.0 \times 10^{2} \mathrm{~m}^{3} / \mathrm{yr}\end{array}$} \\
\hline $\mathrm{U}-235$ & $9.6 \times 10^{-5}$ & $6.7 \times 10^{-4}$ & Carbon tetrachloride & 9.2 & $4.1 \times 10^{-4}$ \\
\hline $\mathrm{Pu}-238$ & $3.7 \times 10^{1}$ & $2.6 \times 10^{-8}$ & Methyl alcohol & 2.2 & $1.2 \times 10^{-4}$ \\
\hline Pu-239 & $1.0 \times 10^{3}$ & $7.1 \times 10^{-7}$ & Butanol & 1.4 & $7.8 \times 10^{-5}$ \\
\hline Pu-240 & $2.5 \times 10^{2}$ & $1.7 \times 10^{-7}$ & Methyl chloroform & $2.9 \times 10^{1}$ & $1.3 \times 10^{-3}$ \\
\hline $\mathrm{Pu}-241$ & $6.6 \times 10^{3}$ & $4.6 \times 10^{-6}$ & Methylene chloride & $1.2 \times 10^{2}$ & $5.9 \times 10^{-3}$ \\
\hline $\mathrm{Pu}-242$ & $7.2 \times 10^{-3}$ & $5.0 \times 10^{-2}$ & 1,1,2-trichloro-1,2,2- & $6.1 \times 10^{1}$ & $2.9 \times 10^{-3}$ \\
\hline \multirow[t]{7}{*}{ Am-241 } & $1.1 \times 10^{3}$ & $7.6 \times 10^{-7}$ & trifluoroethane & & \\
\hline & & & Ethyl benzene & 2.0 & $7.3 \times 10^{-5}$ \\
\hline & & & Toluene & 2.0 & $7.3 \times 10^{-5}$ \\
\hline & & & Xylene & 4.4 & $1.6 \times 10^{-4}$ \\
\hline & & & Cadmium & 1.4 & $6.4 \times 10^{-10}$ \\
\hline & & & Mercury & 5.4 & $4.2 \times 10^{-9}$ \\
\hline & & & Lead & $5.9 \times 10^{4}$ & $4.6 \times 10^{-5}$ \\
\hline
\end{tabular}


TABLE B.3 (Cont.)

Radiological Profile

Chemical Profile

\begin{tabular}{|c|c|c|c|c|c|}
\hline Radionuclide & $\begin{array}{c}\text { Total } \\
(\mathrm{Ci} / \mathrm{yr})\end{array}$ & $\begin{array}{c}\text { Released } \\
(\mathrm{Ci} / \mathrm{yr})\end{array}$ & Contaminant & $\begin{array}{c}\text { Total } \\
(\mathrm{kg} / \mathrm{yr})\end{array}$ & $\begin{array}{c}\text { Released } \\
(\mathrm{kg} / \mathrm{yr})\end{array}$ \\
\hline \multicolumn{6}{|c|}{$\begin{array}{c}\text { Treatment Site: SRS } \\
\text { Volume: } 5.7 \times 10^{2} \mathrm{~m}^{3} / \mathrm{yr}\end{array}$} \\
\hline C-14 & $1.04 \times 10^{-3}$ & $7.66 \times 10^{-13}$ & Carbon tetrachloride & 7.51 & $4.00 \times 10^{-4}$ \\
\hline Co-60 & $1.15 \times 10^{-1}$ & $9.06 \times 10^{-11}$ & Methyl alcohol & $5.45 \times 10^{-3}$ & $2.11 \times 10^{-7}$ \\
\hline $\mathrm{Ni}-59$ & $4.05 \times 10^{-4}$ & $3.18 \times 10^{-13}$ & Butanol & $3.52 \times 10^{-3}$ & $1.36 \times 10^{-7}$ \\
\hline $\mathrm{Ni}-63$ & $4.94 \times 10^{-2}$ & $3.88 \times 10^{-11}$ & Methyl chloroform & $1.25 \times 10^{1}$ & $6.45 \times 10^{-4}$ \\
\hline Sr-90 & $1.69 \times 10^{2}$ & $1.33 \times 10^{-7}$ & Methylene chloride & $4.88 \times 10^{1}$ & $2.71 \times 10^{-3}$ \\
\hline Tc-99 & 2.01 & $1.58 \times 10^{-9}$ & 1,1,2-trichloro-1,2,2- & $2.06 \times 10^{1}$ & $1.13 \times 10^{-3}$ \\
\hline Cs-137 & $2.65 \times 10^{2}$ & $2.08 \times 10^{-7}$ & trifluoroethane & & \\
\hline Pm-147 & $3.09 \times 10^{-5}$ & $2.29 \times 10^{-14}$ & Ethyl benzene & $4.96 \times 10^{-3}$ & $1.14 \times 10^{-7}$ \\
\hline Eu-155 & $1.71 \times 10^{1}$ & $1.35 \times 10^{-8}$ & Toluene & $4.96 \times 10^{-3}$ & $1.14 \times 10^{-7}$ \\
\hline $\mathrm{Pb}-210$ & $1.43 \times 10^{-1}$ & $1.12 \times 10^{-10}$ & Xylene & $1.01 \times 10^{-2}$ & $2.25 \times 10^{-7}$ \\
\hline $\mathrm{Ra}-226$ & $7.38 \times 10^{-1}$ & $5.79 \times 10^{-10}$ & Cadmium & $3.52 \times 10^{-3}$ & $1.63 \times 10^{-12}$ \\
\hline $\mathrm{Ra}-228$ & $3.31 \times 10^{-3}$ & $2.60 \times 10^{-12}$ & Mercury & 2.21 & $1.74 \times 10^{-9}$ \\
\hline Th-229 & $2.34 \times 10^{-2}$ & $1.84 \times 10^{-11}$ & Lead & $2.53 \times 10^{2}$ & $1.99 \times 10^{-7}$ \\
\hline Th-230 & $7.60 \times 10^{-4}$ & $5.98 \times 10^{-13}$ & & & \\
\hline Th-232 & $6.96 \times 10^{-3}$ & $5.47 \times 10^{-12}$ & & & \\
\hline $\mathrm{Pa}-231$ & $3.55 \times 10^{-2}$ & $2.78 \times 10^{-11}$ & & & \\
\hline U-232 & $6.17 \times 10^{-2}$ & $4.85 \times 10^{-11}$ & & & \\
\hline U-233 & $2.12 \times 10^{1}$ & $1.67 \times 10^{-8}$ & & & \\
\hline U-234 & $1.01 \times 10^{1}$ & $7.93 \times 10^{-9}$ & & & \\
\hline $\mathrm{U}-235$ & $3.07 \times 10^{-3}$ & $2.36 \times 10^{-12}$ & & & \\
\hline $\mathrm{U}-236$ & $1.55 \times 10^{-2}$ & $1.22 \times 10^{-11}$ & & & \\
\hline U-238 & $5.71 \times 10^{-3}$ & $4.30 \times 10^{-12}$ & & & \\
\hline Np-237 & 8.38 & $5.14 \times 10^{-9}$ & & & \\
\hline $\mathrm{Pu}-238$ & $1.58 \times 10^{5}$ & $1.24 \times 10^{-4}$ & & & \\
\hline Pu-239 & $3.35 \times 10^{3}$ & $2.63 \times 10^{-6}$ & & & \\
\hline $\mathrm{Pu}-240$ & $8.54 \times 10^{2}$ & $6.71 \times 10^{-7}$ & & & \\
\hline $\mathrm{Pu}-241$ & $2.55 \times 10^{4}$ & $2.01 \times 10^{-5}$ & & & \\
\hline Pu-242 & $7.59 \times 10^{-5}$ & $4.55 \times 10^{-14}$ & & & \\
\hline Am-241 & $1.41 \times 10^{3}$ & $1.11 \times 10^{-6}$ & & & \\
\hline Am- 243 & 1.43 & $1.11 \times 10^{-9}$ & & & \\
\hline $\mathrm{Cm}-244$ & $3.61 \times 10^{2}$ & $2.84 \times 10^{-7}$ & & & \\
\hline $\mathrm{Cm}-245$ & $1.09 \times 10^{-2}$ & $8.04 \times 10^{-12}$ & & & \\
\hline Cf- 252 & $2.28 \times 10^{-2}$ & $1.69 \times 10^{-11}$ & & & \\
\hline
\end{tabular}


TABLE B.4 Projected Waste Loads and Release Profiles by Site in CH-TRUW Regionalized/Treatment to LDRs/Five Sites Alternative

\begin{tabular}{|c|c|c|c|c|c|}
\hline \multicolumn{3}{|c|}{ Radiological Profile } & \multicolumn{3}{|c|}{ Chemical Profile } \\
\hline Radionuclide & $\begin{array}{c}\text { Total } \\
\text { (Ci/yr) }\end{array}$ & $\begin{array}{c}\text { Released } \\
(\mathrm{Ci} / \mathrm{yr})\end{array}$ & Contaminant & $\begin{array}{c}\text { Total } \\
(\mathrm{kg} / \mathrm{yr})\end{array}$ & $\begin{array}{c}\text { Released } \\
(\mathrm{kg} / \mathrm{yr})\end{array}$ \\
\hline \multicolumn{6}{|c|}{$\begin{array}{l}\text { Treatment Site: Hanford } \\
\text { Volume: } 8.6 \times 10^{2} \mathrm{~m}^{3} / \mathrm{yr}\end{array}$} \\
\hline$C-14$ & $4.59 \times 10^{-1}$ & $8.68 \times 10^{-2}$ & Carbon tetrachloride & $1.92 \times 10^{1}$ & $8.79 \times 10^{-4}$ \\
\hline Sr -90 & $1.98 \times 10^{2}$ & $8.26 \times 10^{-4}$ & Methyl alcohol & $6.17 \times 10^{-1}$ & $1.43 \times 10^{-5}$ \\
\hline Cs-137 & $1.96 \times 10^{2}$ & $8.15 \times 10^{-4}$ & Butanol & $3.98 \times 10^{-1}$ & $9.25 \times 10^{-6}$ \\
\hline Pm-147 & $1.37 \times 10^{-2}$ & $5.70 \times 10^{-8}$ & Methyl chloroform & $3.08 \times 10^{1}$ & $1.37 \times 10^{-3}$ \\
\hline Ra-228 & $1.60 \times 10^{-2}$ & $6.68 \times 10^{-8}$ & Methylene chloride & $1.29 \times 10^{2}$ & $6.21 \times 10^{-3}$ \\
\hline Th-229 & $3.75 \times 10^{-2}$ & $1.56 \times 10^{-7}$ & 1,1,2-trichloro-1,2,2- & $5.57 \times 10^{1}$ & $2.59 \times 10^{-3}$ \\
\hline Th-232 & $1.92 \times 10^{-2}$ & $8.01 \times 10^{-8}$ & trifluoroethane & & \\
\hline$U-233$ & $2.29 \times 10^{1}$ & $9.55 \times 10^{-5}$ & Ethyl benzene & $5.61 \times 10^{-1}$ & $1.30 \times 10^{-5}$ \\
\hline $\mathrm{U}-234$ & $1.54 \times 10^{1}$ & $6.42 \times 10^{-5}$ & Toluene & $5.61 \times 10^{-1}$ & $1.30 \times 10^{-5}$ \\
\hline U-235 & $4.91 \times 10^{-1}$ & $2.05 \times 10^{-6}$ & Xylene & 1.23 & $2.87 \times 10^{-5}$ \\
\hline U-236 & $3.99 \times 10^{-6}$ & $8.43 \times 10^{-11}$ & Cadmium & $3.98 \times 10^{-1}$ & $5.55 \times 10^{-7}$ \\
\hline $\mathrm{U}-238$ & 1.70 & $7.33 \times 10^{-6}$ & Mercury & 5.68 & $4.50 \times 10^{-9}$ \\
\hline $\mathrm{Pu}-238$ & $2.31 \times 10^{4}$ & $9.69 \times 10^{-2}$ & Lead & $6.90 \times 10^{2}$ & $1.32 \times 10^{-4}$ \\
\hline $\mathrm{Pu}-239$ & $7.62 \times 10^{3}$ & $3.32 \times 10^{-2}$ & & & \\
\hline $\mathrm{Pu}-240$ & $1.80 \times 10^{3}$ & $8.05 \times 10^{-3}$ & & & \\
\hline Pu-241 & $1.17 \times 10^{4}$ & $6.31 \times 10^{-2}$ & & & \\
\hline Am-241 & $1.43 \times 10^{3}$ & $7.24 \times 10^{-3}$ & & & \\
\hline Am-243 & $1.28 \times 10^{-2}$ & $2.71 \times 10^{-7}$ & & & \\
\hline $\mathrm{Cm}-244$ & $5.38 \times 10^{1}$ & $8.04 \times 10^{-4}$ & & & \\
\hline $\mathrm{Cm}-245$ & 4.81 & $2.00 \times 10^{-5}$ & & & \\
\hline Cf-252 & $1.01 \times 10^{1}$ & $4.21 \times 10^{-5}$ & & & \\
\hline \multicolumn{6}{|c|}{$\begin{array}{c}\text { Treatment Site: INEL } \\
\text { Volume: } 3.9 \times 10^{3} \mathrm{~m}^{3} / \mathrm{yr}\end{array}$} \\
\hline Sr-90 & $5.3 \times 10^{1}$ & $1.9 \times 10^{-4}$ & Carbon tetrachloride & $6.3 \times 10^{3}$ & $1.9 \times 10^{-1}$ \\
\hline Ru-106 & $6.9 \times 10^{-2}$ & $2.6 \times 10^{-7}$ & Methyl alcohol & 8.4 & $2.5 \times 10^{-4}$ \\
\hline Cs-137 & $6.9 \times 10^{1}$ & $2.6 \times 10^{-4}$ & Butanol & 5.4 & $1.6 \times 10^{-4}$ \\
\hline $\mathrm{Ce}-144$ & $4.9 \times 10^{-1}$ & $1.9 \times 10^{-6}$ & Methyl chloroform & $1.9 \times 10^{4}$ & $5.7 \times 10^{-1}$ \\
\hline Pm-147 & $2.2 \times 10^{2}$ & $8.3 \times 10^{-4}$ & Methylene chloride & $1.1 \times 10^{3}$ & $6.3 \times 10^{-2}$ \\
\hline Th-232 & $2.9 \times 10^{-2}$ & $1.1 \times 10^{-7}$ & 1,1,2-trichloro-1,2,2- & $6.6 \times 10^{3}$ & $2.1 \times 10^{-1}$ \\
\hline$U-233$ & $7.9 \times 10^{1}$ & $2.9 \times 10^{-4}$ & trifluoroethane & & \\
\hline$U-235$ & $1.4 \times 10^{-2}$ & $5.4 \times 10^{-8}$ & Ethyl benzene & 7.7 & $2.3 \times 10^{-4}$ \\
\hline U-238 & $1.2 \times 10^{-2}$ & $4.6 \times 10^{-8}$ & Toluene & 7.7 & $2.3 \times 10^{-4}$ \\
\hline Np-237 & $5.7 \times 10^{-2}$ & $2.1 \times 10^{-7}$ & Xylene & $1.7 \times 10^{1}$ & $5.2 \times 10^{-4}$ \\
\hline Pu-238 & $5.7 \times 10^{3}$ & $2.1 \times 10^{-2}$ & Cadmium & 5.4 & $6.3 \times 10^{-6}$ \\
\hline Pu-239 & $3.6 \times 10^{3}$ & $1.3 \times 10^{-2}$ & Mercury & $4.8 \times 10^{1}$ & $3.8 \times 10^{-8}$ \\
\hline $\mathrm{Pu}-240$ & $8.8 \times 10^{2}$ & $3.3 \times 10^{-3}$ & Lead & $2.0 \times 10^{4}$ & $1.0 \times 10^{-3}$ \\
\hline Pu-241 & $2.6 \times 10^{4}$ & $9.5 \times 10^{-2}$ & & & \\
\hline $\mathrm{Pu}-242$ & $9.2 \times 10^{-2}$ & $3.4 \times 10^{-7}$ & & & \\
\hline Am-241 & $7.6 \times 10^{3}$ & $2.8 \times 10^{-2}$ & & & \\
\hline $\mathrm{Cm}-244$ & $9.9 \times 10^{1}$ & $3.7 \times 10^{-4}$ & & & \\
\hline Cf- -252 & $5.7 \times 10^{-3}$ & $2.1 \times 10^{-8}$ & & & \\
\hline
\end{tabular}


TABLE B.4 (Cont.)

\begin{tabular}{|c|c|c|c|c|c|}
\hline \multicolumn{3}{|c|}{ Radiological Profile } & \multicolumn{3}{|c|}{ Chemical Profile } \\
\hline Radionuclide & $\begin{array}{r}\text { Total } \\
(\mathrm{Ci} / \mathrm{yr}) \\
\end{array}$ & $\begin{array}{c}\text { Released } \\
(\mathrm{Ci} / \mathrm{yr})\end{array}$ & Contaminant & $\begin{array}{r}\text { Total } \\
(\mathrm{kg} / \mathrm{yr}) \\
\end{array}$ & $\begin{array}{c}\text { Released } \\
(\mathrm{kg} / \mathrm{yr})\end{array}$ \\
\hline \multicolumn{6}{|c|}{$\begin{array}{l}\text { Treatment Site: LANL } \\
\text { Volume: } 1.1 \times 10^{3} \mathrm{~m}^{3} / \mathrm{yr}\end{array}$} \\
\hline Sr-90 & $3.7 \times 10^{1}$ & $2.0 \times 10^{-4}$ & Carbon tetrachloride & $4.2 \times 10^{1}$ & $2.1 \times 10^{-3}$ \\
\hline$Y-90$ & $3.7 \times 10^{1}$ & $2.0 \times 10^{-4}$ & Methyl alcohol & 5.4 & $1.6 \times 10^{-4}$ \\
\hline Cs-137 & $3.7 \times 10^{1}$ & $2.0 \times 10^{-4}$ & Butanol & 3.5 & $1.0 \times 10^{-4}$ \\
\hline $\mathrm{Ba}-137 \mathrm{~m}$ & $2.0 \times 10^{1}$ & $1.3 \times 10^{-4}$ & Methyl chloroform & $8.0 \times 10^{1}$ & $3.7 \times 10^{-3}$ \\
\hline Pm-147 & $2.3 \times 10^{1}$ & $1.5 \times 10^{-4}$ & methylene chloride & $2.7 \times 10^{2}$ & $1.4 \times 10^{-2}$ \\
\hline U-235 & $5.2 \times 10^{-3}$ & $3.4 \times 10^{-8}$ & 1,1,2-trichloro-1,2,2- & $1.3 \times 10^{2}$ & $6.3 \times 10^{-3}$ \\
\hline $\mathrm{U}-238$ & $2.9 \times 10^{-2}$ & $1.9 \times 10^{-7}$ & trifluoroethane & & \\
\hline $\mathrm{Pu}-238$ & $1.7 \times 10^{4}$ & $1.1 \times 10^{-1}$ & Ethyl benzene & 4.9 & $1.5 \times 10^{-4}$ \\
\hline $\mathrm{Pu}-239$ & $6.5 \times 10^{3}$ & $4.3 \times 10^{-2}$ & Toluene & 4.9 & $1.5 \times 10^{-4}$ \\
\hline Pu-240 & $2.1 \times 10^{3}$ & $1.4 \times 10^{-2}$ & Xylene & $1.1 \times 10^{1}$ & $3.3 \times 10^{-4}$ \\
\hline Pu-241 & $8.9 \times 10^{4}$ & $5.9 \times 10^{-1}$ & Cadmium & 3.5 & $4.0 \times 10^{-6}$ \\
\hline $\mathrm{Pu}-242$ & $2.6 \times 10^{-1}$ & $1.7 \times 10^{-6}$ & Mercury & $1.1 \times 10^{1}$ & $8.6 \times 10^{-9}$ \\
\hline $\mathrm{Am}-241$ & $1.9 \times 10^{4}$ & $1.3 \times 10^{-1}$ & Lead & $1.2 \times 10^{3}$ & $6.6 \times 10^{-4}$ \\
\hline \multicolumn{6}{|c|}{$\begin{array}{l}\text { Treatment Site: RFETS } \\
\text { Volume: } 6.0 \times 10^{2} \mathrm{~m}^{3} / \mathrm{yr}\end{array}$} \\
\hline U-235 & $9.6 \times 10^{-5}$ & $4.9 \times 10^{-10}$ & Carbon tetrachloride & 9.2 & $3.7 \times 10^{-4}$ \\
\hline $\mathrm{Pu}-238$ & $3.7 \times 10^{1}$ & $1.9 \times 10^{-4}$ & Methyl alcohol & 2.2 & $5.5 \times 10^{-5}$ \\
\hline Pu-239 & $1.0 \times 10^{3}$ & $5.2 \times 10^{-3}$ & Butanol & 1.4 & $3.5 \times 10^{-5}$ \\
\hline $\mathrm{Pu}-240$ & $2.5 \times 10^{2}$ & $1.3 \times 10^{-3}$ & Methyl chloroform & $2.9 \times 10^{1}$ & $1.1 \times 10^{-3}$ \\
\hline $\mathrm{Pu}-241$ & $6.6 \times 10^{3}$ & $3.4 \times 10^{-2}$ & Methylene chloride & $1.2 \times 10^{2}$ & $5.7 \times 10^{-3}$ \\
\hline $\mathrm{Pu}-242$ & $7.2 \times 10^{-3}$ & $3.7 \times 10^{-8}$ & 1,1,2-trichloro-1,2,2- & $6.1 \times 10^{1}$ & $2.7 \times 10^{-3}$ \\
\hline \multirow[t]{7}{*}{ Am-241 } & $1.1 \times 10^{3}$ & $5.6 \times 10^{-3}$ & trifluoroethane & & \\
\hline & & & Ethyl benzene & 2.0 & $5.1 \times 10^{-5}$ \\
\hline & & & Toluene & 2.0 & $5.1 \times 10^{-5}$ \\
\hline & & & Xylene & 4.4 & $1.1 \times 10^{-4}$ \\
\hline & & & Cadmium & 1.4 & $1.6 \times 10^{-6}$ \\
\hline & & & Mercury & 5.4 & $4.3 \times 10^{-9}$ \\
\hline & & & Lead & $5.9 \times 10^{4}$ & $3.0 \times 10^{-4}$ \\
\hline
\end{tabular}


TABLE B.4 (Cont.)

\begin{tabular}{|c|c|c|c|c|c|}
\hline \multicolumn{3}{|c|}{ Radiological Profile } & \multicolumn{3}{|c|}{ Chemical Profile } \\
\hline Radionuclide & $\begin{array}{c}\text { Total } \\
(\mathrm{Ci} / \mathrm{yr})\end{array}$ & $\begin{array}{c}\text { Released } \\
(\mathrm{Ci} / \mathrm{yr})\end{array}$ & Contaminant & $\begin{array}{c}\text { Total } \\
(\mathrm{kg} / \mathrm{yr})\end{array}$ & $\begin{array}{l}\text { Released } \\
(\mathrm{kg} / \mathrm{yr}) \\
\end{array}$ \\
\hline \multicolumn{6}{|c|}{$\begin{array}{l}\text { Treatment Site: SRS } \\
\text { Volume: } 5.7 \times 10^{2} \mathrm{~m}^{3} / \mathrm{yr}\end{array}$} \\
\hline$C-14$ & $1.04 \times 10^{-3}$ & $1.58 \times 10^{-4}$ & Carbon tetrachloride & 7.51 & $3.80 \times 10^{-4}$ \\
\hline Co- 60 & $1.15 \times 10^{-1}$ & $1.65 \times 10^{-10}$ & Methyl alcohol & $5.45 \times 10^{-3}$ & $5.75 \times 10^{-8}$ \\
\hline $\mathrm{Ni}-59$ & $4.05 \times 10^{-4}$ & $5.79 \times 10^{-13}$ & Butanol & $3.52 \times 10^{-3}$ & $3.71 \times 10^{-8}$ \\
\hline $\mathrm{Ni}-63$ & $4.94 \times 10^{-2}$ & $7.05 \times 10^{-11}$ & Methyl chloroform & $1.25 \times 10^{1}$ & $5.95 \times 10^{-4}$ \\
\hline Sr -90 & $1.69 \times 10^{2}$ & $3.37 \times 10^{-5}$ & Methylene chloride & $4.88 \times 10^{1}$ & $2.66 \times 10^{-3}$ \\
\hline Tc-99 & 2.01 & $3.92 \times 10^{-7}$ & 1,1,2-trichloro-1,2,2- & $2.06 \times 10^{1}$ & $1.09 \times 10^{-3}$ \\
\hline Cs-137 & $2.65 \times 10^{2}$ & $5.23 \times 10^{-5}$ & trifluoroethane & & \\
\hline Pm-147 & $3.09 \times 10^{-5}$ & $8.25 \times 10^{-11}$ & Ethyl benzene & $4.96 \times 10^{-3}$ & $6.09 \times 10^{-8}$ \\
\hline Eu-155 & $1.71 \times 10^{1}$ & $2.45 \times 10^{-8}$ & Toluene & $4.96 \times 10^{-3}$ & $6.09 \times 10^{-8}$ \\
\hline $\mathrm{Pb}-210$ & $1.43 \times 10^{-1}$ & $2.78 \times 10^{-8}$ & Xylene & $1.01 \times 10^{-2}$ & $1.17 \times 10^{-7}$ \\
\hline $\mathbf{R a}-226$ & $7.38 \times 10^{-1}$ & $1.44 \times 10^{-7}$ & Cadmium & $3.52 \times 10^{-3}$ & $3.45 \times 10^{-9}$ \\
\hline $\mathrm{Ra}-228$ & $3.31 \times 10^{-3}$ & $1.01 \times 10^{-10}$ & Mercury & 2.21 & $1.75 \times 10^{-9}$ \\
\hline Th-229 & $2.34 \times 10^{-2}$ & $4.77 \times 10^{-9}$ & Lead & $2.53 \times 10^{2}$ & $1.49 \times 10^{-6}$ \\
\hline Th-230 & $7.60 \times 10^{-4}$ & $5.39 \times 10^{-12}$ & & & \\
\hline Th-232 & $6.96 \times 10^{-3}$ & $1.26 \times 10^{-10}$ & & & \\
\hline $\mathrm{Pa}-231$ & $3.55 \times 10^{-2}$ & $6.91 \times 10^{-9}$ & & & \\
\hline U-232 & $6.17 \times 10^{-2}$ & $6.42 \times 10^{-9}$ & & & \\
\hline U-233 & $2.12 \times 10^{1}$ & $4.03 \times 10^{-6}$ & & & \\
\hline U-234 & $1.01 \times 10^{1}$ & $5.06 \times 10^{-7}$ & & & \\
\hline U-235 & $3.07 \times 10^{-3}$ & $3.62 \times 10^{-9}$ & & & \\
\hline U-236 & $1.55 \times 10^{-2}$ & $2.24 \times 10^{-11}$ & & & \\
\hline U-238 & $5.71 \times 10^{-3}$ & $1.07 \times 10^{-8}$ & & & \\
\hline Np-237 & 8.38 & $5.54 \times 10^{-5}$ & & & \\
\hline $\mathrm{Pu}-238$ & $1.58 \times 10^{5}$ & $1.59 \times 10^{-3}$ & & & \\
\hline Pu-239 & $3.35 \times 10^{3}$ & $2.11 \times 10^{-4}$ & & & \\
\hline $\mathrm{Pu}-240$ & $8.54 \times 10^{2}$ & $3.25 \times 10^{-5}$ & & & \\
\hline $\mathrm{Pu}-241$ & $2.55 \times 10^{4}$ & $1.16 \times 10^{-3}$ & & & \\
\hline $\mathrm{Pu}-242$ & $7.59 \times 10^{-5}$ & $1.37 \times 10^{-11}$ & & & \\
\hline Am-241 & $1.41 \times 10^{3}$ & $1.02 \times 10^{-4}$ & & & \\
\hline Am-243 & 1.43 & $1.32 \times 10^{-6}$ & & & \\
\hline $\mathrm{Cm}-244$ & $3.61 \times 10^{2}$ & $2.38 \times 10^{-5}$ & & & \\
\hline $\mathrm{Cm}-245$ & $1.09 \times 10^{-2}$ & $2.90 \times 10^{-8}$ & & & \\
\hline Cf-252 & $2.28 \times 10^{-2}$ & $6.09 \times 10^{-8}$ & & & \\
\hline
\end{tabular}


TABLE B.5 Projected Waste Loads and Release Profiles by Site in CH-TRUW Regionalized/Treatment to LDRs/Three Sites Alternative

Radiological Profile

\begin{tabular}{|c|c|c|}
\hline Radionuclide & $\begin{array}{c}\text { Total } \\
(\mathrm{Ci} / \mathrm{yr}) \\
\end{array}$ & $\begin{array}{c}\text { Released } \\
(\mathrm{Ci} / \mathrm{yr})\end{array}$ \\
\hline C-14 & $4.59 \times 10^{-1}$ & $8.68 \times 10^{-2}$ \\
\hline Sr-90 & $1.98 \times 10^{2}$ & $8.26 \times 10^{-4}$ \\
\hline $\mathrm{Cs}-137$ & $1.96 \times 10^{2}$ & $8.15 \times 10^{-4}$ \\
\hline Pm-147 & $1.37 \times 10^{-2}$ & $5.70 \times 10^{-8}$ \\
\hline $\mathrm{Ra}-228$ & $1.60 \times 10^{-2}$ & $6.68 \times 10^{-8}$ \\
\hline Th-229 & $3.75 \times 10^{-2}$ & $1.56 \times 10^{-7}$ \\
\hline Th-232 & $1.92 \times 10^{-2}$ & $8.01 \times 10^{-8}$ \\
\hline$U-233$ & $2.29 \times 10^{1}$ & $9.55 \times 10^{-5}$ \\
\hline U-234 & $1.54 \times 10^{1}$ & $6.42 \times 10^{-5}$ \\
\hline $\mathrm{U}-235$ & $4.91 \times 10^{-1}$ & $2.05 \times 10^{-6}$ \\
\hline U-236 & $3.99 \times 10^{-6}$ & $8.43 \times 10^{-11}$ \\
\hline U-238 & 1.70 & $7.33 \times 10^{-6}$ \\
\hline $\mathrm{Pu}-238$ & $2.31 \times 10^{4}$ & $9.69 \times 10^{-2}$ \\
\hline Pu-239 & $7.62 \times 10^{3}$ & $3.32 \times 10^{-2}$ \\
\hline $\mathrm{Pu}-240$ & $1.80 \times 10^{3}$ & $8.05 \times 10^{-3}$ \\
\hline Pu-241 & $1.17 \times 10^{4}$ & $6.31 \times 10^{-2}$ \\
\hline$A m-241$ & $1.43 \times 10^{3}$ & $7.24 \times 10^{-3}$ \\
\hline Am-243 & $1.28 \times 10^{-2}$ & $2.71 \times 10^{-7}$ \\
\hline $\mathrm{Cm}-244$ & $5.38 \times 10^{1}$ & $8.04 \times 10^{-4}$ \\
\hline $\mathrm{Cm}-245$ & 4.81 & $2.00 \times 10^{-5}$ \\
\hline Cf-252 & $1.01 \times 10^{1}$ & $4.21 \times 10^{-5}$ \\
\hline Sr-90 & $8.4 \times 10^{1}$ & $4.0 \times 10^{-4}$ \\
\hline $\mathrm{Y}-90$ & $3.1 \times 10^{1}$ & $2.0 \times 10^{-4}$ \\
\hline Ru-106 & $6.9 \times 10^{-2}$ & $2.6 \times 10^{-7}$ \\
\hline Cs-137 & $9.9 \times 10^{1}$ & $4.6 \times 10^{-4}$ \\
\hline $\mathrm{Ba}-137 \mathrm{~m}$ & $2.0 \times 10^{1}$ & $1.3 \times 10^{-4}$ \\
\hline Ce-144 & $4.9 \times 10^{-1}$ & $1.9 \times 10^{-6}$ \\
\hline Pm-147 & $2.4 \times 10^{2}$ & $9.8 \times 10^{-4}$ \\
\hline Th-232 & $2.9 \times 10^{-2}$ & $1.1 \times 10^{-7}$ \\
\hline$U-233$ & $7.9 \times 10^{1}$ & $2.9 \times 10^{-4}$ \\
\hline U-235 & $1.9 \times 10^{-2}$ & $8.9 \times 10^{-8}$ \\
\hline $\mathrm{U}-238$ & $4.1 \times 10^{-2}$ & $2.3 \times 10^{-7}$ \\
\hline Np-237 & $5.7 \times 10^{-2}$ & $2.1 \times 10^{-7}$ \\
\hline $\mathrm{Pu}-238$ & $2.3 \times 10^{4}$ & $1.3 \times 10^{-1}$ \\
\hline Pu-239 & $1.1 \times 10^{4}$ & $6.1 \times 10^{-2}$ \\
\hline
\end{tabular}

Chemical Profile

\begin{tabular}{lcc}
\hline Contaminant & $\begin{array}{c}\text { Total } \\
(\mathrm{kg} / \mathrm{yr})\end{array}$ & $\begin{array}{c}\text { Released } \\
(\mathrm{kg} / \mathrm{yr})\end{array}$ \\
\hline & & \\
\hline
\end{tabular}

Treatment Site: Hanford

Volume: $8.6 \times 10^{2} \mathrm{~m}^{3} / \mathrm{yr}$

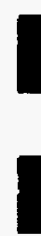

Treatment Site: INEL

Volume: $5.5 \times 10^{3} \mathrm{~m}^{3} / \mathrm{yr}$

Carbon tetrachloride

$1.92 \times 10^{1} \quad 8.79 \times 10^{-4}$

Methyl alcohol

$6.17 \times 10^{-1} \quad 1.43 \times 10^{-5}$

Butanol

$3.98 \times 10^{-1} \quad 9.25 \times 10^{-6}$

Methyl chloroform

$3.08 \times 10^{1}$

$1.37 \times 10^{-3}$

Methylene chloride

$1.29 \times 10^{2} \quad 6.21 \times 10^{-3}$

1,1,2-trichloro-1,2,2-

$5.57 \times 10^{1} \quad 2.59 \times 10^{-3}$

trifluoroethane

Ethyl benzene $\quad 5.61 \times 10^{-1} \quad 1.30 \times 10^{-5}$

Toluene

Xylene

$5.61 \times 10^{-1}$

$1.30 \times 10^{-5}$

Cadmium

1.23

$2.87 \times 10^{-5}$

Cadmium

$3.98 \times 10^{-1} \quad 5.55 \times 10^{-7}$

Mercury

5.68

$4.50 \times 10^{-9}$

Lead

$6.90 \times 10^{2} \quad 1.32 \times 10^{-4}$
Carbon tetrachloride

Methyl alcohol

Butanol

Methyl chloroform

Methylene chloride

1,1,2-trichloro-1,2,2-

trifluoroethane

Ethyl benzene

Toluene

Xylene

Cadmium

Mercury

Lead
$6.4 \times 10^{3}$

$1.9 \times 10^{-1}$

$1.6 \times 10^{1}$

$3.3 \times 10^{-4}$

$1.0 \times 10^{1}$

$2.1 \times 10^{-4}$

$1.9 \times 10^{4}$

$5.7 \times 10^{-1}$

$1.5 \times 10^{3}$

$7.7 \times 10^{-2}$

$6.8 \times 10^{3}$

$2.2 \times 10^{-1}$

$1.5 \times 10^{1}$

$3.1 \times 10^{-4}$

$1.5 \times 10^{1}$

$3.1 \times 10^{-4}$

$3.2 \times 10^{1}$

$6.8 \times 10^{-4}$

$1.0 \times 10^{1}$

$1.2 \times 10^{-5}$

$6.4 \times 10^{1}$

$5.1 \times 10^{-8}$

$8.1 \times 10^{4}$

$1.9 \times 10^{-3}$ 
TABLE B.5 (Cont.)

\begin{tabular}{|c|c|c|c|c|c|}
\hline \multicolumn{3}{|c|}{ Radiological Profile } & \multicolumn{3}{|c|}{ Chemical Profile } \\
\hline Radionuclide & $\begin{array}{l}\text { Total } \\
(\mathrm{Ci} / \mathrm{yr})\end{array}$ & $\begin{array}{l}\text { Released } \\
(\mathrm{Ci} / \mathrm{yr})\end{array}$ & Contaminant & $\begin{array}{c}\text { Total } \\
(\mathrm{kg} / \mathrm{yr})\end{array}$ & $\begin{array}{c}\text { Released } \\
(\mathrm{kg} / \mathrm{yr})\end{array}$ \\
\hline \multicolumn{6}{|c|}{$\begin{array}{l}\text { Treatment Site: INEL (continued) } \\
\text { Volume: } 5.5 \times 10^{3} \mathrm{~m}^{3} / \mathrm{yr}\end{array}$} \\
\hline $\mathrm{Pu}-240$ & $3.2 \times 10^{3}$ & $1.8 \times 10^{-2}$ & & & \\
\hline $\mathrm{Pu}-241$ & $1.2 \times 10^{5}$ & $7.2 \times 10^{-1}$ & & & \\
\hline $\mathrm{Pu}-242$ & $3.6 \times 10^{-1}$ & $2.1 \times 10^{-6}$ & & & \\
\hline Am-241 & $2.8 \times 10^{4}$ & $1.6 \times 10^{-1}$ & & & \\
\hline $\mathrm{Cm}-244$ & $9.9 \times 10^{1}$ & $3.7 \times 10^{-4}$ & & & \\
\hline Cf -252 & $5.7 \times 10^{-3}$ & $2.1 \times 10^{-8}$ & & & \\
\hline \multicolumn{6}{|c|}{$\begin{array}{l}\text { Treatment Site: SRS } \\
\text { Volume: } 5.7 \times 10^{2} \mathrm{~m}^{3} / \mathrm{yr}\end{array}$} \\
\hline C-14 & $1.04 \times 10^{-3}$ & $1.58 \times 10^{-4}$ & Carbon tetrachloride & 7.51 & $3.80 \times 10^{-4}$ \\
\hline $\mathrm{Co}-60$ & $1.15 \times 10^{-1}$ & $1.65 \times 10^{-10}$ & Methyl alcohol & $5.45 \times 10^{-3}$ & $5.75 \times 10^{-8}$ \\
\hline $\mathrm{Ni}-59$ & $4.05 \times 10^{-4}$ & $5.79 \times 10^{-13}$ & Butanol & $3.52 \times 10^{-3}$ & $3.71 \times 10^{-8}$ \\
\hline $\mathrm{Ni}-63$ & $4.94 \times 10^{-2}$ & $7.05 \times 10^{-11}$ & Methyl chloroform & $1.25 \times 10^{1}$ & $5.95 \times 10^{-4}$ \\
\hline Sr-90 & $1.69 \times 10^{2}$ & $3.37 \times 10^{-5}$ & Methylene chloride & $4.88 \times 10^{1}$ & $2.66 \times 10^{-3}$ \\
\hline Tc-99 & 2.01 & $3.92 \times 10^{-7}$ & 1,1,2-trichloro-1,2,2- & $2.06 \times 10^{1}$ & $1.09 \times 10^{-3}$ \\
\hline Cs- 137 & $2.65 \times 10^{2}$ & $5.23 \times 10^{-5}$ & trifluoroethane & & \\
\hline $\mathrm{Pm}-147$ & $3.09 \times 10^{-5}$ & $8.25 \times 10^{-11}$ & Ethyl benzene & $4.96 \times 10^{-3}$ & $6.09 \times 10^{-8}$ \\
\hline Eu-155 & $1.71 \times 10^{1}$ & $2.45 \times 10^{-8}$ & Toluene & $4.96 \times 10^{-3}$ & $6.09 \times 10^{-8}$ \\
\hline $\mathrm{Pb}-210$ & $1.43 \times 10^{-1}$ & $2.78 \times 10^{-8}$ & Xylene & $1.01 \times 10^{-2}$ & $1.17 \times 10^{-7}$ \\
\hline $\mathrm{Ra}-226$ & $7.38 \times 10^{-1}$ & $1.44 \times 10^{-7}$ & Cadmium & $3.52 \times 10^{-3}$ & $3.45 \times 10^{-9}$ \\
\hline $\mathrm{Ra}-228$ & $3.31 \times 10^{-3}$ & $1.01 \times 10^{-10}$ & Mercury & 2.21 & $1.75 \times 10^{-9}$ \\
\hline Th-229 & $2.34 \times 10^{-2}$ & $4.77 \times 10^{-9}$ & Lead & $2.53 \times 10^{2}$ & $1.49 \times 10^{-6}$ \\
\hline Th-230 & $7.60 \times 10^{-4}$ & $5.39 \times 10^{-12}$ & & & \\
\hline Th-232 & $6.96 \times 10^{-3}$ & $1.26 \times 10^{-10}$ & & & \\
\hline $\mathrm{Pa}-231$ & $3.55 \times 10^{-2}$ & $6.91 \times 10^{-9}$ & & & \\
\hline U-232 & $6.17 \times 10^{-2}$ & $6.42 \times 10^{-9}$ & & & \\
\hline U-233 & $2.12 \times 10^{1}$ & $4.03 \times 10^{-6}$ & & & \\
\hline U-234 & $1.01 \times 10^{1}$ & $5.06 \times 10^{-7}$ & & & \\
\hline U-235 & $3.07 \times 10^{-3}$ & $3.62 \times 10^{-9}$ & & & \\
\hline U-236 & $1.55 \times 10^{-2}$ & $2.24 \times 10^{-11}$ & & & \\
\hline U-238 & $5.71 \times 10^{-3}$ & $1.07 \times 10^{-8}$ & & & \\
\hline$N p-237$ & 8.38 & $5.54 \times 10^{-5}$ & & & \\
\hline Pu-238 & $1.58 \times 10^{5}$ & $1.59 \times 10^{-3}$ & & & \\
\hline Pu-239 & $3.35 \times 10^{3}$ & $2.11 \times 10^{-4}$ & & & \\
\hline Pu-240 & $8.54 \times 10^{2}$ & $3.25 \times 10^{-5}$ & & & \\
\hline Pu-241 & $2.55 \times 10^{4}$ & $1.16 \times 10^{-3}$ & & & \\
\hline Pu-242 & $7.59 \times 10^{-5}$ & $1.37 \times 10^{-11}$ & & & \\
\hline Am-241 & $1.41 \times 10^{3}$ & $1.02 \times 10^{-4}$ & & & \\
\hline Am-243 & 1.43 & $1.32 \times 10^{-6}$ & & & \\
\hline $\mathrm{Cm}-244$ & $3.61 \times 10^{2}$ & $2.38 \times 10^{-5}$ & & & \\
\hline $\mathrm{Cm}-245$ & $1.09 \times 10^{-2}$ & $2.90 \times 10^{-8}$ & & & \\
\hline Cf- 252 & $2.28 \times 10^{-2}$ & $6.09 \times 10^{-8}$ & & & \\
\hline
\end{tabular}


TABLE B.6 Projected Waste Load and Release Profiles by Site in CH-TRUW Centralized/Treatment to LDRs/One Site Alternative

\begin{tabular}{|c|c|c|c|c|c|}
\hline \multicolumn{3}{|c|}{ Radiological Profile } & \multicolumn{3}{|c|}{ Chemical Profile } \\
\hline Radionuclide & $\begin{array}{l}\text { Total } \\
(\mathrm{Ci} / \mathrm{yr})\end{array}$ & $\begin{array}{l}\text { Released } \\
(\mathrm{Ci} / \mathrm{yr})\end{array}$ & Contaminant & $\begin{array}{c}\text { Total } \\
(\mathrm{kg} / \mathrm{yr})\end{array}$ & $\begin{array}{c}\text { Released } \\
(\mathrm{kg} / \mathrm{yr})\end{array}$ \\
\hline \multicolumn{6}{|c|}{$\begin{array}{c}\text { Treatment Site: WIPP } \\
\text { Volume: } 8.2 \times 10^{3} \mathrm{~m}^{3} / \mathrm{yr}\end{array}$} \\
\hline Sr-90 & $3.7 \times 10^{3}$ & $3.3 \times 10^{-3}$ & Carbon tetrachloride & $7.8 \times 10^{3}$ & $8.7 \times 10^{-2}$ \\
\hline$Y-90$ & $3.6 \times 10^{3}$ & $3.1 \times 10^{-3}$ & Methyl alcohol & $1.8 \times 10^{1}$ & $1.8 \times 10^{-4}$ \\
\hline Ru-106 & $4.4 \times 10^{1}$ & $3.5 \times 10^{-5}$ & Butanol & $1.2 \times 10^{1}$ & $1.2 \times 10^{-4}$ \\
\hline Rh-106 & $4.4 \times 10^{1}$ & $3.4 \times 10^{-5}$ & Methyl chloroform & $2.3 \times 10^{4}$ & $2.5 \times 10^{-1}$ \\
\hline Cs-137 & $2.9 \times 10^{3}$ & $2.7 \times 10^{-3}$ & Methylene chloride & $1.9 \times 10^{3}$ & $6.6 \times 10^{-2}$ \\
\hline Ba-137m & $2.5 \times 10^{3}$ & $2.1 \times 10^{-3}$ & 1,1,2-trichloro-1,2,2- & $8.5 \times 10^{3}$ & $1.1 \times 10^{-1}$ \\
\hline $\mathrm{Ce}-144$ & $4.4 \times 10^{2}$ & $3.5 \times 10^{-4}$ & trifluoroethane & & \\
\hline Pr-144 & $4.4 \times 10^{2}$ & $3.4 \times 10^{-4}$ & Ethyl benzene & $1.6 \times 10^{1}$ & $1.9 \times 10^{-4}$ \\
\hline Pm-147 & $3.5 \times 10^{3}$ & $3.6 \times 10^{-3}$ & Toluene & $1.6 \times 10^{1}$ & $1.9 \times 10^{-4}$ \\
\hline Th-232 & $3.0 \times 10^{-2}$ & $1.1 \times 10^{-7}$ & Xylene & $3.4 \times 10^{1}$ & $3.8 \times 10^{-4}$ \\
\hline U-233 & $7.9 \times 10^{1}$ & $2.9 \times 10^{-4}$ & Cadmium & $1.2 \times 10^{1}$ & $1.2 \times 10^{-5}$ \\
\hline U-235 & $3.4 \times 10^{-2}$ & $1.3 \times 10^{-7}$ & Mercury & $7.5 \times 10^{1}$ & $5.9 \times 10^{-8}$ \\
\hline $\mathrm{U}-238$ & $1.4 \times 10^{-1}$ & $3.3 \times 10^{-7}$ & Lead & $9.4 \times 10^{4}$ & $1.1 \times 10^{-2}$ \\
\hline Np-237 & $4.9 \times 10^{-1}$ & $1.1 \times 10^{-5}$ & & & \\
\hline Pu-238 & $1.2 \times 10^{5}$ & 2.5 & & & \\
\hline Pu-239 & $1.4 \times 10^{4}$ & $1.2 \times 10^{-1}$ & & & \\
\hline Pu-240 & $4.1 \times 10^{3}$ & $3.4 \times 10^{-2}$ & & & \\
\hline Pu-241 & $1.5 \times 10^{5}$ & 1.3 & & & \\
\hline Pu-242 & $9.1 \times 10^{-1}$ & $1.5 \times 10^{-5}$ & . & & \\
\hline Am-241 & $2.8 \times 10^{4}$ & $1.7 \times 10^{-1}$ & & & \\
\hline $\mathrm{Cm}-244$ & $3.6 \times 10^{2}$ & $6.6 \times 10^{-3}$ & & & \\
\hline Cf -252 & 3.3 & $7.9 \times 10^{-5}$ & & & \\
\hline
\end{tabular}


TABLE B.7 Projected Waste Loads and Release Profiles by Site in RH-TRUW No Action Alternative

\begin{tabular}{|c|c|c|c|c|c|}
\hline \multicolumn{3}{|c|}{ Radiological Profile } & \multicolumn{3}{|c|}{ Chemical Profile } \\
\hline Radionuclide & $\begin{array}{l}\text { Total } \\
(\mathrm{Ci} / \mathrm{yr}) \\
\end{array}$ & $\begin{array}{c}\text { Released } \\
(\mathrm{Ci} / \mathrm{yr}) \\
\end{array}$ & Contaminant & $\begin{array}{c}\text { Total } \\
(\mathrm{kg} / \mathrm{yr}) \\
\end{array}$ & $\begin{array}{c}\text { Released } \\
(\mathrm{kg} / \mathrm{yr})\end{array}$ \\
\hline \multicolumn{6}{|c|}{$\begin{array}{l}\text { Treatment Site: ANL-E } \\
\text { Volume: } 1.7 \times 10^{1} \mathrm{~m}^{3} / \mathrm{yr}\end{array}$} \\
\hline Cs-137 & $1.6 \times 10^{2}$ & $3.1 \times 10^{-8}$ & Carbon tetrachloride & 2.3 & $2.3 \times 10^{-5}$ \\
\hline $\mathrm{U}-238$ & 1.9 & $3.7 \times 10^{-10}$ & Methyl chloroform & 3.7 & $3.7 \times 10^{-5}$ \\
\hline $\mathrm{Pu}-239$ & 2.6 & $5.1 \times 10^{-10}$ & Methylene chloride & 1.5 & $1.5 \times 10^{-5}$ \\
\hline $\mathrm{Pu}-240$ & 1.9 & $3.7 \times 10^{-10}$ & 1,1,2-trichloro-1,2,2- & 3.4 & $3.4 \times 10^{-5}$ \\
\hline $\mathrm{Pu}-241$ & $2.4 \times 10^{1}$ & $4.8 \times 10^{-9}$ & trifluoroethane & & \\
\hline & & & Lead & 3.7 & $7.5 \times 10^{-10}$ \\
\hline \multicolumn{6}{|c|}{$\begin{array}{l}\text { Treatment Site: Hanford } \\
\text { Volume: } 5.8 \times 10^{2} \mathrm{~m}^{3} / \mathrm{yr}\end{array}$} \\
\hline Co- 60 & $2.20 \times 10^{3}$ & $4.40 \times 10^{-7}$ & Carbon tetrachloride & 4.62 & $4.62 \times 10^{-5}$ \\
\hline Sr-90 & $4.22 \times 10^{4}$ & $8.45 \times 10^{-6}$ & Methyl chloroform & $1.15 \times 10^{1}$ & $1.15 \times 10^{-4}$ \\
\hline Cs-137 & $4.56 \times 10^{4}$ & $9.13 \times 10^{-6}$ & Methylene chloride & $7.21 \times 10^{1}$ & $7.21 \times 10^{-4}$ \\
\hline $\mathrm{U}-233$ & 2.71 & $5.42 \times 10^{-10}$ & 1,1,2-trichloro-1,2,2 & $3.16 \times 10^{1}$ & $3.16 \times 10^{-4}$ \\
\hline $\mathrm{U}-234$ & 8.45 & $1.69 \times 10^{-9}$ & trifluoroethane & & \\
\hline Pu-238 & $3.05 \times 10^{2}$ & $6.11 \times 10^{-8}$ & Mercury & 3.55 & $7.10 \times 10^{-10}$ \\
\hline Pu-239 & $2.19 \times 10^{3}$ & $4.38 \times 10^{-7}$ & Lead & $3.33 \times 10^{4}$ & $6.65 \times 10^{-6}$ \\
\hline $\mathrm{Pu}-240$ & $1.09 \times 10^{3}$ & $2.18 \times 10^{-7}$ & & & \\
\hline Pu-241 & $3.05 \times 10^{4}$ & $6.10 \times 10^{-6}$ & & & \\
\hline Am-241 & $1.26 \times 10^{3}$ & $2.53 \times 10^{-7}$ & & & \\
\hline
\end{tabular}


TABLE B.7 (Cont.)

\begin{tabular}{|c|c|c|c|c|c|}
\hline \multicolumn{3}{|c|}{ Radiological Profile } & \multicolumn{3}{|c|}{ Chemical Profile } \\
\hline Radionuclide & $\begin{array}{c}\text { Total } \\
(\mathrm{Ci} / \mathrm{yr})\end{array}$ & $\begin{array}{l}\text { Released } \\
(\mathrm{Ci} / \mathrm{yr})\end{array}$ & Contaminant & $\begin{array}{c}\text { Total } \\
(\mathrm{kg} / \mathrm{yr})\end{array}$ & $\begin{array}{c}\text { Released } \\
(\mathrm{kg} / \mathrm{yr})\end{array}$ \\
\hline \multicolumn{6}{|c|}{$\begin{array}{l}\begin{array}{l}\text { Treatment Site: INEL } \\
\text { Volume: } 2.3 \times 10^{1} \mathrm{~m}^{3} / \mathrm{yr}\end{array} \\
\end{array}$} \\
\hline $\mathrm{Cr}_{\mathrm{r}-51}$ & $3.9 \times 10^{-1}$ & $7.8 \times 10^{-11}$ & Carbon tetrachloride & $5.8 \times 10^{-1}$ & $5.8 \times 10^{-6}$ \\
\hline $\mathrm{Mn}-54$ & $2.5 \times 10^{4}$ & $5.1 \times 10^{-6}$ & Methyl alcohol & $2.9 \times 10^{-1}$ & $2.9 \times 10^{-6}$ \\
\hline $\mathrm{Fe}-59$ & $3.9 \times 10^{-1}$ & $7.8 \times 10^{-11}$ & Butanol & $1.9 \times 10^{-1}$ & $1.9 \times 10^{-6}$ \\
\hline $\mathrm{Co}-58$ & 6.4 & $1.3 \times 10^{-9}$ & Methyl chloroform & 1.9 & $1.8 \times 10^{-5}$ \\
\hline Co-60 & 2.5 & $5.1 \times 10^{-10}$ & Methylene chloride & 2.8 & $2.8 \times 10^{-5}$ \\
\hline $\mathrm{Ni}-63$ & $2.3 \times 10^{1}$ & $4.6 \times 10^{-9}$ & 1,1,2-trichloro-1,2,2- & 2.2 & $2.2 \times 10^{-5}$ \\
\hline Sr-90 & $3.7 \times 10^{3}$ & $7.4 \times 10^{-7}$ & trifluoroethane & & \\
\hline$Y-90$ & $1.2 \times 10^{1}$ & $2.4 \times 10^{-9}$ & Ethyl benzene & $2.7 \times 10^{-1}$ & $2.7 \times 10^{-6}$ \\
\hline $\mathrm{Nb}-95$ & $4.1 \times 10^{-2}$ & $8.3 \times 10^{-12}$ & Toluene & $2.7 \times 10^{-1}$ & $2.7 \times 10^{-6}$ \\
\hline Tc-99 & $8.7 \times 10^{-3}$ & $1.7 \times 10^{-12}$ & Xylene & $5.9 \times 10^{-1}$ & $5.9 \times 10^{-6}$ \\
\hline $\mathrm{Ru}-106$ & $9.4 \times 10^{2}$ & $1.9 \times 10^{-7}$ & Cadmium & $1.9 \times 10^{-1}$ & $3.8 \times 10^{-11}$ \\
\hline $\mathrm{Rh}-106$ & $7.4 \times 10^{-2}$ & $1.5 \times 10^{-11}$ & Mercury & $6.1 \times 10^{-2}$ & $1.2 \times 10^{-11}$ \\
\hline$S b-125$ & $3.5 \times 10^{-1}$ & $6.9 \times 10^{-11}$ & Lead & $6.2 \times 10^{2}$ & $1.2 \times 10^{-7}$ \\
\hline Cs-134 & $5.3 \times 10^{1}$ & $1.1 \times 10^{-8}$ & & & \\
\hline Cs-137 & $1.0 \times 10^{3}$ & $2.1 \times 10^{-7}$ & & & \\
\hline $\mathrm{Ba}-137 \mathrm{~m}$ & 9.4 & $1.9 \times 10^{-9}$ & & & \\
\hline Ce-144 & $2.2 \times 10^{2}$ & $4.5 \times 10^{-8}$ & & & \\
\hline Pr-144 & $8.7 \times 10^{-1}$ & $1.7 \times 10^{-10}$ & & & \\
\hline $\mathrm{Pm}-147$ & $1.2 \times 10^{4}$ & $2.4 \times 10^{-6}$ & & & \\
\hline Eu-154 & $8.7 \times 10^{-2}$ & $1.7 \times 10^{-11}$ & & & \\
\hline Eu-155 & $4.4 \times 10^{-2}$ & $8.7 \times 10^{-12}$ & & & \\
\hline Th-232 & $3.9 \times 10^{-6}$ & $7.8 \times 10^{-16}$ & & & \\
\hline U-233 & $1.4 \times 10^{-2}$ & $2.7 \times 10^{-12}$ & & & \\
\hline U-235 & $2.9 \times 10^{-2}$ & $5.9 \times 10^{-12}$ & & & \\
\hline U-236 & $2.8 \times 10^{-4}$ & $5.5 \times 10^{-14}$ & & & \\
\hline U-238 & $3.2 \times 10^{-3}$ & $6.4 \times 10^{-13}$ & & & \\
\hline Np-237 & $2.9 \times 10^{-4}$ & $5.9 \times 10^{-14}$ & & & \\
\hline $\mathrm{Pu}-238$ & 4.4 & $8.7 \times 10^{-10}$ & & & \\
\hline $\mathrm{Pu}-239$ & 1.7 & $3.5 \times 10^{-10}$ & & & \\
\hline $\mathrm{Pu}-240$ & 7.8 & $1.6 \times 10^{-9}$ & & & \\
\hline $\mathrm{Pu}-241$ & $4.4 \times 10^{3}$ & $8.7 \times 10^{-7}$ & & & \\
\hline
\end{tabular}


TABLE B.7 (Cont.)

\begin{tabular}{|c|c|c|c|c|c|}
\hline \multicolumn{3}{|c|}{ Radiological Profile } & \multicolumn{3}{|c|}{ Chemical Profile } \\
\hline Radionuclide & $\begin{array}{l}\text { Total } \\
(\mathrm{Ci} / \mathrm{yr}) \\
\end{array}$ & $\begin{array}{c}\text { Released } \\
\text { (Ci/yr) }\end{array}$ & Contaminant & $\begin{array}{l}\text { Total } \\
(\mathrm{kg} / \mathrm{yr})\end{array}$ & $\begin{array}{c}\text { Released } \\
(\mathrm{kg} / \mathrm{yr})\end{array}$ \\
\hline \multicolumn{6}{|c|}{$\begin{array}{l}\text { Treatment Site: LANL } \\
\text { Volume: } 5.0 \times 10^{-1} \mathrm{~m}^{3} / \mathrm{yr}\end{array}$} \\
\hline $\mathrm{Sr}-90$ & $1.2 \times 10^{1}$ & $2.4 \times 10^{-9}$ & Carbon tetrachloride & $2.3 \times 10^{-2}$ & $2.3 \times 10^{-7}$ \\
\hline Y-90 & $1.2 \times 10^{1}$ & $2.4 \times 10^{-9}$ & Methyl chloroform & $3.4 \times 10^{-2}$ & $3.4 \times 10^{-7}$ \\
\hline Cs- 137 & 9.0 & $1.8 \times 10^{-9}$ & Methylene chloride & $1.6 \times 10^{-1}$ & $1.7 \times 10^{-6}$ \\
\hline $\mathrm{Ba}-137 \mathrm{~m}$ & 8.0 & $1.6 \times 10^{-9}$ & 1,1,2-trichloro-1,2,2- & $6.7 \times 10^{-2}$ & $6.7 \times 10^{-7}$ \\
\hline Pm-147 & 9.0 & $1.8 \times 10^{-9}$ & trifluoroethane & & \\
\hline U-235 & $6.5 \times 10^{-5}$ & $1.3 \times 10^{-14}$ & Mercury & $7.5 \times 10^{-3}$ & $1.5 \times 10^{-12}$ \\
\hline U-238 & $6.0 \times 10^{-6}$ & $1.2 \times 10^{-15}$ & Lead & $8.3 \times 10^{-1}$ & $1.7 \times 10^{-10}$ \\
\hline Pu-238 & $4.6 \times 10^{-2}$ & $9.2 \times 10^{-12}$ & & & \\
\hline Pu-239 & $5.5 \times 10^{-1}$ & $1.1 \times 10^{-10}$ & & & \\
\hline $\mathrm{Pu}-240$ & $1.8 \times 10^{-1}$ & $3.5 \times 10^{-11}$ & & & \\
\hline Pu-241 & 7.5 & $1.5 \times 10^{-9}$ & & & \\
\hline $\mathrm{Pu}-242$ & $3.4 \times 10^{-5}$ & $6.8 \times 10^{-15}$ & & & \\
\hline \multicolumn{6}{|c|}{$\begin{array}{c}\text { Treatment Site: ORR } \\
\text { Volume: } 1.4 \times 10^{1} \mathrm{~m}^{3} / \mathrm{yr}\end{array}$} \\
\hline $\mathrm{Co}-60$ & $3.2 \times 10^{1}$ & $6.4 \times 10^{-9}$ & Carbon tetrachloride & $6.3 \times 10^{2}$ & $6.3 \times 10^{-3}$ \\
\hline Sr-90 & $1.1 \times 10^{3}$ & $2.2 \times 10^{-7}$ & Methyl chloroform & $1.9 \times 10^{3}$ & $1.9 \times 10^{-2}$ \\
\hline Cs-137 & $1.2 \times 10^{3}$ & $2.4 \times 10^{-7}$ & 1,1,2-trichloro-1,2,2 & $6.3 \times 10^{2}$ & $6.3 \times 10^{-3}$ \\
\hline Eu-152 & $1.5 \times 10^{2}$ & $3.1 \times 10^{-8}$ & trifluoroethane & & \\
\hline Eu-154 & $9.2 \times 10^{1}$ & $1.8 \times 10^{-8}$ & & & \\
\hline Th-232 & $3.6 \times 10^{-2}$ & $7.3 \times 10^{-12}$ & & & \\
\hline $\mathrm{U}-233$ & 1.3 & $2.6 \times 10^{-10}$ & & & \\
\hline U-235 & $3.4 \times 10^{-6}$ & $6.7 \times 10^{-16}$ & & & \\
\hline U-238 & $6.6 \times 10^{-6}$ & $1.3 \times 10^{-15}$ & & & \\
\hline Np-237 & $1.3 \times 10^{-3}$ & $2.5 \times 10^{-13}$ & & & \\
\hline Pu-238 & 5.3 & $1.1 \times 10^{-9}$ & & & \\
\hline Pu-239 & 2.2 & $4.5 \times 10^{-10}$ & & & \\
\hline $\mathbf{P u}-240$ & $2.9 \times 10^{-3}$ & $5.9 \times 10^{-13}$ & & & \\
\hline $\mathrm{Pu}-241$ & $7.3 \times 10^{-5}$ & $1.5 \times 10^{-14}$ & & & \\
\hline Am-241 & $4.3 \times 10^{-1}$ & $8.7 \times 10^{-11}$ & & & \\
\hline $\mathrm{Cm}-244$ & $2.8 \times 10^{1}$ & $5.6 \times 10^{-9}$ & & & \\
\hline Cf- 252 & $5.7 \times 10^{-1}$ & $1.1 \times 10^{-10}$ & & & \\
\hline \multicolumn{6}{|c|}{$\begin{array}{l}\text { Treatment Site: SRS } \\
\text { Volume: } 7.1 \times 10^{-1} \mathrm{~m}^{3} / \mathrm{yr}\end{array}$} \\
\hline H-3 & $1.39 \times 10^{-2}$ & $2.79 \times 10^{-12}$ & & & \\
\hline Sr-90 & 6.85 & $1.37 \times 10^{-9}$ & & & \\
\hline Cs- 137 & 6.86 & $1.37 \times 10^{-9}$ & & & \\
\hline Pm-147 & 1.34 & $2.67 \times 10^{-10}$ & & & \\
\hline Pu-238 & 8.82 & $1.76 \times 10^{-9}$ & & & \\
\hline $\mathrm{Pu}-239$ & $1.06 \times 10^{-2}$ & $2.12 \times 10^{-12}$ & & & \\
\hline $\mathrm{Pu}-240$ & $5.06 \times 10^{-4}$ & $1.01 \times 10^{-13}$ & & & \\
\hline Am-241 & $6.79 \times 10^{-2}$ & $1.36 \times 10^{-11}$ & & & \\
\hline $\mathrm{Cm}-244$ & 4.68 & $9.36 \times 10^{-10}$ & & & \\
\hline
\end{tabular}


TABLE B.8 Projected Waste Loads and Release Profiles by Site in RH-TRUW Decentralized/Treatment to WIPP-WAC/Six Sites Alternative

\begin{tabular}{|c|c|c|c|c|c|}
\hline \multicolumn{3}{|c|}{ Radiological Profile } & \multicolumn{3}{|c|}{ Chemical Profile } \\
\hline Radionuclide & $\begin{array}{c}\text { Total } \\
(\mathrm{Ci} / \mathrm{yr}) \\
\end{array}$ & $\begin{array}{c}\text { Released } \\
(\mathrm{Ci} / \mathrm{yr})\end{array}$ & Contaminant & $\begin{array}{c}\text { Total } \\
(\mathrm{kg} / \mathrm{yr})\end{array}$ & $\begin{array}{c}\text { Released } \\
\text { (kg/yr) }\end{array}$ \\
\hline \multicolumn{6}{|c|}{$\begin{array}{l}\text { Treatment Site: ANL-E } \\
\text { Volume: } 3.4 \times 10^{1} \mathrm{~m}^{3} / \mathrm{yr}\end{array}$} \\
\hline Cs-137 & $3.1 \times 10^{2}$ & $1.5 \times 10^{-7}$ & Carbon tetrachloride & 4.6 & $1.5 \times 10^{-4}$ \\
\hline $\mathrm{U}-238$ & 3.7 & $1.8 \times 10^{-9}$ & Methyl chloroform & 7.5 & $2.4 \times 10^{-4}$ \\
\hline Pu-239 & 5.1 & $2.4 \times 10^{-9}$ & Methylene chloride & 2.9 & $9.6 \times 10^{-5}$ \\
\hline $\mathrm{Pu}-240$ & 3.7 & $1.8 \times 10^{-9}$ & 1,1,2-trichloro-1,2,2- & 6.8 & $2.2 \times 10^{-4}$ \\
\hline \multirow[t]{3}{*}{ Pu-241 } & $4.8 \times 10^{1}$ & $2.2 \times 10^{-8}$ & trifluoroethane & & \\
\hline & & & Lead & 7.5 & $3.5 \times 10^{-9}$ \\
\hline & & \multicolumn{2}{|c|}{$\begin{array}{l}\text { Treatment Site: Hanford } \\
\text { Volume: } 5.8 \times 10^{2} \mathrm{~m}^{3} / \mathrm{yr}\end{array}$} & & \\
\hline Co- 60 & $4.43 \times 10^{3}$ & $1.90 \times 10^{-6}$ & Carbon tetrachloride & 9.24 & $2.86 \times 10^{-4}$ \\
\hline Sr -90 & $8.51 \times 10^{4}$ & $3.66 \times 10^{-5}$ & Methyl chloroform & $2.29 \times 10^{1}$ & $7.10 \times 10^{-4}$ \\
\hline Cs-137 & $9.20 \times 10^{4}$ & $3.95 \times 10^{-5}$ & Methylene chloride & $1.44 \times 10^{2}$ & $4.47 \times 10^{-3}$ \\
\hline U-233 & 5.46 & $2.35 \times 10^{-9}$ & 1,1,2-trichloro-1,2,2- & $6.32 \times 10^{1}$ & $1.96 \times 10^{-3}$ \\
\hline$U-234$ & $1.70 \times 10^{1}$ & $7.31 \times 10^{-9}$ & trifluoroethane & & \\
\hline Pu-238 & $6.15 \times 10^{2}$ & $2.64 \times 10^{-7}$ & Mercury & 7.10 & $3.05 \times 10^{-9}$ \\
\hline Pu-239 & $4.42 \times 10^{3}$ & $1.90 \times 10^{-6}$ & Lead & $6.65 \times 10^{4}$ & $2.86 \times 10^{-5}$ \\
\hline Pu-240 & $2.19 \times 10^{3}$ & $9.42 \times 10^{-7}$ & & & \\
\hline Pu-241 & $6.15 \times 10^{4}$ & $2.64 \times 10^{-5}$ & & & \\
\hline Am-241 & $2.55 \times 10^{3}$ & $1.09 \times 10^{-6}$ & & & \\
\hline
\end{tabular}


TABLE B.8 (Cont.)

\begin{tabular}{|c|c|c|c|c|c|}
\hline \multicolumn{3}{|c|}{ Radiological Profile } & \multicolumn{3}{|c|}{ Chemical Profile } \\
\hline Radionuclide & $\begin{array}{c}\text { Total } \\
(\mathrm{Ci} / \mathrm{yr}) \\
\end{array}$ & $\begin{array}{c}\text { Released } \\
(\mathrm{Ci} / \mathrm{yr})\end{array}$ & Contaminant & $\begin{array}{c}\text { Total } \\
(\mathrm{kg} / \mathrm{yr})\end{array}$ & $\begin{array}{c}\text { Released } \\
(\mathrm{kg} / \mathrm{yr})\end{array}$ \\
\hline \multicolumn{6}{|c|}{$\begin{array}{c}\text { Treatment Site: INEL } \\
\text { Volume: } 5.7 \times 10^{1} \mathrm{~m}^{3} / \mathrm{yr}\end{array}$} \\
\hline $\mathrm{Cr}-51$ & $9.7 \times 10^{-1}$ & $4.3 \times 10^{-10}$ & Carbon tetrachloride & 1.3 & $4.3 \times 10^{-5}$ \\
\hline $\mathrm{Mn}-54$ & $6.3 \times 10^{4}$ & $2.8 \times 10^{-5}$ & Methyl alcohol & $6.1 \times 10^{-1}$ & $3.1 \times 10^{-5}$ \\
\hline $\mathrm{Fe}-59$ & $9.7 \times 10^{-1}$ & $4.3 \times 10^{-10}$ & Butanol & $3.9 \times 10^{-1}$ & $1.9 \times 10^{-5}$ \\
\hline Co-58 & $1.6 \times 10^{1}$ & $7.0 \times 10^{-9}$ & Methyl chloroform & 4.3 & $1.4 \times 10^{-4}$ \\
\hline Co-60 & 6.3 & $2.8 \times 10^{-9}$ & Methylene chloride & 8.2 & $2.8 \times 10^{-4}$ \\
\hline $\mathrm{Ni}-63$ & $5.7 \times 10^{1}$ & $2.5 \times 10^{-8}$ & 1,1,2-trichloro-1,2,2- & 5.7 & $1.9 \times 10^{-4}$ \\
\hline Sr -90 & $9.1 \times 10^{3}$ & $4.0 \times 10^{-6}$ & trifluoroethane & & \\
\hline Y-90 & $2.9 \times 10^{1}$ & $1.3 \times 10^{-8}$ & Ethyl benzene & $5.5 \times 10^{-1}$ & $1.7 \times 10^{-5}$ \\
\hline $\mathrm{Nb}-95$ & $1.0 \times 10^{-1}$ & $4.5 \times 10^{-11}$ & Toluene & $5.5 \times 10^{-1}$ & $1.7 \times 10^{-5}$ \\
\hline Tc-99 & $2.2 \times 10^{-2}$ & $9.5 \times 10^{-12}$ & Xylene & 1.2 & $3.8 \times 10^{-5}$ \\
\hline $\mathrm{Ru}-106$ & $2.3 \times 10^{3}$ & $1.0 \times 10^{-6}$ & Cadmium & $3.9 \times 10^{-1}$ & $1.7 \times 10^{-10}$ \\
\hline Rh-106 & $1.8 \times 10^{-1}$ & $8.0 \times 10^{-11}$ & Mercury & $2.5 \times 10^{-1}$ & $1.1 \times 10^{-10}$ \\
\hline $\mathrm{Sb}-125$ & $8.6 \times 10^{-1}$ & $3.8 \times 10^{-10}$ & Lead & $2.5 \times 10^{3}$ & $1.1 \times 10^{-6}$ \\
\hline Cs-134 & $1.3 \times 10^{2}$ & $5.8 \times 10^{-8}$ & & & \\
\hline Cs- 137 & $2.6 \times 10^{3}$ & $1.1 \times 10^{-6}$ & & & \\
\hline Ba-137m & $2.3 \times 10^{1}$ & $1.0 \times 10^{-8}$ & & & \\
\hline $\mathrm{Ce}-144$ & $5.5 \times 10^{2}$ & $2.4 \times 10^{-7}$ & & & \\
\hline Pr-144 & 2.2 & $9.5 \times 10^{-10}$ & & & \\
\hline Pm-147 & $2.9 \times 10^{4}$ & $1.3 \times 10^{-5}$ & & & \\
\hline Eu-154 & $2.2 \times 10^{-1}$ & $9.5 \times 10^{-11}$ & & & \\
\hline Eu-155 & $1.1 \times 10^{-1}$ & $4.8 \times 10^{-11}$ & & & \\
\hline Th-232 & $9.7 \times 10^{-6}$ & $4.3 \times 10^{-15}$ & & & \\
\hline U-233 & $3.4 \times 10^{-2}$ & $1.5 \times 10^{-11}$ & & & \\
\hline U-235 & $7.4 \times 10^{-2}$ & $3.3 \times 10^{-11}$ & & & \\
\hline U-236 & $6.9 \times 10^{-4}$ & $3.0 \times 10^{-13}$ & & & \\
\hline U-238 & $7.9 \times 10^{-3}$ & $3.5 \times 10^{-12}$ & & & \\
\hline $\mathrm{Np}-237$ & $7.4 \times 10^{-4}$ & $3.3 \times 10^{-13}$ & & & \\
\hline $\mathrm{Pu}-238$ & $1.1 \times 10^{1}$ & $4.8 \times 10^{-9}$ & & & \\
\hline Pu-239 & 4.3 & $1.9 \times 10^{-9}$ & & & \\
\hline $\mathrm{Pu}-240$ & $1.9 \times 10^{1}$ & $8.5 \times 10^{-9}$ & & & \\
\hline $\mathrm{Pu}-241$ & $1.1 \times 10^{4}$ & $4.8 \times 10^{-6}$ & & & \\
\hline
\end{tabular}


TABLE B.8 (Cont.)

\begin{tabular}{|c|c|c|c|c|c|}
\hline \multicolumn{3}{|c|}{ Radiological Profile } & \multicolumn{3}{|c|}{ Chemical Profile } \\
\hline Radionuclide & $\begin{array}{c}\text { Total } \\
\text { (Ci/yr) } \\
\end{array}$ & $\begin{array}{c}\text { Released } \\
(\mathrm{Ci} / \mathrm{yr})\end{array}$ & Contaminant & $\begin{array}{c}\text { Total } \\
(\mathrm{kg} / \mathrm{yr})\end{array}$ & $\begin{array}{c}\text { Released } \\
(\mathrm{kg} / \mathrm{yr})\end{array}$ \\
\hline \multicolumn{6}{|c|}{$\begin{array}{l}\text { Treatment Site: LANL } \\
\text { Volume: } 8.9 \mathrm{~m}^{3} / \mathrm{yr} \\
\end{array}$} \\
\hline Sr-90 & $2.1 \times 10^{2}$ & $1.3 \times 10^{-7}$ & Carbon tetrachloride & $4.0 \times 10^{-1}$ & $1.6 \times 10^{-5}$ \\
\hline $\mathrm{Y}-90$ & $2.1 \times 10^{2}$ & $1.3 \times 10^{-7}$ & Methyl chloroform & $6.0 \times 10^{-1}$ & $2.4 \times 10^{-5}$ \\
\hline Cs-137 & $1.6 \times 10^{2}$ & $9.7 \times 10^{-8}$ & Methylene chloride & 2.9 & $1.2 \times 10^{-4}$ \\
\hline $\mathrm{Ba}-137 \mathrm{~m}$ & $1.4 \times 10^{2}$ & $8.7 \times 10^{-8}$ & 1,1,2-trichloro-1,2,2- & 1.2 & $4.7 \times 10^{-5}$ \\
\hline Pm-147 & $1.6 \times 10^{2}$ & $9.7 \times 10^{-8}$ & trifluoroethane & & \\
\hline U-235 & $1.2 \times 10^{-3}$ & $7.0 \times 10^{-13}$ & Mercury & $1.3 \times 10^{-1}$ & $8.1 \times 10^{-11}$ \\
\hline U-238 & $1.1 \times 10^{-4}$ & $6.9 \times 10^{-14}$ & Lead & $1.5 \times 10^{1}$ & $8.9 \times 10^{-9}$ \\
\hline $\mathrm{Pu}-238$ & $8.2 \times 10^{-1}$ & $4.9 \times 10^{-10}$ & & & \\
\hline Pu-239 & 9.8 & $5.9 \times 10^{-9}$ & & & \\
\hline $\mathrm{Pu}-240$ & 3.1 & $1.9 \times 10^{-9}$ & & & \\
\hline $\mathrm{Pu}-241$ & $1.3 \times 10^{2}$ & $8.1 \times 10^{-8}$ & & & \\
\hline$\underline{\mathrm{Pu}-242}$ & $6.1 \times 10^{-4}$ & $3.7 \times 10^{-13}$ & & & \\
\hline \multicolumn{6}{|c|}{$\begin{array}{c}\text { Treatment Site: ORR } \\
\text { Volume: } 1.4 \times 10^{2} \mathrm{~m}^{3} / \mathrm{yr}\end{array}$} \\
\hline $\mathrm{Co}-60$ & $3.3 \times 10^{2}$ & $1.5 \times 10^{-7}$ & Carbon tetrachloride & $6.4 \times 10^{3}$ & $2.5 \times 10^{-1}$ \\
\hline Sr -90 & $1.1 \times 10^{4}$ & $5.1 \times 10^{-6}$ & Methyl chloroform & $1.9 \times 10^{4}$ & $7.6 \times 10^{-1}$ \\
\hline Cs-137 & $1.2 \times 10^{4}$ & $5.4 \times 10^{-6}$ & 1,1,2-trichloro-1,2,2- & $6.4 \times 10^{3}$ & $2.5 \times 10^{-1}$ \\
\hline Eu-152 & $1.6 \times 10^{3}$ & $7.0 \times 10^{-7}$ & trifluoroethane & & \\
\hline Eu-154 & $9.3 \times 10^{2}$ & $4.2 \times 10^{-7}$ & & & \\
\hline Th-232 & $3.7 \times 10^{-1}$ & $1.7 \times 10^{-10}$ & & & \\
\hline U-233 & $1.3 \times 10^{1}$ & $6.0 \times 10^{-9}$ & & & \\
\hline U-235 & $3.4 \times 10^{-5}$ & $1.5 \times 10^{-14}$ & & & \\
\hline $\mathrm{U}-238$ & $6.6 \times 10^{-5}$ & $3.0 \times 10^{-14}$ & & & \\
\hline $\mathrm{Np}-237$ & $1.3 \times 10^{-2}$ & $5.7 \times 10^{-12}$ & & & \\
\hline Pu-238 & $5.4 \times 10^{1}$ & $2.4 \times 10^{-8}$ & & & \\
\hline Pu-239 & $2.3 \times 10^{1}$ & $1.0 \times 10^{-8}$ & & & \\
\hline Pu-240 & $2.9 \times 10^{-2}$ & $1.3 \times 10^{-11}$ & & & \\
\hline Pu-241 & $7.4 \times 10^{-4}$ & $3.3 \times 10^{-13}$ & & & \\
\hline Am-241 & 4.4 & $1.9 \times 10^{-9}$ & & & \\
\hline $\mathrm{Cm}-244$ & $2.8 \times 10^{2}$ & $1.3 \times 10^{-7}$ & & & \\
\hline Cf-252 & 5.8 & $2.6 \times 10^{-9}$ & & & \\
\hline \multicolumn{6}{|c|}{$\begin{array}{l}\text { Treatment Site: SRS } \\
\text { Volume: } 7.1 \times 10^{-1} \mathrm{~m}^{3} / \mathrm{yr}\end{array}$} \\
\hline $\mathrm{H}-3$ & $2.93 \times 10^{-2}$ & $1.04 \times 10^{-4}$ & & & \\
\hline Sr -90 & $1.44 \times 10^{1}$ & $6.45 \times 10^{-9}$ & & & \\
\hline Cs- 137 & $1.44 \times 10^{1}$ & $6.46 \times 10^{-9}$ & & & \\
\hline Pm-147 & 2.81 & $1.26 \times 10^{-9}$ & & & \\
\hline $\mathrm{Pu}-238$ & $1.85 \times 10^{1}$ & $8.31 \times 10^{-9}$ & & & \\
\hline Pu-239 & $2.23 \times 10^{-2}$ & $9.99 \times 10^{-12}$ & & & \\
\hline Pu-240 & $1.06 \times 10^{-3}$ & $4.76 \times 10^{-13}$ & & & \\
\hline Am-241 & $1.43 \times 10^{-1}$ & $6.40 \times 10^{-11}$ & & & \\
\hline $\mathrm{Cm}-244$ & 9.83 & $4.41 \times 10^{-9}$ & & & \\
\hline
\end{tabular}


TABLE B.9 Projected Waste Loads and Release Profiles by Site in RH-TRUW Regionalized/Intermediate Treatment/Two Sites Alternative

\begin{tabular}{|c|c|c|c|c|c|}
\hline \multicolumn{3}{|c|}{ Radiological Profile } & \multicolumn{3}{|c|}{ Chemical Profile } \\
\hline Radionuclide & $\begin{array}{l}\text { Total } \\
(\mathrm{Ci} / \mathrm{yr})\end{array}$ & $\begin{array}{l}\text { Released } \\
(\mathrm{Ci} / \mathrm{yr})\end{array}$ & Contaminant & $\begin{array}{c}\text { Total } \\
(\mathrm{kg} / \mathrm{yr})\end{array}$ & $\begin{array}{c}\text { Released } \\
(\mathrm{kg} / \mathrm{yr})\end{array}$ \\
\hline \multicolumn{6}{|c|}{$\begin{array}{l}\text { Treatment Site: Hanford } \\
\text { Volume: } 6.3 \times 10^{2} \mathrm{~m}^{3} / \mathrm{yr}\end{array}$} \\
\hline $\mathrm{H}-3$ & $3.03 \times 10^{-2}$ & $3.81 \times 10^{-4}$ & Carbon tetrachloride & 9.38 & $4.64 \times 10^{-4}$ \\
\hline $\mathrm{Fe}-55$ & $1.26 \times 10^{-1}$ & $9.06 \times 10^{-11}$ & Methyl alcohol & $1.87 \times 10^{-2}$ & $7.50 \times 10^{-7}$ \\
\hline Co-60 & $4.44 \times 10^{3}$ & $3.48 \times 10^{-6}$ & Butanol & $1.21 \times 10^{-2}$ & $4.84 \times 10^{-7}$ \\
\hline $\mathrm{Ni}-63$ & $7.42 \times 10^{-1}$ & $5.32 \times 10^{-10}$ & Methyl chloroform & $2.32 \times 10^{1}$ & $1.15 \times 10^{-3}$ \\
\hline $\mathrm{Kr}-85$ & 1.26 & $1.59 \times 10^{-2}$ & Methylene chloride & $1.45 \times 10^{2}$ & $7.19 \times 10^{-3}$ \\
\hline Sr-90 & $8.55 \times 10^{4}$ & $6.70 \times 10^{-5}$ & 1,1,2-trichloro-1,2,2- & $6.37 \times 10^{1}$ & $3.16 \times 10^{-3}$ \\
\hline Tc-99 & $2.34 \times 10^{-3}$ & $1.79 \times 10^{-12}$ & trifluoroethane & & \\
\hline Sn-121m & $2.68 \times 10^{-3}$ & $2.05 \times 10^{-12}$ & Ethyl benzene & $1.70 \times 10^{-2}$ & $3.64 \times 10^{-7}$ \\
\hline $\mathrm{Sb}-125$ & $8.92 \times 10^{-1}$ & $6.74 \times 10^{-10}$ & Toluene & $1.70 \times 10^{-2}$ & $3.64 \times 10^{-7}$ \\
\hline Cs-134 & $1.14 \times 10^{1}$ & $8.18 \times 10^{-9}$ & Xylene & $3.75 \times 10^{-2}$ & $8.01 \times 10^{-7}$ \\
\hline Cs-137 & $9.24 \times 10^{4}$ & $7.24 \times 10^{-5}$ & Cadmium & $1.21 \times 10^{-2}$ & $5.31 \times 10^{-12}$ \\
\hline Pm-147 & 5.93 & $4.39 \times 10^{-9}$ & Mercury & 7.14 & $5.60 \times 10^{-9}$ \\
\hline $\mathrm{Sm}-151$ & $1.59 \times 10^{-1}$ & $1.21 \times 10^{-10}$ & Lead & $6.66 \times 10^{4}$ & $5.22 \times 10^{-5}$ \\
\hline $\mathrm{Eu}-152$ & $2.41 \times 10^{-2}$ & $1.73 \times 10^{-11}$ & & & \\
\hline Eu-154 & $1.76 \times 10^{-1}$ & $1.27 \times 10^{-10}$ & & & \\
\hline Eu-155 & $5.06 \times 10^{-1}$ & $3.85 \times 10^{-10}$ & & & \\
\hline $\mathrm{U}-233$ & 5.55 & $4.34 \times 10^{-9}$ & & & \\
\hline $\mathrm{U}-234$ & $1.71 \times 10^{1}$ & $1.34 \times 10^{-8}$ & & & \\
\hline $\mathrm{U}-235$ & $2.16 \times 10^{-3}$ & $1.65 \times 10^{-12}$ & & & \\
\hline Pu-238 & $6.29 \times 10^{2}$ & $4.92 \times 10^{-7}$ & & & \\
\hline Pu-239 & $4.44 \times 10^{3}$ & $3.48 \times 10^{-6}$ & & & \\
\hline $\mathrm{Pu}-240$ & $2.20 \times 10^{3}$ & $1.72 \times 10^{-6}$ & & & \\
\hline $\mathrm{Pu}-241$ & $6.15 \times 10^{4}$ & $4.82 \times 10^{-5}$ & & & \\
\hline$A m-241$ & $2.56 \times 10^{3}$ & $2.00 \times 10^{-6}$ & & & \\
\hline $\mathrm{Cm}-243$ & $3.08 \times 10^{-3}$ & $2.21 \times 10^{-12}$ & & & \\
\hline $\mathrm{Cm}-244$ & $2.04 \times 10^{-2}$ & $1.46 \times 10^{-11}$ & & & \\
\hline
\end{tabular}


TABLE B.9 (Cont.)

\begin{tabular}{|c|c|c|c|c|c|}
\hline \multicolumn{3}{|c|}{ Radiological Profile } & \multicolumn{3}{|c|}{ Chemical Profile } \\
\hline Radionuclide & $\begin{array}{c}\text { Total } \\
(\mathrm{Ci} / \mathrm{yr}) \\
\end{array}$ & $\begin{array}{c}\text { Released } \\
(\mathrm{Ci} / \mathrm{yr})\end{array}$ & Contaminant & $\begin{array}{c}\text { Total } \\
(\mathrm{kg} / \mathrm{yr})\end{array}$ & $\begin{array}{c}\text { Released } \\
(\mathrm{kg} / \mathrm{yr})\end{array}$ \\
\hline \multicolumn{6}{|c|}{$\begin{array}{c}\text { Treatment Site: ORR } \\
\text { Volume: } 1.8 \times 10^{2} \mathrm{~m}^{3} / \mathrm{yr}\end{array}$} \\
\hline $\mathrm{Co}-60$ & $3.3 \times 10^{2}$ & $1.5 \times 10^{-7}$ & Carbon tetrachloride & $6.4 \times 10^{3}$ & $2.5 \times 10^{-1}$ \\
\hline St -90 & $1.1 \times 10^{4}$ & $5.1 \times 10^{-6}$ & Methyl chloroform & $1.9 \times 10^{4}$ & $7.6 \times 10^{-1}$ \\
\hline Cs-137 & $1.2 \times 10^{4}$ & $5.7 \times 10^{-6}$ & Methylene chloride & 2.9 & $1.2 \times 10^{-4}$ \\
\hline $\mathrm{Eu}-152$ & $1.6 \times 10^{3}$ & $7.0 \times 10^{-7}$ & 1,1,2-trichloro-1,2,2- & $6.4 \times 10^{3}$ & $2.5 \times 10^{-1}$ \\
\hline $\mathrm{Eu}-154$ & $9.3 \times 10^{2}$ & $4.2 \times 10^{-7}$ & trifluoroethane & & \\
\hline Th-232 & $3.7 \times 10^{-1}$ & $1.7 \times 10^{-10}$ & Lead & 7.5 & $5.7 \times 10^{-9}$ \\
\hline U-233 & $1.3 \times 10^{1}$ & $6.0 \times 10^{-9}$ & & & \\
\hline U-235 & $3.4 \times 10^{-5}$ & $1.5 \times 10^{-14}$ & & & \\
\hline U-238 & 3.7 & $2.8 \times 10^{-9}$ & & & \\
\hline Np-237 & $1.3 \times 10^{-2}$ & $5.7 \times 10^{-12}$ & & & \\
\hline Pu-238 & $5.4 \times 10^{1}$ & $2.4 \times 10^{-8}$ & & & \\
\hline Pu-239 & $2.8 \times 10^{1}$ & $1.4 \times 10^{-8}$ & & & \\
\hline $\mathrm{Pu}-240$ & 3.7 & $2.8 \times 10^{-9}$ & & & \\
\hline Pu-241 & $4.8 \times 10^{1}$ & $3.6 \times 10^{-8}$ & & & \\
\hline Am-241 & 4.4 & $1.9 \times 10^{-9}$ & & & \\
\hline $\mathrm{Cm}-244$ & $2.8 \times 10^{2}$ & $1.3 \times 10^{-7}$ & & & \\
\hline Cf-252 & 5.8 & $2.6 \times 10^{-9}$ & & & \\
\hline
\end{tabular}


TABLE B.10 Projected Waste Loads and Release Profiles by Site in RH-TRUW Regionalized/Treatment to LDRs/Two Sites Alternative

\begin{tabular}{|c|c|c|c|c|c|}
\hline \multicolumn{3}{|c|}{ Radiological Profile } & \multicolumn{3}{|c|}{ Chemical Profile } \\
\hline Radionuclide & $\begin{array}{r}\text { Total } \\
(\mathrm{Ci} / \mathrm{yr}) \\
\end{array}$ & $\begin{array}{c}\text { Released } \\
(\mathrm{Ci} / \mathrm{yr}) \\
\end{array}$ & Contaminant & $\begin{array}{c}\text { Total } \\
(\mathrm{kg} / \mathrm{yr})\end{array}$ & $\begin{array}{c}\text { Released } \\
(\mathrm{kg} / \mathrm{yr})\end{array}$ \\
\hline \multicolumn{6}{|c|}{$\begin{array}{l}\text { Treatment Site: Hanford } \\
\text { Volume: } 6.3 \times 10^{2} \mathrm{~m}^{3} / \mathrm{yr}\end{array}$} \\
\hline $\mathrm{H}-3$ & $3.03 \times 10^{-2}$ & $6.24 \times 10^{-3}$ & Carbon tetrachloride & 9.38 & $4.53 \times 10^{-4}$ \\
\hline $\mathrm{Fe}-55$ & $1.26 \times 10^{-1}$ & $5.40 \times 10^{-7}$ & Methyl alcohol & $1.87 \times 10^{-2}$ & $1.09 \times 10^{-7}$ \\
\hline Co- 60 & $4.44 \times 10^{3}$ & $3.42 \times 10^{-5}$ & Butanol & $1.21 \times 10^{-2}$ & $1.22 \times 10^{-7}$ \\
\hline $\mathrm{Ni}-63$ & $7.42 \times 10^{-1}$ & $3.17 \times 10^{-6}$ & Methyl chloroform & $2.32 \times 10^{1}$ & $1.12 \times 10^{-3}$ \\
\hline $\mathrm{Kr}-85$ & 1.26 & $2.60 \times 10^{-1}$ & Methylene chloride & $1.45 \times 10^{2}$ & $7.03 \times 10^{-3}$ \\
\hline Sr-90 & $8.55 \times 10^{4}$ & $2.07 \times 10^{-3}$ & 1,1,2-trichloro-1,2,2- & $6.37 \times 10^{1}$ & $3.08 \times 10^{-3}$ \\
\hline Tc-99 & $2.34 \times 10^{-3}$ & $3.60 \times 10^{-8}$ & trifluoroethane & & \\
\hline $\mathrm{Sn}-121 \mathrm{~m}$ & $2.68 \times 10^{-3}$ & $4.12 \times 10^{-8}$ & Ethyl benzene & $1.70 \times 10^{-2}$ & $1.82 \times 10^{-7}$ \\
\hline $\mathrm{Sb}-125$ & $8.92 \times 10^{-1}$ & $1.14 \times 10^{-5}$ & Toluene & $1.70 \times 10^{-2}$ & $1.82 \times 10^{-7}$ \\
\hline Cs-134 & $1.14 \times 10^{1}$ & $4.88 \times 10^{-5}$ & Xylene & $3.75 \times 10^{-2}$ & $4.00 \times 10^{-7}$ \\
\hline Cs-137 & $9.24 \times 10^{4}$ & $2.31 \times 10^{-3}$ & Cadmium & $1.21 \times 10^{-2}$ & $1.38 \times 10^{-8}$ \\
\hline Pm-147 & 5.93 & $5.61 \times 10^{-5}$ & Mercury & 7.14 & $5.64 \times 10^{-9}$ \\
\hline $\mathrm{Sm}-151$ & $1.59 \times 10^{-1}$ & $2.26 \times 10^{-6}$ & Lead & $6.66 \times 10^{4}$ & $5.56 \times 10^{-5}$ \\
\hline $\mathrm{Eu}-152$ & $2.41 \times 10^{-2}$ & $1.03 \times 10^{-7}$ & & & \\
\hline Eu-154 & $1.76 \times 10^{-1}$ & $8.48 \times 10^{-7}$ & & & \\
\hline$E_{U-155}$ & $5.06 \times 10^{-1}$ & $6.99 \times 10^{-6}$ & & & \\
\hline U-233 & 5.55 & $3.59 \times 10^{-7}$ & & & \\
\hline $\mathrm{U}-234$ & $1.71 \times 10^{1}$ & $1.50 \times 10^{-7}$ & & & \\
\hline U-235 & $2.16 \times 10^{-3}$ & $3.31 \times 10^{-8}$ & & & \\
\hline Pu-238 & $6.29 \times 10^{2}$ & $7.04 \times 10^{-5}$ & & & \\
\hline Pu-239 & $4.44 \times 10^{3}$ & $3.81 \times 10^{-4}$ & & & \\
\hline $\mathrm{Pu}-240$ & $2.20 \times 10^{3}$ & $2.42 \times 10^{-5}$ & & & \\
\hline $\mathrm{Pu}-241$ & $6.15 \times 10^{4}$ & $9.22 \times 10^{-5}$ & & & \\
\hline Am-241 & $2.56 \times 10^{3}$ & $4.45 \times 10^{-5}$ & & & \\
\hline $\mathrm{Cm}-243$ & $3.08 \times 10^{-3}$ & $1.32 \times 10^{-8}$ & & & \\
\hline $\mathrm{Cm}-244$ & $2.04 \times 10^{-2}$ & $8.72 \times 10^{-8}$ & & & \\
\hline
\end{tabular}


TABLE B.10 (Cont.)

\begin{tabular}{|c|c|c|c|c|c|}
\hline \multicolumn{3}{|c|}{ Radiological Profile } & \multicolumn{3}{|c|}{ Chemical Profile } \\
\hline Radionuclide & $\begin{array}{c}\text { Total } \\
(\mathrm{Ci} / \mathrm{yr}) \\
\end{array}$ & $\begin{array}{c}\text { Released } \\
(\mathrm{Ci} / \mathrm{yr})\end{array}$ & Contaminant & $\begin{array}{c}\text { Total } \\
(\mathrm{kg} / \mathrm{yr})\end{array}$ & $\begin{array}{c}\text { Released } \\
(\mathrm{kg} / \mathrm{yr})\end{array}$ \\
\hline \multicolumn{6}{|c|}{$\begin{array}{c}\text { Treatment Site: ORR } \\
\text { Volume: } 1.8 \times 10^{2} \mathrm{~m}^{3} / \mathrm{yr}\end{array}$} \\
\hline $\mathrm{Co}-60$ & $3.3 \times 10^{2}$ & $8.3 \times 10^{-3}$ & Carbon tetrachloride & $6.4 \times 10^{3}$ & $1.8 \times 10^{-1}$ \\
\hline Sr-90 & $1.1 \times 10^{4}$ & $2.9 \times 10^{-1}$ & Methyl chloroform & $1.9 \times 10^{4}$ & $5.4 \times 10^{-1}$ \\
\hline $\mathrm{Cs}-137$ & $1.2 \times 10^{4}$ & $3.1 \times 10^{-1}$ & Methylene chloride & 2.9 & $3.1 \times 10^{-5}$ \\
\hline Eu-152 & $1.6 \times 10^{3}$ & $3.9 \times 10^{-2}$ & 1,1,2-trichloro-1,2,2- & $6.4 \times 10^{3}$ & $1.8 \times 10^{-1}$ \\
\hline Eu-154 & $9.3 \times 10^{2}$ & $2.4 \times 10^{-2}$ & trifluoroethane & & \\
\hline Th-232 & $3.7 \times 10^{-1}$ & $9.3 \times 10^{-6}$ & Lead & 7.5 & $1.8 \times 10^{-4}$ \\
\hline U-233 & $1.3 \times 10^{1}$ & $3.4 \times 10^{-4}$ & & & \\
\hline U-235 & $3.4 \times 10^{-5}$ & $8.6 \times 10^{-10}$ & & & \\
\hline U-238 & 3.7 & $8.9 \times 10^{-5}$ & & & \\
\hline Np-237 & $1.3 \times 10^{-2}$ & $3.2 \times 10^{-7}$ & & & \\
\hline Pu-238 & $5.4 \times 10^{1}$ & $1.4 \times 10^{-3}$ & & & \\
\hline Pu-239 & $2.8 \times 10^{1}$ & $6.9 \times 10^{-4}$ & & & \\
\hline $\mathrm{Pu}-240$ & 3.8 & $9.0 \times 10^{-5}$ & & & \\
\hline Pu-241 & $4.8 \times 10^{1}$ & $1.1 \times 10^{-3}$ & & & \\
\hline Am-241 & 4.4 & $1.1 \times 10^{-4}$ & & & \\
\hline $\mathrm{Cm}-244$ & $2.8 \times 10^{2}$ & $7.2 \times 10^{-3}$ & & & \\
\hline Cf -252 & 5.8 & $1.5 \times 10^{-4}$ & & & \\
\hline
\end{tabular}


C-1

APPENDIX C:

UNRESOLVED ISSUES 
C-2 


\section{C-3}

\section{APPENDIX C: \\ UNRESOLVED ISSUES}

Three issues that remain to be resolved are as follows.

1. The release fractions for the various treatment technologies are inconsistent with respect to each other and with respect to the generic facility designs applied in the WM PEIS. Further research is necessary to assure this consistency.

2. Treatment alternatives for long-term safe storage of transuranic waste need to be included.

3. The concentrations of hazardous constituents for TRUW were based on waste-generating processes at RFETS. Given the many ways that TRUW can be generated, this application can be considered to be highly conservative. More recent data concerning the chemical composition of TRUW is required for all major TRUW sites. 